\title{
Growth in Punctuation and Capitalization Abilities
}

James E. Goodman

College of William \& Mary - School of Education

Follow this and additional works at: https://scholarworks.wm.edu/etd

Part of the Language and Literacy Education Commons

\section{Recommended Citation}

Goodman, James E., "Growth in Punctuation and Capitalization Abilities" (1931). Dissertations, Theses, and Masters Projects. Paper 1539272128.

https://dx.doi.org/doi:10.25774/w4-ppq7-x262

This Thesis is brought to you for free and open access by the Theses, Dissertations, \& Master Projects at W\&M ScholarWorks. It has been accepted for inclusion in Dissertations, Theses, and Masters Projects by an authorized administrator of W\&M ScholarWorks. For more information, please contact scholarworks@wm.edu. 


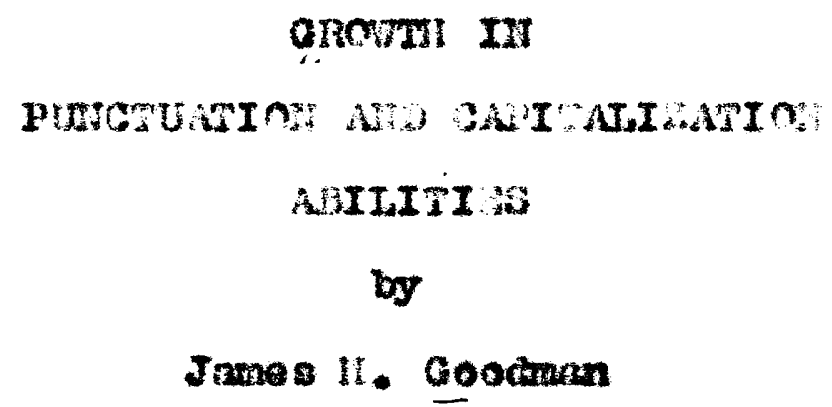




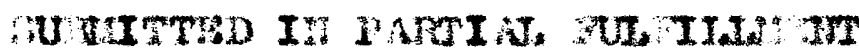

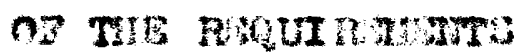

$$
\text { or }
$$

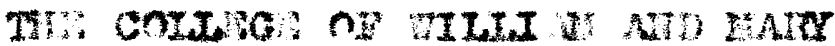

for the derines of

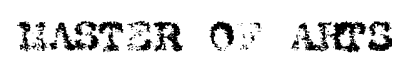

1932 


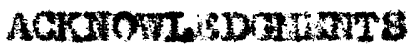

This study was undertaken the euggestion of profeaver I. Paul Loonand, Colloge of 14211 an and 1axy. I wah to exprees w gratitude for ht and

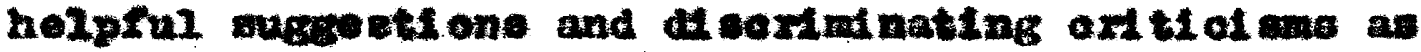
wall for his buotaling enthust aso and generous cexrioen as chat xman of ay degree vormittee. I m. albo, Indebted to Protennox Kremer $J$. lloke and to Profeneor ffchand L. Hoxten, Whe also served on yo degree combtted. for thei $x$ invigorating enocuragemont.

$$
\text { J.H. } \text { a. }_{0}
$$


Guptex I

The Prolnen and 1te uternture

Stenteflanoe of the proble

me 2lsormtune of the sield

rethede of teoting punetuati on and captivitation abilities

Buml ograriay

Pase

$\mathbf{2}$

2

8

7

Cuaptar II

rateghals and procodmrae

8

Tro mosuring inotrument

The puplis tented 10

Pximplates 2

ander IXI

The Dampte

Cepiterization

14

Punotwati ax

15

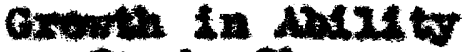

25

arade tive

Qrant tive and elemen

16

29

Grate: fro and at 37

orados atx and moren. 40

brinioe cowon and of ht 40

Grodo dint and nine 45

Grace ato and tan is

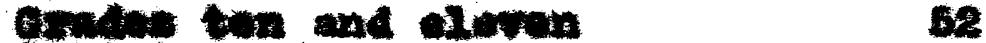

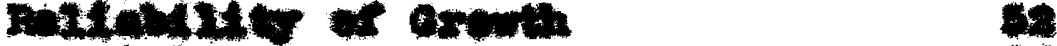

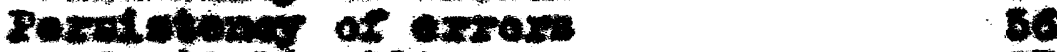

Gaptukinate of

Drengtuatien.. 60

Die ond 60

The portad

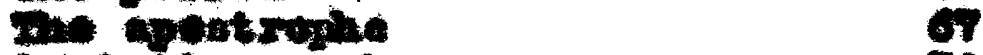

Genctien naper 70

onottica matiol 73

The eaten 73

We caderen 73

Cemestmag of exror ravidinge 70

Drmaxy of the rindinge 82

Appenatx 
Itet of Tables and Graphe

\begin{tabular}{|c|c|c|c|c|c|c|}
\hline Table & & Page & $a x$ & & & Pag \\
\hline $\mathbf{A}$ & $-\quad-$ & 17 & 1 & - & - & 2 \\
\hline$B$ & $-\quad-$ & 18 & 2 & - & - & 23 \\
\hline 1 & $-\quad-$ & 20 & 3 & - & - & 25 \\
\hline 2 & $-\quad-$ & 22 & 4 & - & - & 27 \\
\hline 3 & $-\quad-$ & 24 & 5 & $=$ & - & 29 \\
\hline 4 & $-\quad-$ & 20 & 6 & - & - & 32 \\
\hline 5 & $-\quad-$ & 28 & 7 & - & - & 35 \\
\hline 6 & $-\quad-$ & 30 & $\mathbf{8}$ & - & - & 36 \\
\hline 7 & $-\quad-$ & 32 & 9 & - & - & 30 \\
\hline 8 & $-\quad-$ & 35 & 20 & - & - & 48 \\
\hline 9 & $-\quad-$ & 38 & 11 & - & - & 4 \\
\hline 10 & $-\quad-$ & 42 & 22 & - & - & 47 \\
\hline 12 & $-\quad-$ & 43 & 13 & - & - & 49 \\
\hline 12 & $-\quad-$ & 46 & 24 & - & - & $\mathbf{5 1}$ \\
\hline 13 & $=-$ & 48 & $\mathbf{1 5}$ & - & $=$ & 69 \\
\hline 14 & $-\quad-$ & 50 & 26 & - & - & 62 \\
\hline$c$ & $-\quad-$ & 54 & 27 & - & - & 65 \\
\hline D & $-\quad-$ & 58 & 28 & - & - & 69 \\
\hline 35 & $-\quad-$ & 58 & 29 & - & - & 72 \\
\hline 16 & $-\quad-$ & 61 & 20 & - & - & 75 \\
\hline 37 & $-\quad-$ & 64 & & & & \\
\hline 28 & $-\quad-$ & 68 & & & & \\
\hline 29 & $-\quad-$ & 72 & & & & \\
\hline 20 & $-\quad-$ & 74 & & & & \\
\hline $\mathbf{z}$ & $-\quad-$ & 78 & & & & \\
\hline $\mathbf{z}$ & - & 80 & & & & \\
\hline
\end{tabular}


Capter I

me probre and $x+$ Itematus:

\section{Therentes}

This etudy endenvore to doternd we:

1. The xulative erowth in abluty to punotuate and eapt tallze oexwoty from crade to crado.

2. The rolative peral atenes of errese in punotum atton and cepteristation wade by pupize in owh grade from the firth to the oleventh induatre.

3. buether or not the rwaling oxder of exrow mado by puplle in ates of punotuatl on and

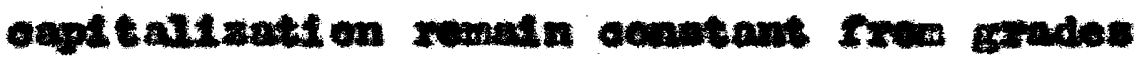
Aro to eleven inolugtre.

\section{Sintalenes of the Brebrem}

The inportance of this otud 14 es in 1 to attanpt to Indseate the relative perventage of exrexe mado in

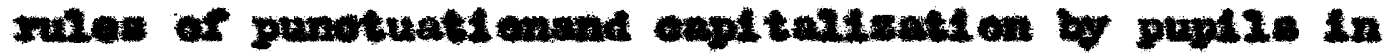

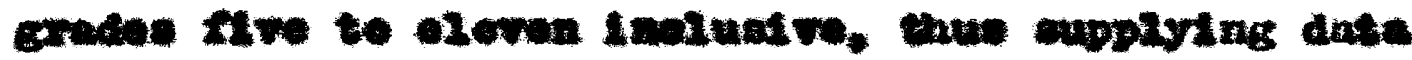

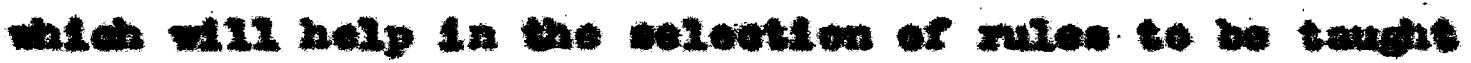

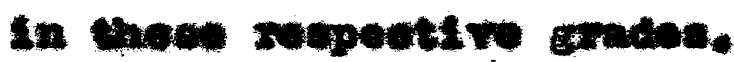

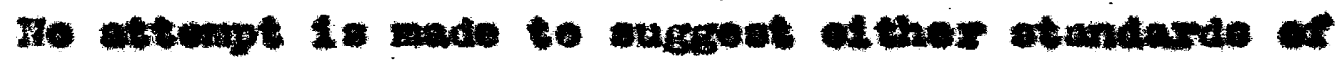

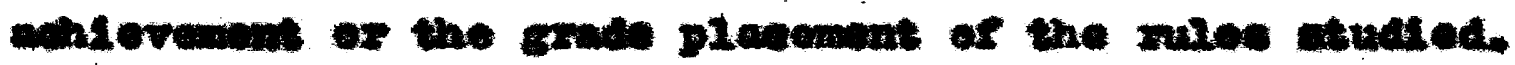

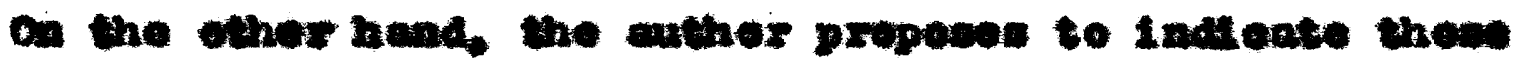

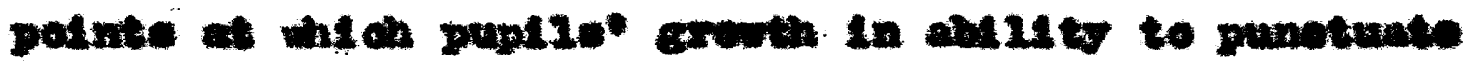

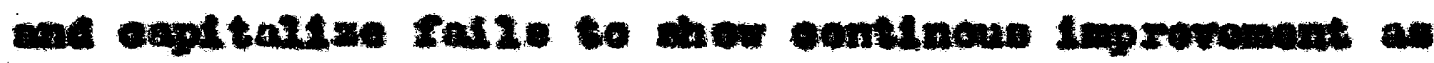


wall at these points at wh ch mavtery is approached. moes findinge mor be uned by the reader to mugeat a grade plademont of the rules otudied.

The importanoe of a deflinte attaok on this prob-

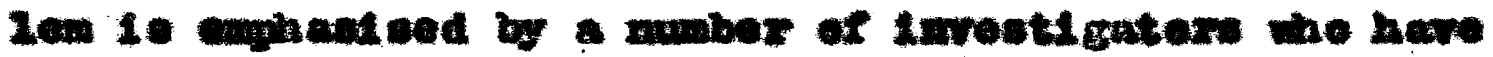

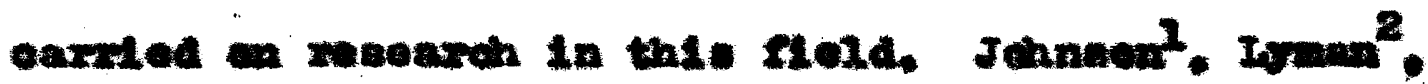

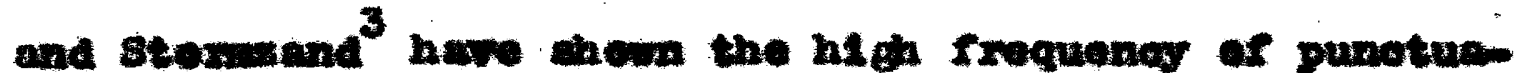

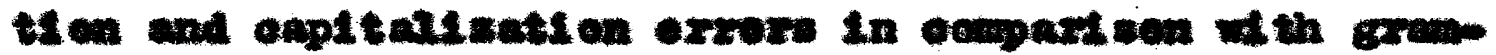

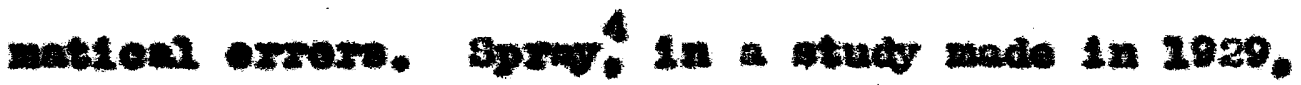
carties we of th the statement that munotuati on and eaptallzati on exrore wooount for 70.6 peroent or all errore made". In exdinar alenervem ceupeat ti one ex children in gredes three to nine inoluetre.

\section{Th r retenture of the gine}

Inwereus etudiea have been made in the Iteld of punotuati on and oapttalizati on. The chier purpose or theme atudse has been te doterzal no the frequency or axrex In the stementaxy. Junt or and pent or hich scheol.

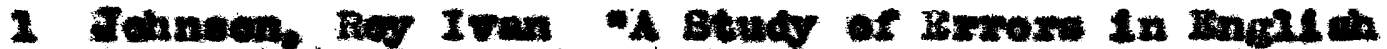

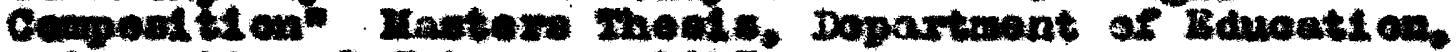
Unt verat ty of Chseage. 2027.

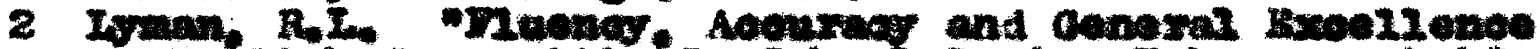

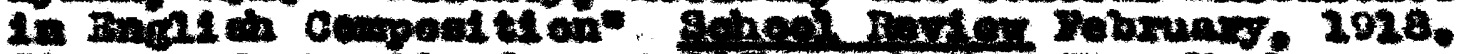

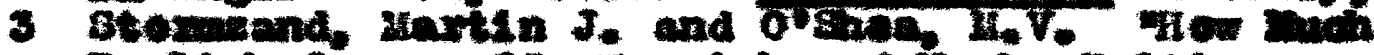

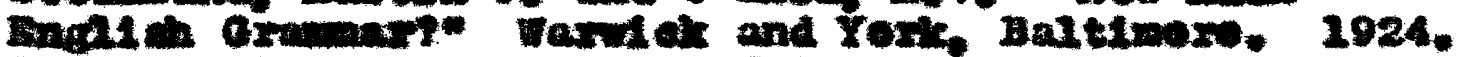

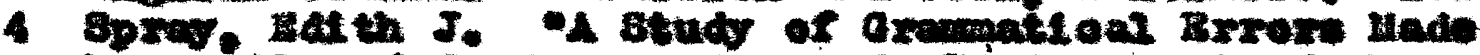
b Puptze of arades 3, 4, 5, 6,7, 8, and 9 of the

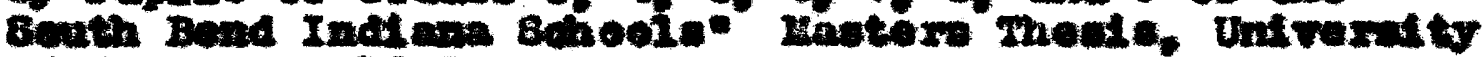
a chlease, 1029 . 
and auong univeraty otudente. Those related most olesely to this atudy are Ilsted at the ond of this chapter. Their moat important findinge mas bo oxmanlaed as ronzow.

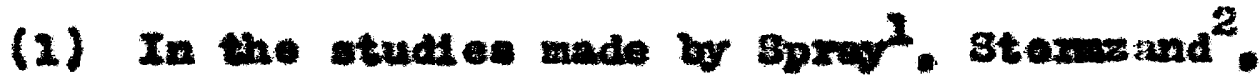

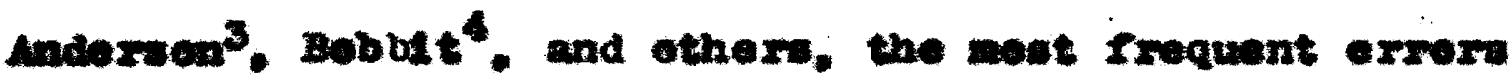
In watten expresal on were found in punotuats on and capitarization. Inose otudles waro based upon Impenticatiens fro the thi rd exade of the elementary wohool. through the uni verat ty and into adurt 1 ire.

(2) The study made by $J_{\text {Chnoon }}^{5}$ wecus to indieate

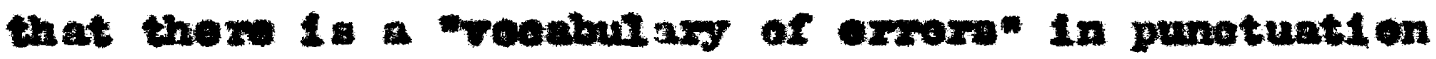

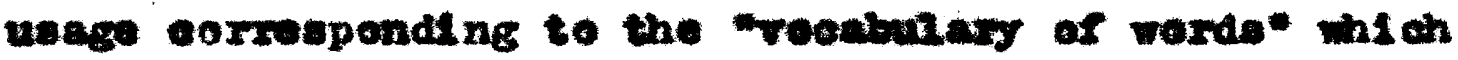
pup11. nos in weltten exprees ea.

(3) In General, It appeare that orrox in copttal1zati on are almost as frequent as exrers in pundtuti an. A oareful weareh through the investigati ons of

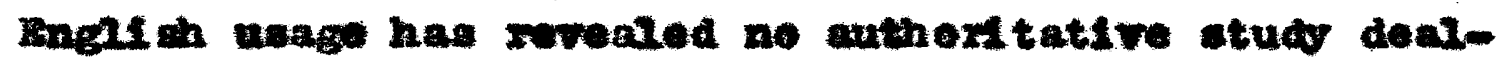
Ing wth punotuati on and oapltalzati on errour ruse by

1 Ima.

2 ibit.

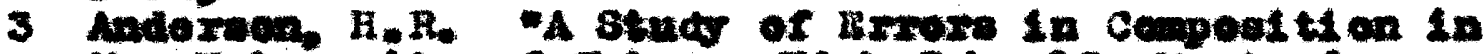

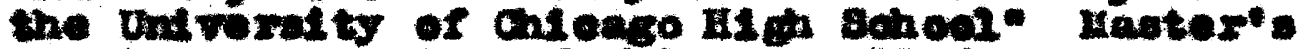

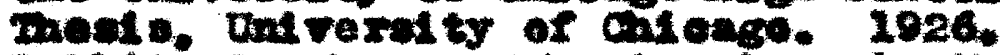

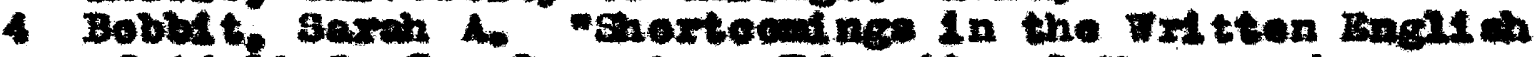

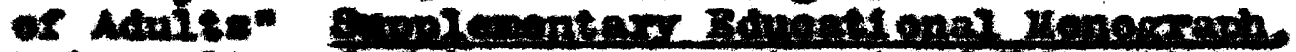

5 18d.

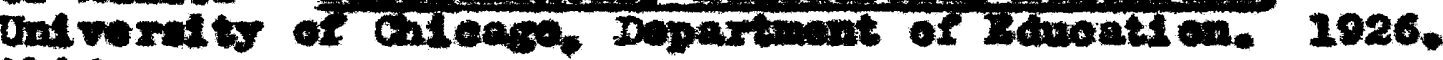
atos. 
Inie and grade by grade.

Symonds and Iee' studied a Ilatted number of punotuati on and eapt tallati on errors in oempost ti on arranged of grades on the band of their rating on the H121eges Compolt on Soule. In a later chapter the wevite of this atud are oentrated of th the findingo of the propent study.

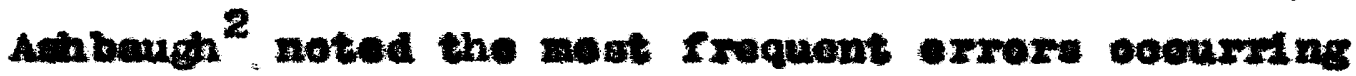
in the "unstuded watinge" of hich cohool puptis. He exant ned Ietters sont through the mals by Jund ex and eent ox his ochool puptie to thetr friende. He ranked the seven moes poral atent exroxo. A cempariben w th the ramke indieated by the preeent otudy is mown in a Iater enapter.

Leonard ${ }^{3}$ atudied the punotuati on and eapt tallsati on errexs made in a peleot group of ef chth and minth grade pup12. The proofreading tegt conotruoted by Ieonard for uee in his atudy is ueed for deteratinting the rindinge of the present otudy. Leennid's Indinge are cempared Ath the reaulte of the present atudy in a leter chapter. The wermbelming evidenee of a unt versal defiofeney In ability to punotuate and expltallze oorzeotiy demon-

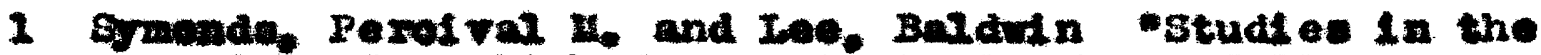

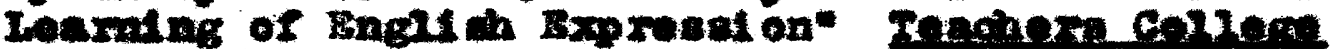
Far. Vo. 30, P. 460-464; 687-602.

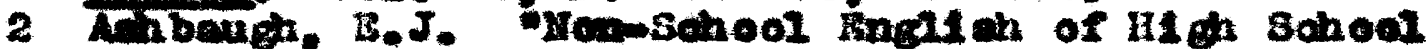

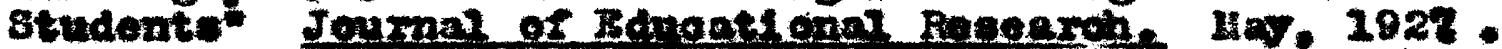

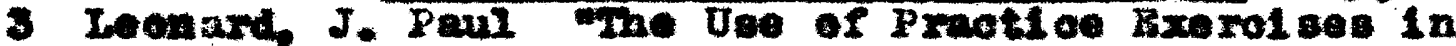
the renoht ng of Capltall zati on and punotuati en *

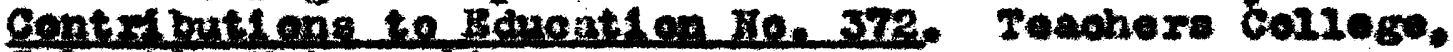
corrina unterats. 
atrates of th inoreabing forve the need for impestlenti and wion was Ioed to Improved learning in this branch of Haglen venge.

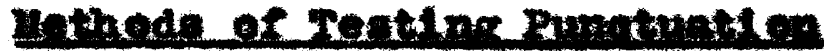 end contentention andition.}

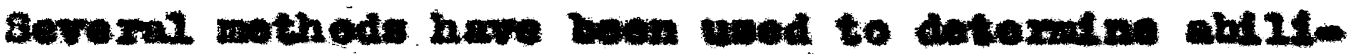

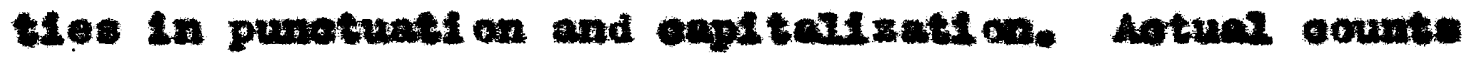
of the frequency of exrers in the witten wert of puptie

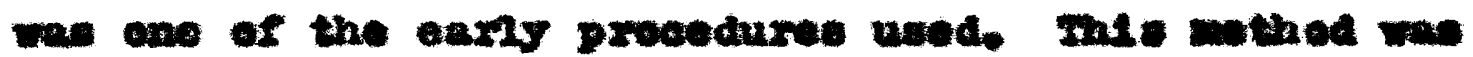

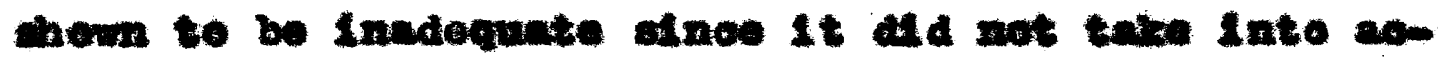
eount the nuber of oppertumiltes for exror.

Iater, the reinti on betwaen the aumber of errore and the muber of opportunits es for exrop in the vitten

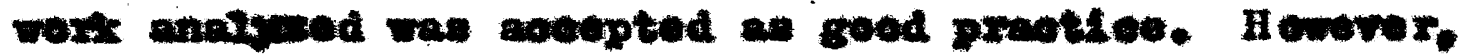
som oportumites for errox appoared infraquently.

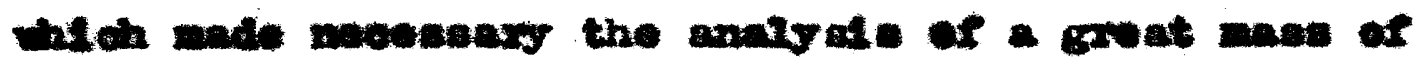

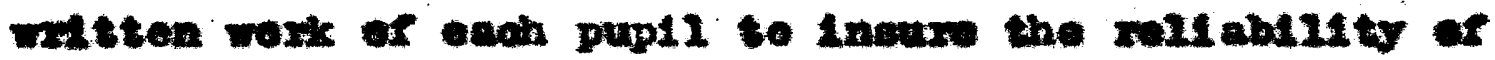
the reaulte with each type of usare.

Stmultanoous wth this dewel ogment of technique

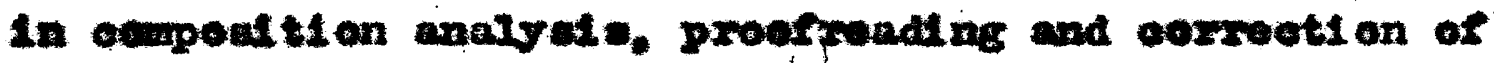
exror ceete ware brought into ves as inesruments or

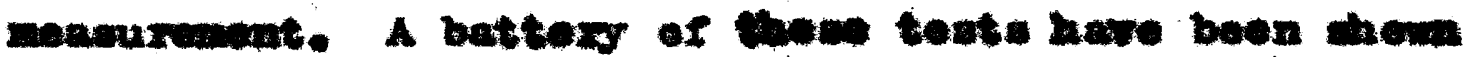

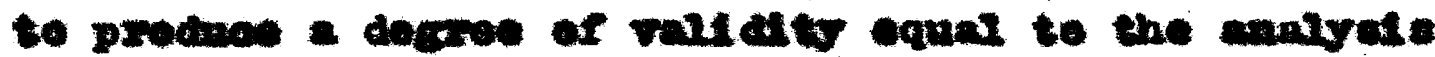

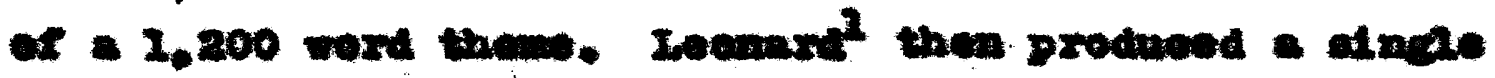

2 inda. 
test winch equaled in validity the results of the battery of teats fomeriy omployed. The present study is based on the reaults of the Leonard test. This test. wilion utilizes the nost advinoed teaniques of measurarant, 1 is dosoribed in cotall in the following oh apter. 


\section{Nomingraph}

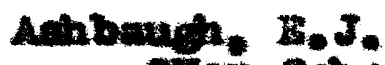

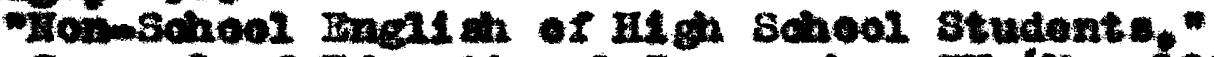

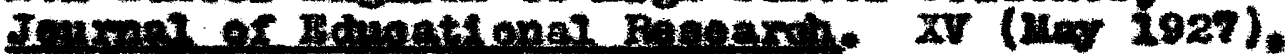
Whose.

Debrat th, samis a.

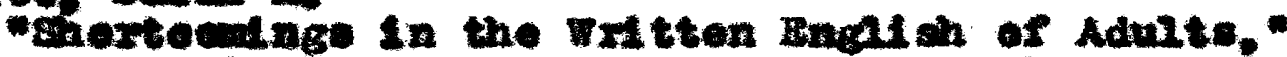

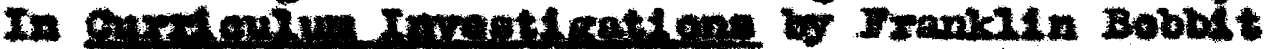

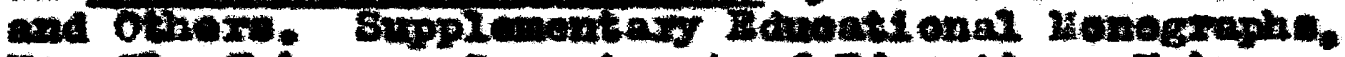

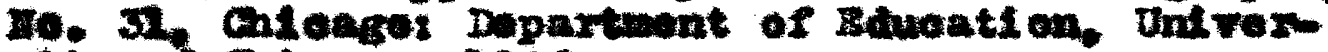
aty of Giterse, 2026.

Brexp, thomen $I_{\text {. }}$

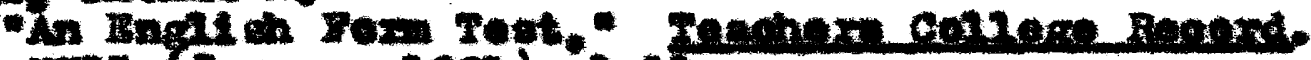
XxI (Tamers 292). $2-11$.

charcerw. Vor.

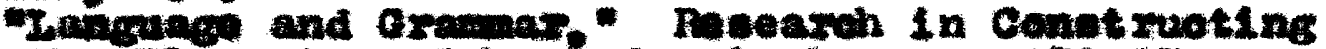

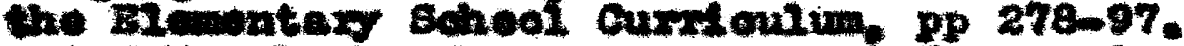

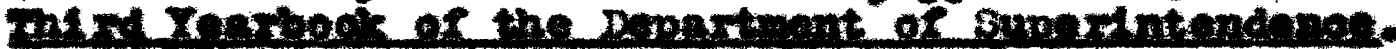

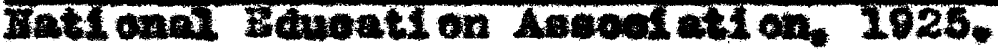

Jennoens Rey Tran.

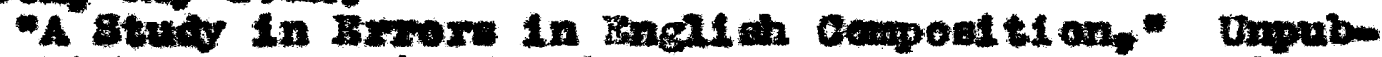

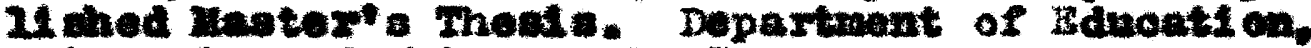
Untrexat ty of culase. 1917.

Jennane Roy Tran.

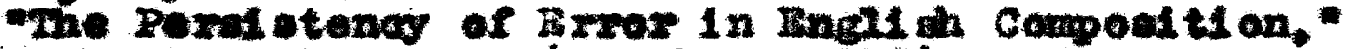

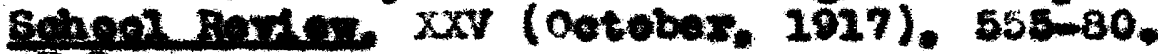

$x=2,10$

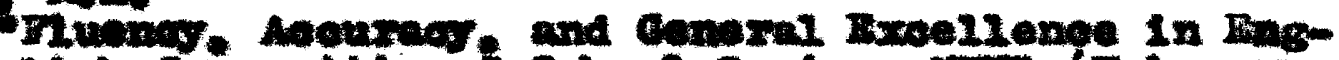

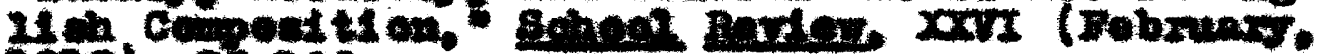

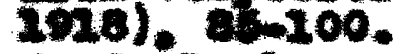

Lamard. J. Dant.

otte of Pragti es Bramat nes in the reaching of

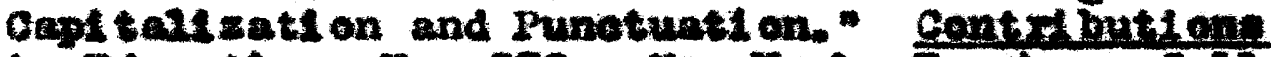

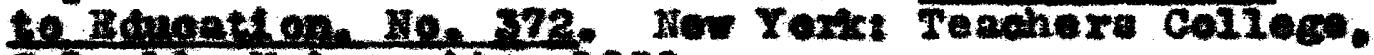

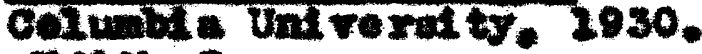

Qpras, Edatis.

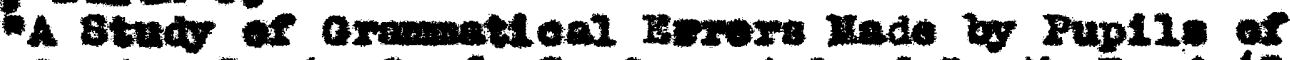
Grudes 3, 4, 5, 6, 7,6 , and 9 of Bouth Bend (Ind -

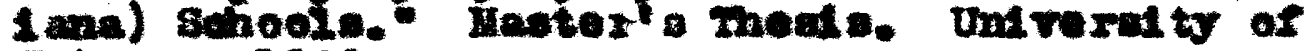
Chisago, 2929.

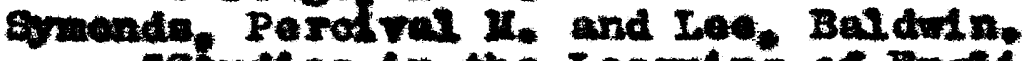

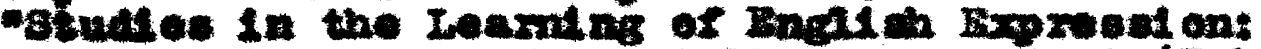

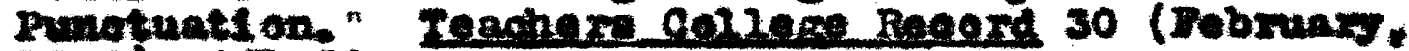
2020), 40-60.

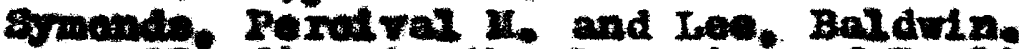

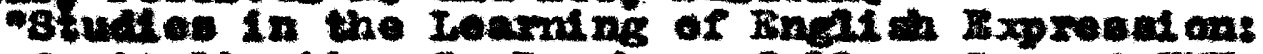

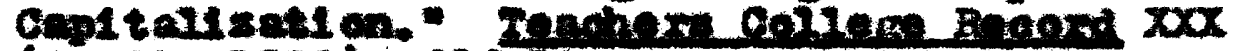

$($ A.12, 2989). 696me.

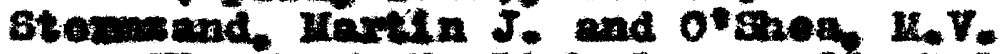

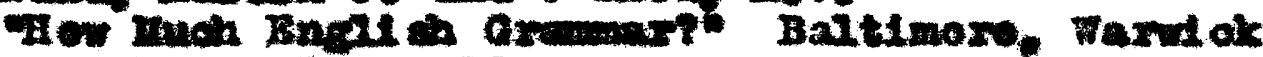
and Totit. Ino. 2924. 


\section{Cunpers II}

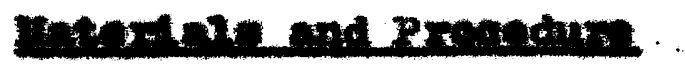

\section{me Ienarine rnatinus}

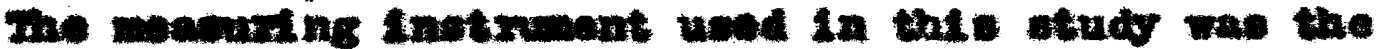

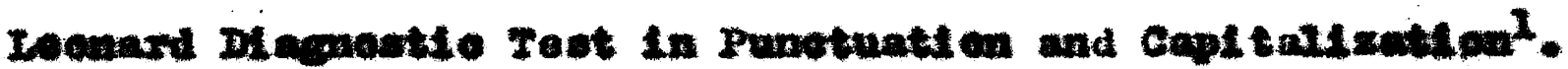
Fafe tert was chesen as the moet ocuprinenatve abd ding

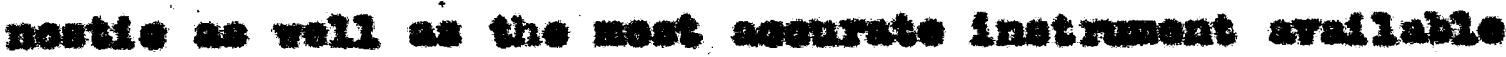

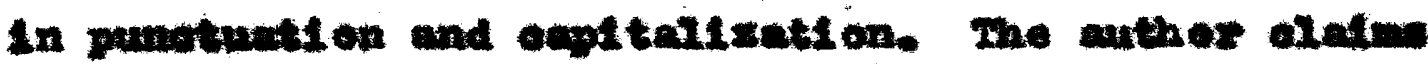

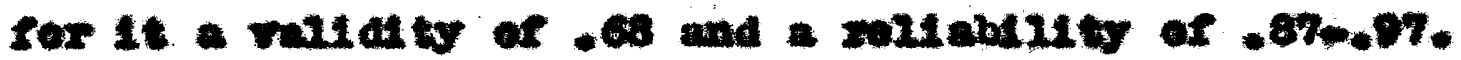

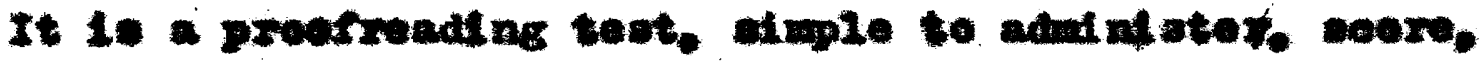
and intexprot. Twaty sules of punotuation and ax

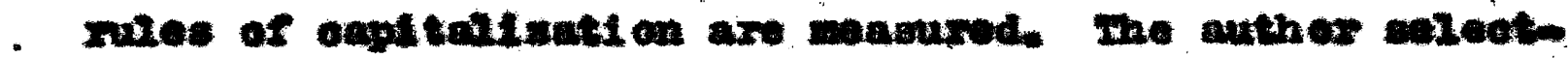

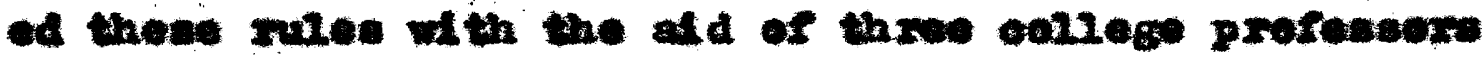

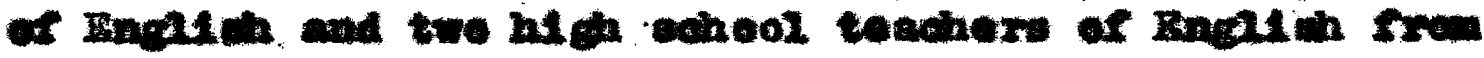

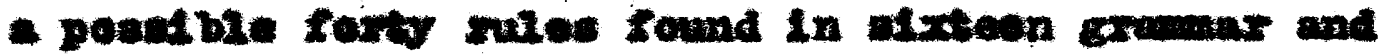
punotuatf on sectes and several hemdbocks of Bnght in form.

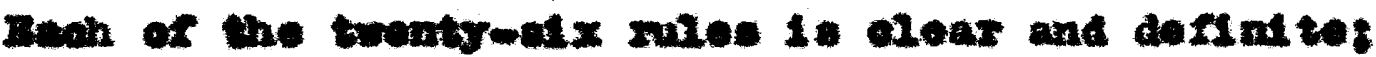
thom to no prortapptine.

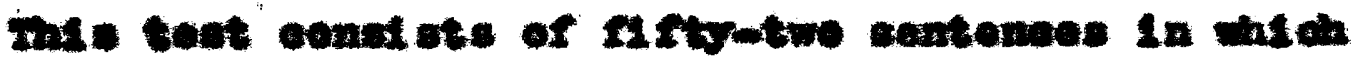
thore axe rour pportumite to nee each of the trontro

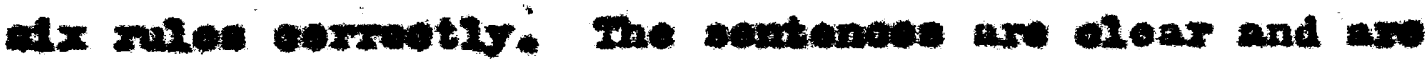

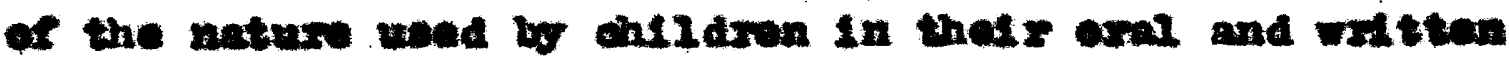
expruast an. Oppextunt the for the eerwoet unage af

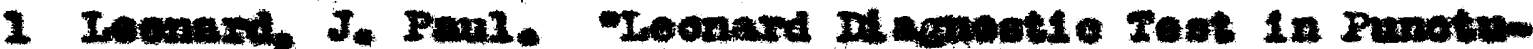

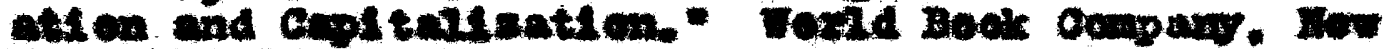
Tort. 1930 . 


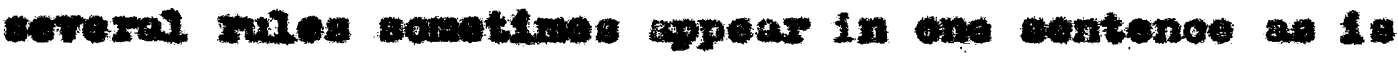
the ease in crovrday unns. The rallaty of this tent reats partialy on the acoumpti on that four opportund tio

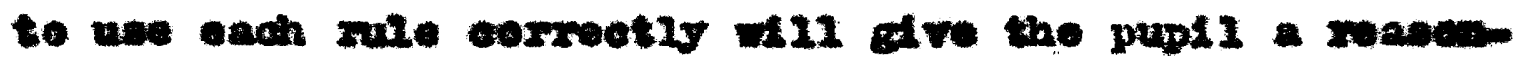
abte chano to demanntrate his ablitg in that ugage.

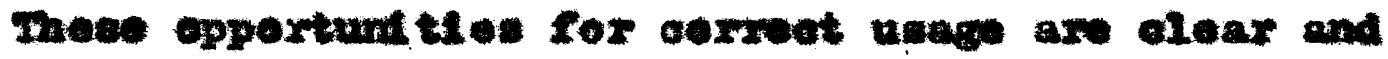

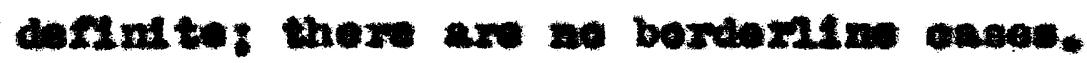

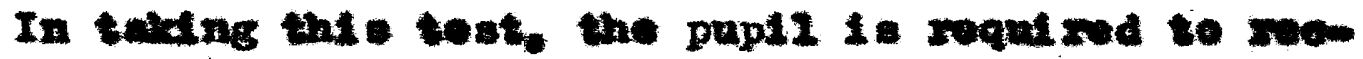

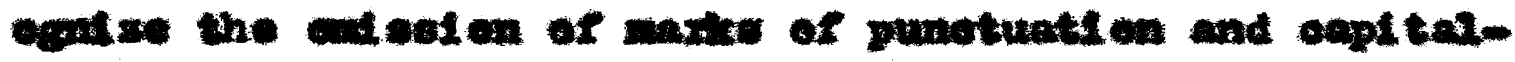

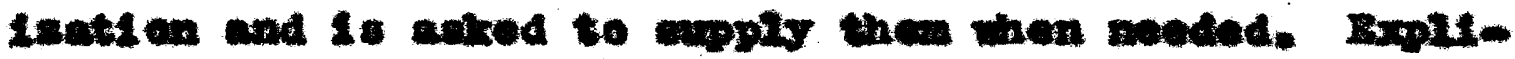

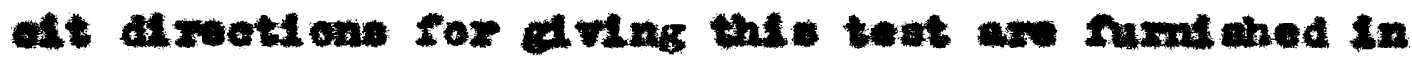

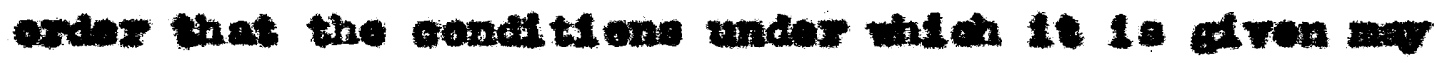
be as underm as posetble. The teot 18 spored by mons of an objeottre ker. Bach exrux counte one point in the total coors. The soors is bow al a poreantage of

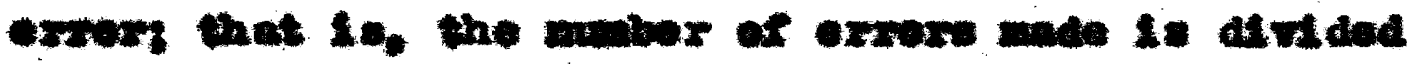

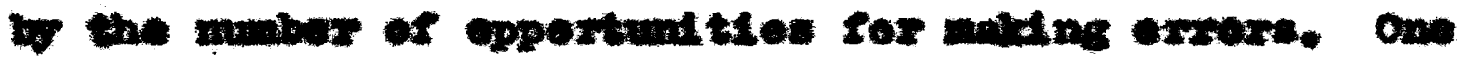

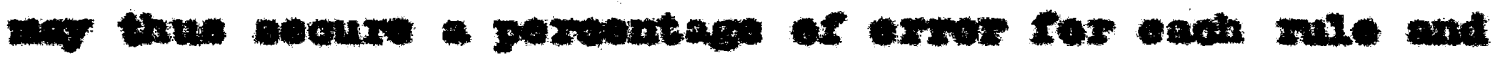

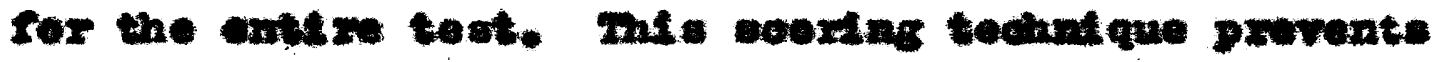
the undne wethting of save rales at the expones of athere.

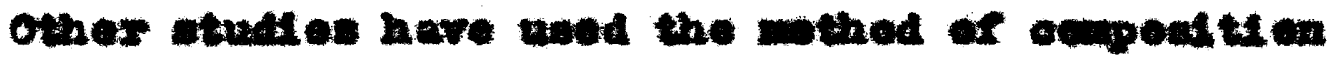

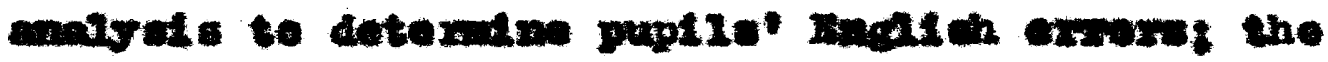

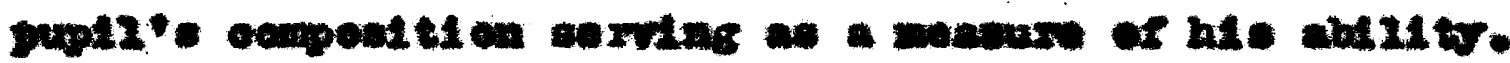

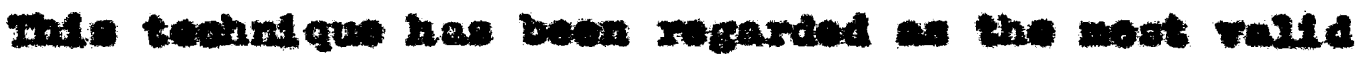

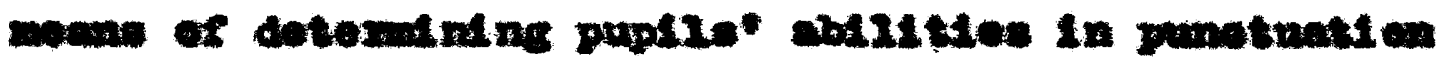


and onptealixati on. Cempost ti on anclyal a, howerer, has several sert minend ompe. Iret, 14 is a 2 aboxt ous proceve. Seowd. a great wase of witten woxk purt be anelyzed in order to becure a renenabie reprenantati on of enoh male. Int rt, wan puptI does not have equal oppertint in each mile usage. miline found that cemprohonatre proefroading teats were remenasiy goud Inatruments (average vall dity, 68 ) for prodloting the are rage muber of formal errexe hl papt2s weuld make

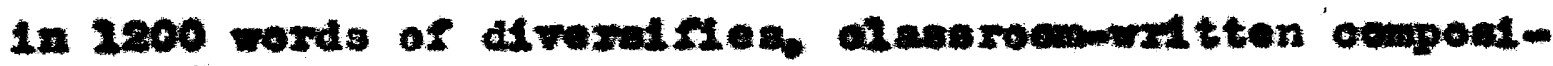
t1 on on fandilar aubjeot matter. me teot used in this etudy has the eame validty $(.68)$ and at the eno

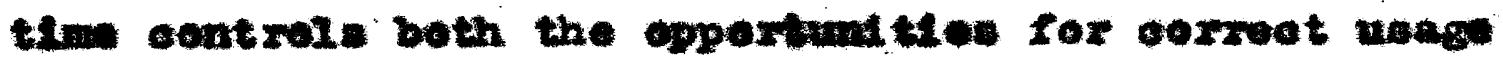
and provtdes an equal repreaentation of euch rule of uoage for each cindid.

In view of this ovidenos, the auther of this atudy

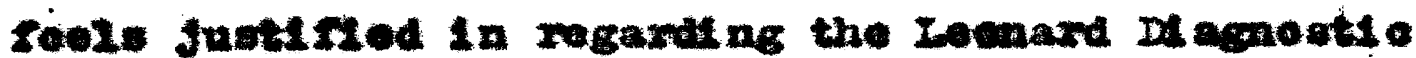
Test in Pungtuati on and Copt taluati on as a quite rokiable mogeurine inatrumont.

\section{monterentad}

The Ioonard test, a oopy of atch in in the eppends.

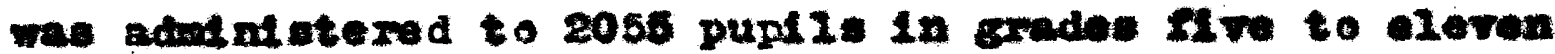

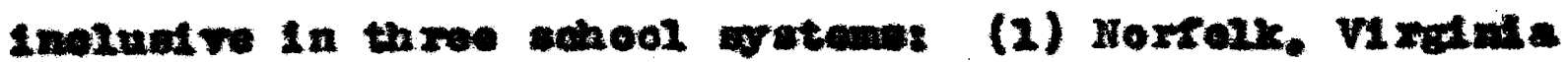

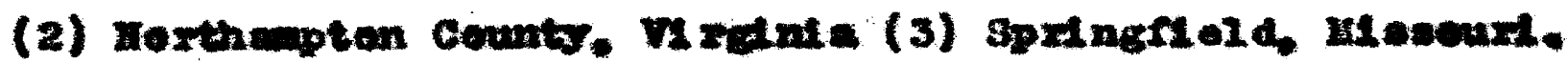
These pupile ware unosected ithith the grades and are

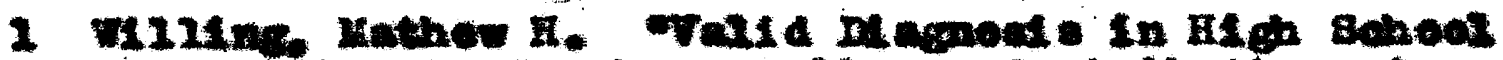

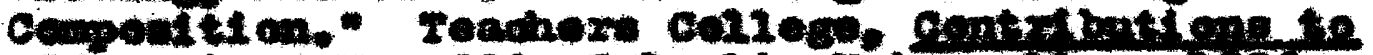

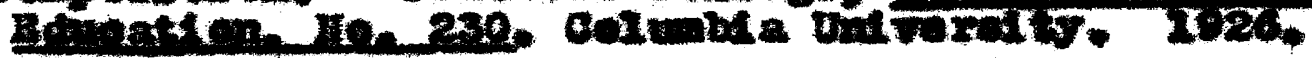


regarded as representative of puptis in these gradeo.

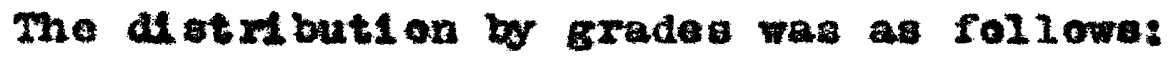

100 puplis in the fifth grade

307 pup 118 in the atxth grade

487 pupiIs in the seventh grade

300 pupila in the elghth errade

312 pup118 in the ninth grade

266 pup 118 in the tenth grade

274 pupile in the eleventh exrade

The dist2l buti on by aretems was:

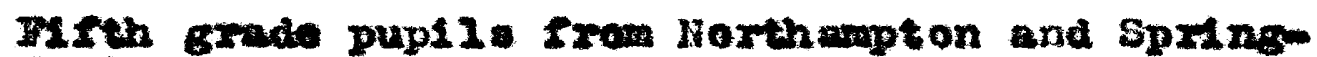
fleza

G1xth Grade pup120 Irow Noxthampton and Springrield

Saventh grade pupils from Norfollk and Northampton

Winth grade pup1 18 from Jorthampton and Ipringeield

Inth Grade puplis from Horthaupton and Springo ILe1d

Tenth grade puy12a from Northapt on and Spring riela

Hieventh grade pujils Irom Hexthampt on and springrield.

The nexthempton aystem is omposed of comparitively anall ruxal Bchooln. Horfolr. in the south, and Spring Ne1d, In the Eld-Weat, aro both ofty sohool wysteme and are ocroposed of laxger scheols. 


\section{Progedure}

The 2055 teste wero adminf etered between Nevamber 14 and Deoumber 11, 1930 by the regular olasarecon teachers under the supervis on of the prinaipala in Werfolk, the county superintendent in Northarpt on, and the di reotor of resesroh in $3 p r i n g f t e l d$. The di reotione printed in the teat mamul were followed in each oyaten,

The testis were soered by the teachere wh the objeative key. Sem of the teschera transferred the reaults of theis tests to the diagnostio charta rurnt shed with the teato. The author transferrod the remainder of the test reanta to the diegneatio charta. The inform at1 on contained on these oharte was then munesartzed on a convantent tabuiation sheet. Copies of the objective key and the tabulation shoet may be found In the appendix. The diagnostia chart provides for the tabulati on of each posalble errer in the order of 1 ts oocurrence In the test. aentence by sentenoe. The tabulation weet prorides for the rearrangoment of the regults by rule muber. The rertical totala indiate the pup118* Boores on all rules togother. These totals were then divded to Indeate total errors in oapltallzation and tetal exrors in punotuation. The horizontal totale in dieate the total errom made by all pupils in euch rule. The aovuracy of this study restis partialiy on the rellabluty of the test results in each grade. The following method was used to determine the number or 
pup118" soores necessary to ingure a hloh degree of reilabilfty. Rankinga on the peroentages made in each rule rere taken at intervale of fifty pup1lo' soores. The thi rd ranking (150 pupili) was found to bo as oonstant as subsequent rankings. Inis seems to ind a ate that the rellablitt of groups of one hundred and fifty of these unseleoted pup110' teats is as high as largex mubers. Hore than two hundred and fifty teots wero used in each of the grades, exoept grade five in wich one hundred puplis were toted. There 18 . therefore. a resoonable basis for the asaumpti on that the roalts in grades al $x$, geten, ight, nine, ten, and oleven are hionly rellable. The reaulta in grade fire may be oonst de red lese rell able. 
Chapter III

\section{the Ragurts}

The findings of this otudy aro arranged in the order of the problems aet up in anapter I:

(1) To determine the relative growth in ability to punotuste and eapltallze oorrectly from grade to grade.

(2) To dotermine the rolative perel ateney of errexs in punotuation and oapitalizati on made by pup11. In aach grade from the fifth to the eleventh inolusive.

(3) To determi ne whether or not the ranking order of errore made by pupiso in rules of punotueti an and capitallzation romad in constant from grades fire to eleven inoluelve.

The muivers of the rules in the Leonard test did not foll ow the order of peroentages of error made on these rules by the pupilo in any grade in this study. The author. therefore, arranced the rules in grade five in the order of deconding peroontages of error in punotuntion and in aapitalization to proride a definite basis for oomparing the growth ahow in the wuooeding grades. This rerlsed nule numbering was then fellowed throughout the ent1 re study.

The rules of punatuati on and oapt tallzati on usod In this study aro presented here in the oxder followed 
Cantaluattm

Fure nuber 1 - Captealse the $\mathrm{A}$ rot word in each quotation.

Rule muber 2 - Captealse the prinofpral worde in titien.

Rule muber 3 - Capitalise ench proper adjeotive.

rule muber 4 - Copt talse each proper nown.

Ante number 5 - Captallse the pronoun I.

Fune muber 6 - Cuptearise the If ret word in ench netenoe.

\section{Bungtuation}

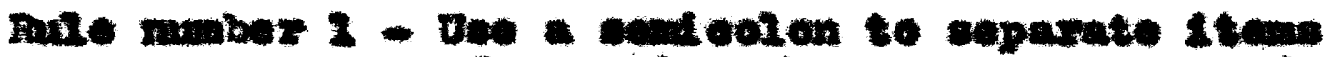
of a sortes then eomate ax uned Etatr term.

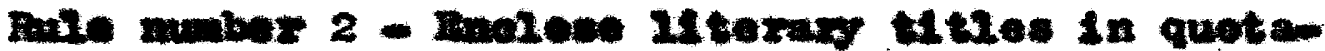
then varers.

Rule zumber 3 - Pleoe a peried after eech abbuntation of int tial.

Pure wainer 4 - Voe the apeotrophe to how the ponsesetre of a noun.

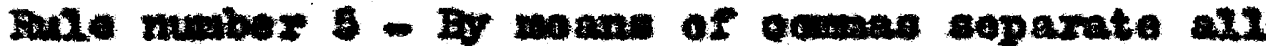
of reget guotati on frem the reat of the tex matter.

Pale nutber 6 - Place a colon batore formal llat.

Fure maber 7 - Ue an apostroghe to lnal a ate the culeat on of a Iatter in a contrao. tion.

Rule mumer 8 - Separate a paremthetioal exprenet on frem the west of the text ateter iv canas or daches.

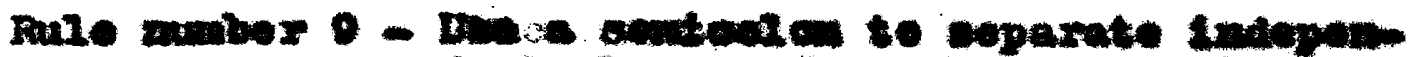

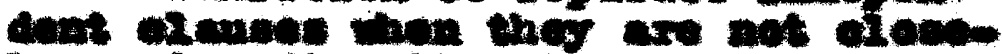

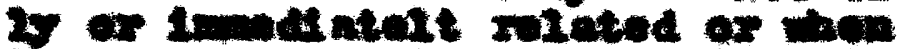
Ares aw not jedned beajunteno. 


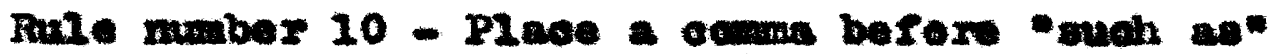
wen ueed in a centenoe to interm rupt the prinotpal thought or taes ueed appoat tively ex parenthetical1y.

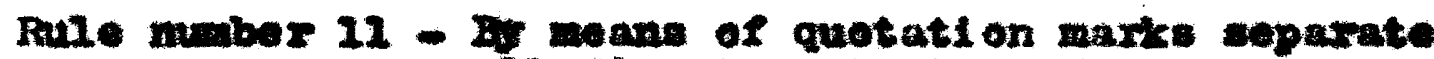
21 d reot quotatl one Irom the wast of the text natter.

Rule muber 22 - Compe are umanz used to peparate Indepondent oleueves that are jesned bo such opexdingtes as but ifs

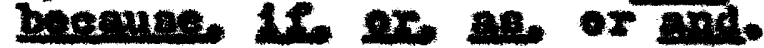

Rule muber 23 - Set of by comas the name of a permon addroeced.

Pude nomber 14 - When a mbordinate almupe precedes a matn olanes. Iollow the anboxunite alane 4 a fomme.

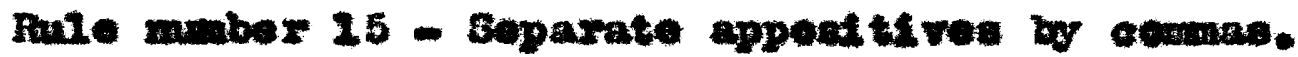

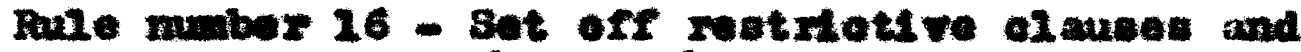
phranes by ecumas.

Pule muber 27 - Mace a quetion marle at the and of an interwegative sentenoe.

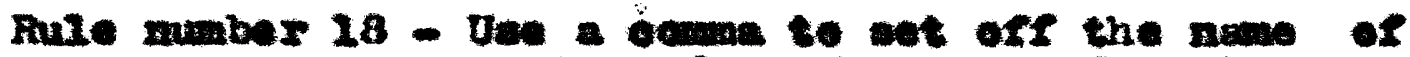
- otete Irow the newe of a prea wthin the atese. a stroos Juan a aty. the gear from the dos of the month, a plaoe from a date ox a nam from place.

Fule munex 19 - Une the cewne to peparate worch and phrases, and anerese in sexlos. and put a ocwan berexe and wion 1t it newd to jata the last two 1tews of the nexteo.

Fune mubar 20 - 2200e a perted at the and of a

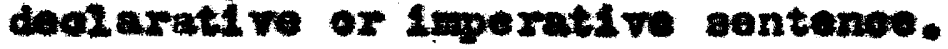

\section{groth in Abrits}

Teble A thowe the nule mumbrs. the nuber of eppox

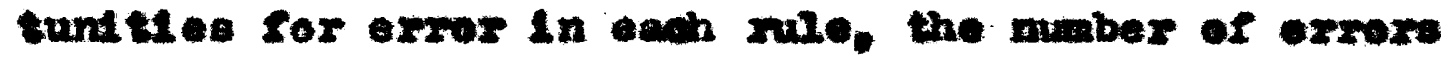

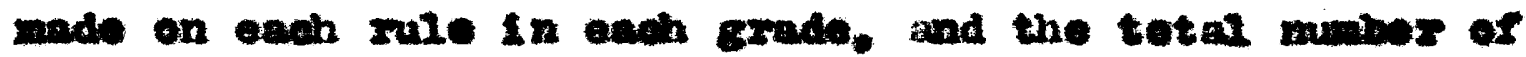




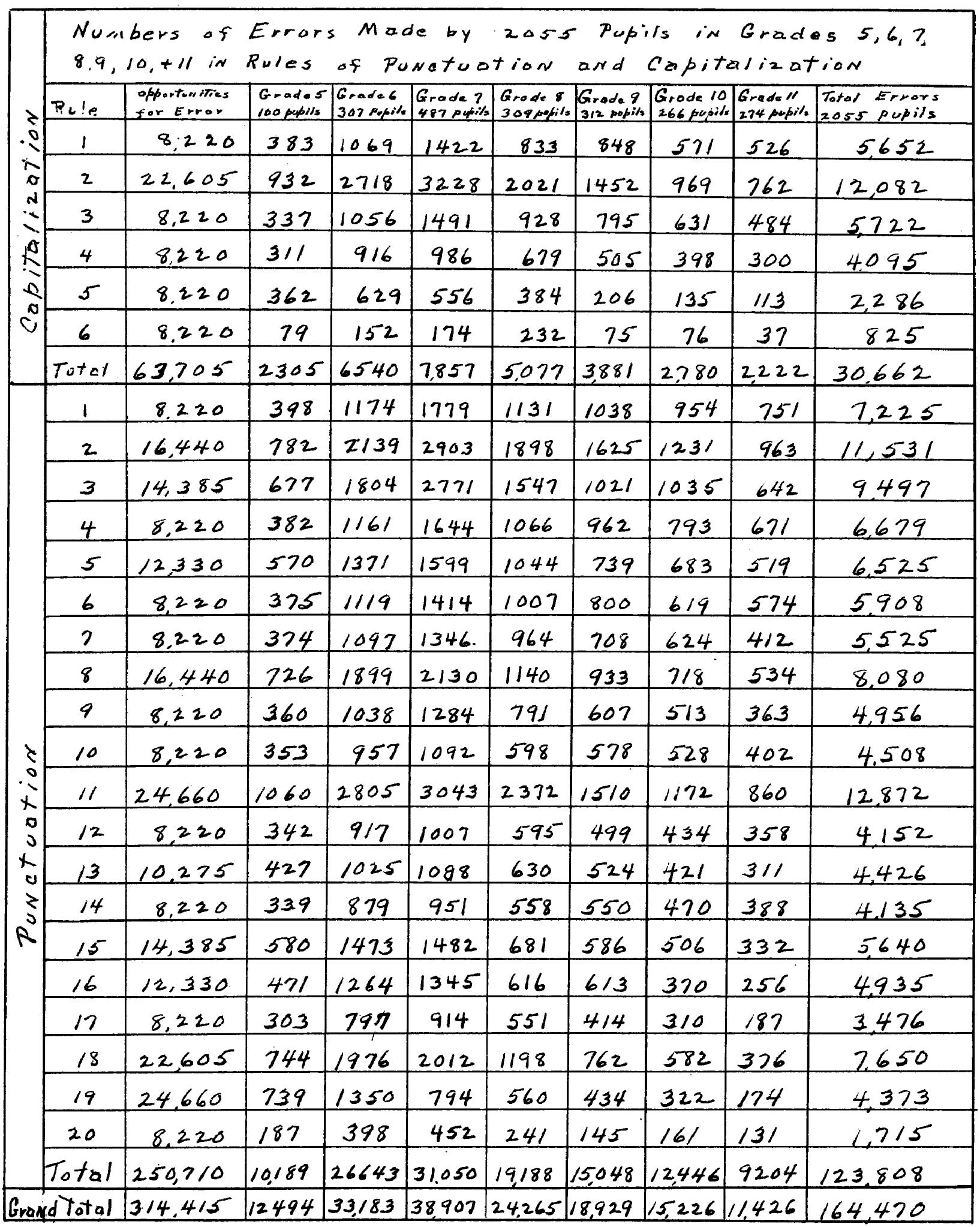


Table B

Percentages of Errors Made by 2005 Pupils in Grades $5,6,7,8,9,10,+11$ in Rules of Ponctuation and Capitalization

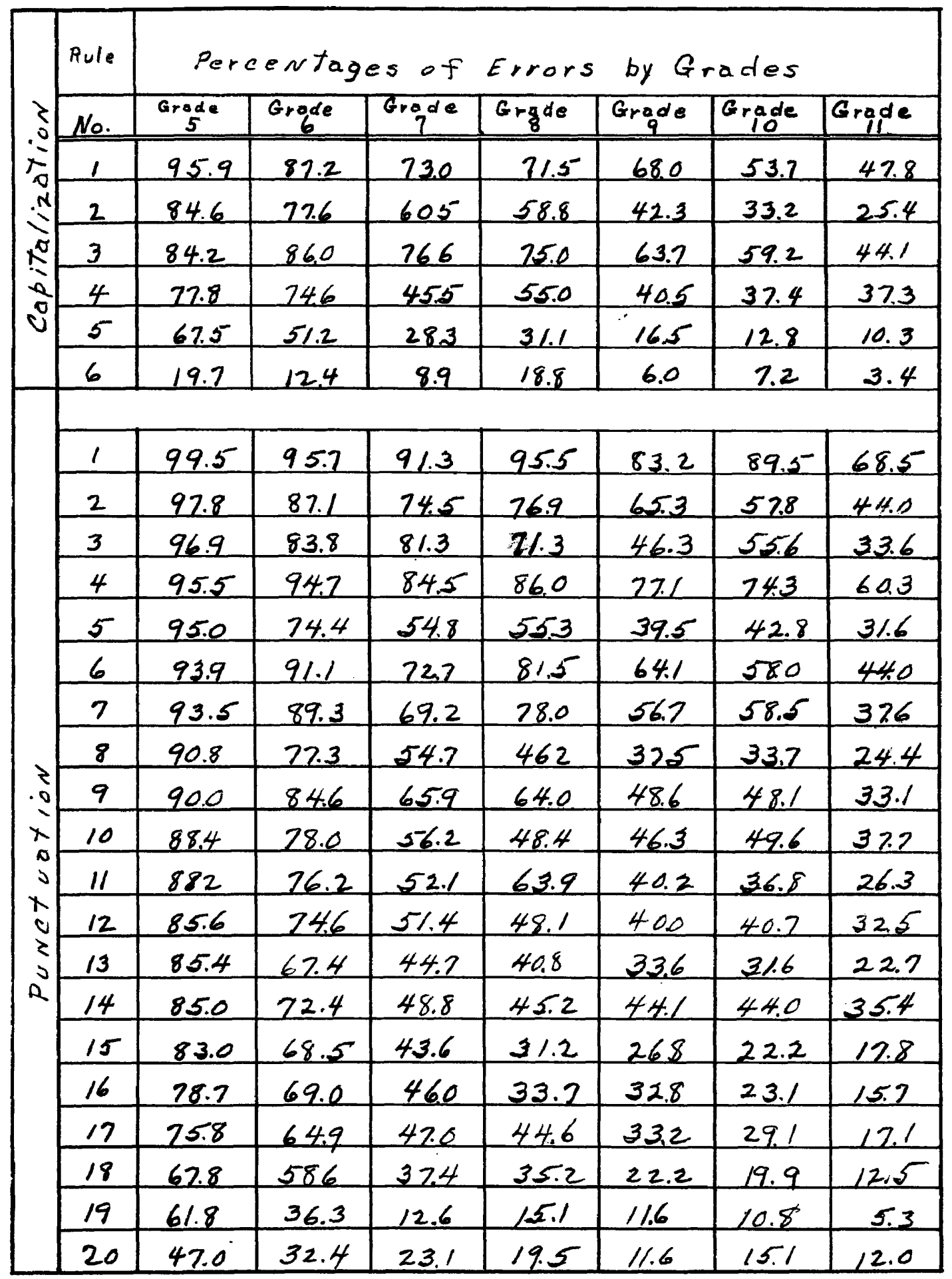


- rrern made in each rule. 2055 pupile ath 324.425 opportunttice for exroxe made a grand total or 164,472 errors. Thil study. therafore, is baeed on this group of exroxw. Table $\mathrm{B}$ cheme the peroentiges of errer made on each rale in each grade. Tables maber 1, 2, 3, 4,

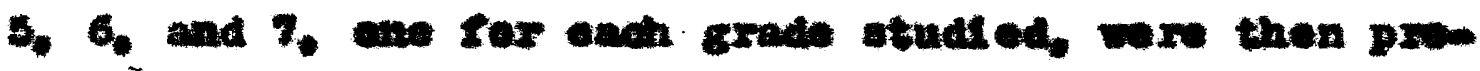
paxed to propont the sooulte in each cxade separatery. Gxaghe were then propared to present the rovulte in

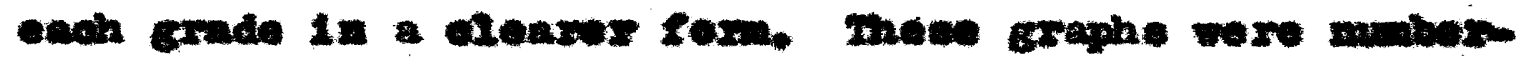
od to cerreopend ath the number of the tables for the

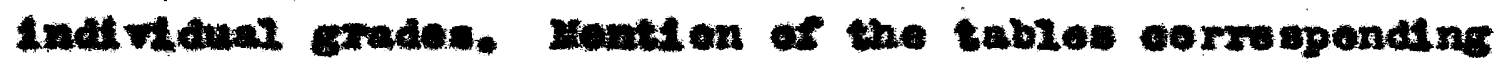
to each groph 421 be anteed in the reot of this enapter.

Bach of these tables and graphe vas Avided inte twe eoctions: the firt presenting the reaults in capt tallzati on and the reoond in punotumti on.

\section{Grade Ine.}

Graph muber 1 shows the achtevement of 100 If fth

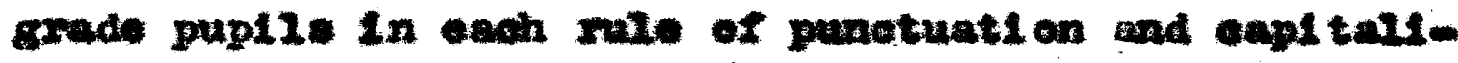

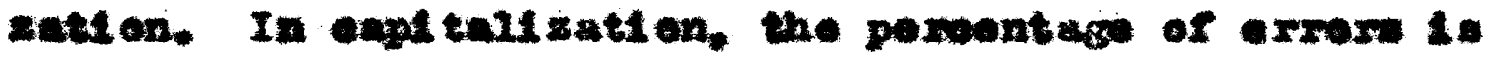

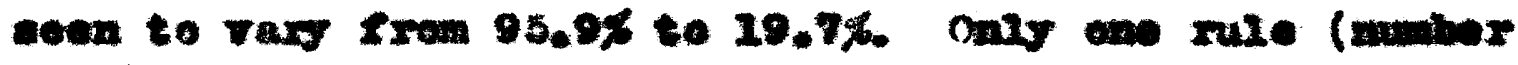

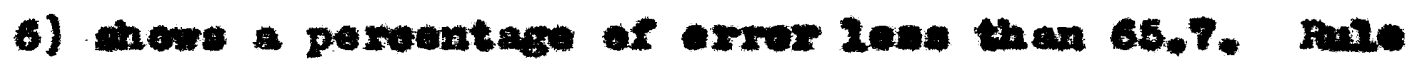

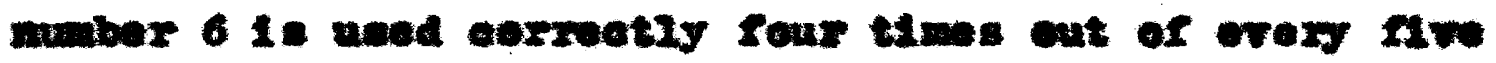
epportunteles. The romaling five rizen are used correotis leas than four thms in erex sen opporturteles. In pranotuation ouly one of the twenty rules is 
Table 1

Percentages of Error Made by 100 Fifth Grade Pupils onsix poles of Capitalization and Turenty Rules of Purctuation

Capitalization

\begin{tabular}{|c|c|c|c|}
\hline $\begin{array}{l}\text { Rule } \\
\text { Number }\end{array}$ & \begin{tabular}{|} 
Nomper of \\
epportundies
\end{tabular} & $\begin{array}{c}\text { Nomber of } \\
\text { Erroxs }\end{array}$ & $\begin{array}{l}\text { Percent of } \\
\text { Exrer }\end{array}$ \\
\hline 1 & 400 & 383 & 959 \\
\hline 2 & 1100 & 932 & 84.6 \\
\hline 3 & 400 & 337 & 842 \\
\hline 4 & 400 & $3 / 1$ & 328 \\
\hline 5 & 400 & 263 & 65.7 \\
\hline 6 & 400 & 79 & 19.7 \\
\hline \multicolumn{4}{|c|}{ FunCTUATION } \\
\hline 1 & 400 & 398 & 995 \\
\hline 2 & 800 & 782 & 928 \\
\hline 3 & 700 & 622 & 96.9 \\
\hline 4 & 400 & 382 & 95.5 \\
\hline 5 & 600 & 570 & 95.0 \\
\hline 6 & 400 & 325 & 93.9 \\
\hline 2 & 400 & 374 & 93.5 \\
\hline 8 & 800 & 726 & 90.8 \\
\hline 9 & 400 & 360 & 900 \\
\hline 10 & 400 & 353 & 88.4 \\
\hline 11 & .1200 & 1060 & 88.2 \\
\hline 12 & 400 & 342 & 856 \\
\hline 13 & 500 & 427 & 85.4 \\
\hline 14 & 400 & 339 & 85.0 \\
\hline 15 & 200 & 580 & 83.0 \\
\hline 16 & 600 & 421 & 28.7 \\
\hline 12 & 400 & 303 & 75.8 \\
\hline 18 & 1100 & 744 & 67.8 \\
\hline 19 & 1200 & $73 q$ & 618 \\
\hline 20 & 400 & 187 & 47.0 \\
\hline
\end{tabular}



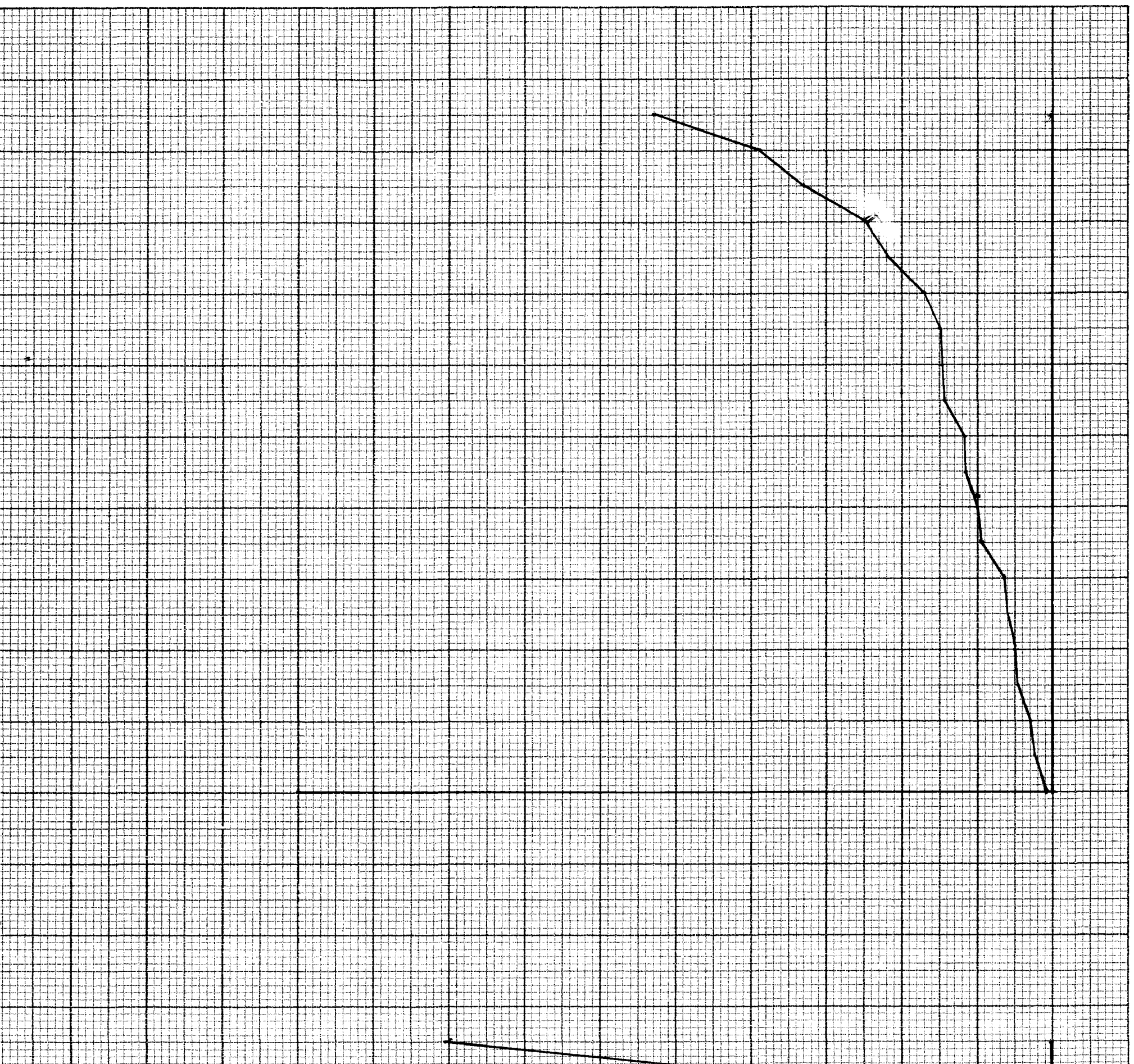
Table 2

Percentage of Error Made bx 300 Sixth Grade Pupils on six Rules of Cabitolization anei Twenty Rules of Punctuation

\begin{tabular}{|c|c|c|c|}
\hline \multicolumn{4}{|c|}{$\begin{array}{l}\text { Grade } 6 \text { Capitalization } \\
\text { Rule } \\
\text { Ropportunties Number of }\end{array}$} \\
\hline 1 & 1228 & 1069 & 87.2 \\
\hline 2 & 3377 & 2718 & 7.6 \\
\hline 3 & $12 \sum 8$ & 1056 & 86.0 \\
\hline 4 & 1228 & 916 & 24.6 \\
\hline 5 & 1228 & 629 & 51.2 \\
\hline 6 & 1228 & 152 & 12.4 \\
\hline \multicolumn{4}{|c|}{ Punctuation } \\
\hline 1 & 1228 & 1174 & 95.7 \\
\hline 2 & 2456 & 2139 & 87.1 \\
\hline 3 & 2149 & 1804 & 83.8 \\
\hline 4 & 1228 & 1161 & 94.7 \\
\hline 5 & 1842 & 1321 & 74.4 \\
\hline 6 & 1228 & 1119 & 91.1 \\
\hline 3 & 1228 & 1092 & 89.3 \\
\hline 8 & 2456 & 1899 & 22.3 \\
\hline 9 & 1228 & 1038 & 84.6 \\
\hline 10 & 1228 & 957 & 28.0 \\
\hline 11 & 3684 & 2805 & 76.2 \\
\hline 12 & 1228 & 917 & 74.6 \\
\hline 13 & 1535 & 1025 & 62.4 \\
\hline 14 & 1228 & 879 & 224 \\
\hline 15 & 2149 & 1473 & 68.5 \\
\hline 16 & 1842 & 1264 & 69.0 \\
\hline 12 & 1228 & 797 & 64.9 \\
\hline 18 & 3377 & 1976 & 58.6 \\
\hline 19 & 3684 & 1360 & 36.8 \\
\hline 20 & 1228 & 398 & 32.4 \\
\hline
\end{tabular}




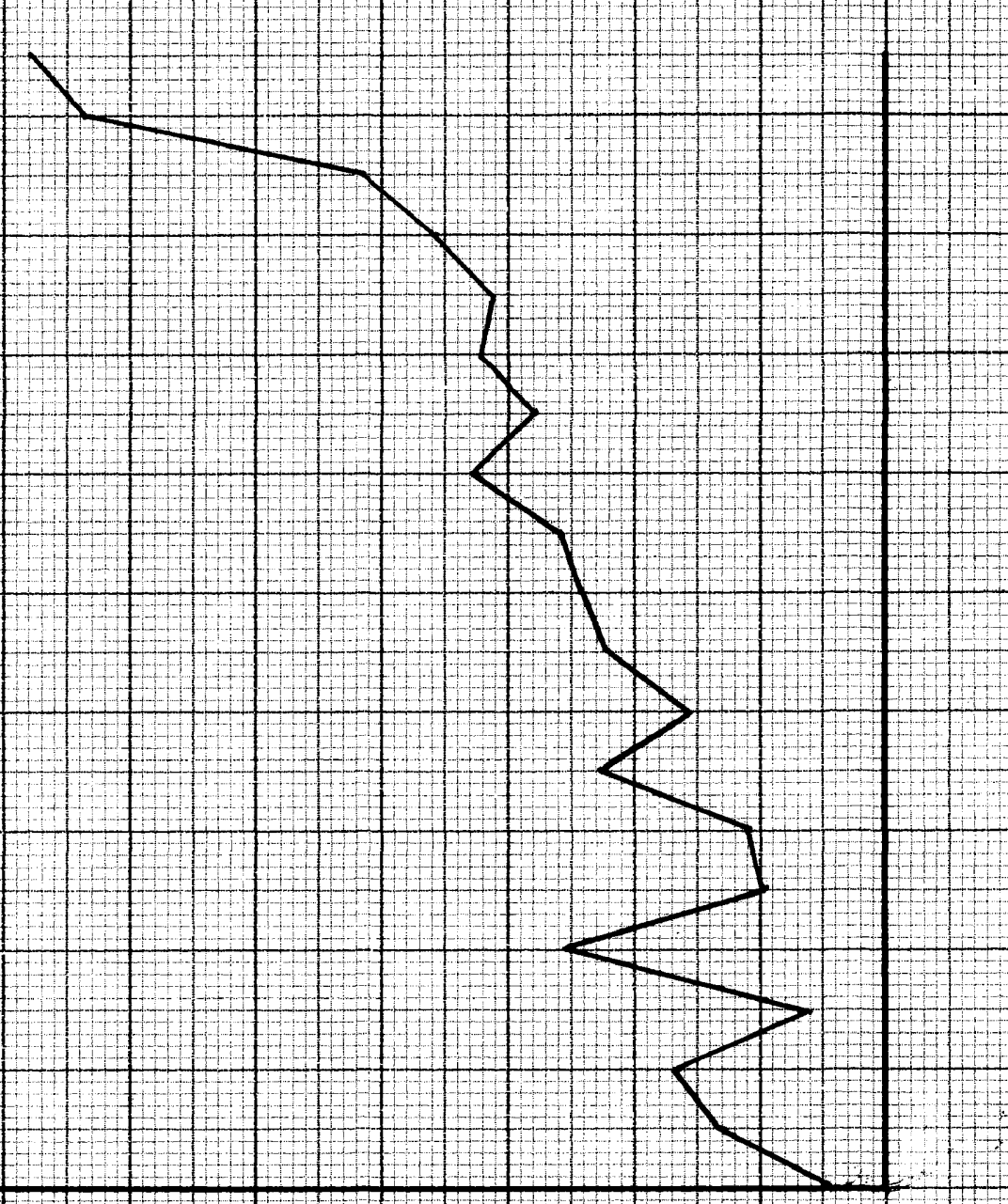


Table 3

Percentages of Error Made by 487 severith Grade Pupils on six Rules of Capitalization and Twenty Rules of Punctuation

\begin{tabular}{|c|c|c|c|}
\hline \multicolumn{4}{|c|}{ Capitolizalion } \\
\hline $\begin{array}{l}\text { Rule } \\
\text { Nusber }\end{array}$ & $\begin{array}{l}\text { Opportunnieg } \\
\text { por Exkox }\end{array}$ & $\begin{array}{l}\text { Nomber } \\
\text { of Errars }\end{array}$ & $\begin{array}{l}\text { Perecent } \\
\text { of Exror }\end{array}$ \\
\hline 1 & 1948 & 1422 & 23.0 \\
\hline 2 & 5357 & 3228 & 60.5 \\
\hline 3 & 1948 & 1491 & 26,6 \\
\hline 4 & 1948 & 986 & 45.5 \\
\hline 5 & 1948 & 556 & 28.3 \\
\hline 6 & 1948 & 124 & 8.9 \\
\hline \multicolumn{4}{|c|}{ PUNCTUATION } \\
\hline 1 & 1948 & 1779 & 91,3 \\
\hline$\varepsilon$ & 3896 & 2903 & 745 \\
\hline 3 & 3409 & 2721 & $8 / 3$ \\
\hline 4 & 1948 & 1644 & 84.5 \\
\hline 5 & 2922 & 1599 & 54.8 \\
\hline 6 & 1948 & 1414 & 22.7 \\
\hline 2 & 1948 & 1346 & 69.2 \\
\hline 8 & 3896 & 2130 & 54.2 \\
\hline 9 & 1948 & 1284 & 65.9 \\
\hline 10 & 1948 & 1092 & 56.2 \\
\hline 11 & 5844 & 3043 & 52.1 \\
\hline 12 & 1948 & 1007 & 51.4 \\
\hline 13 & 2435 & 1088 & 44.7 \\
\hline 14 & 1948 & 951 & 48.8 \\
\hline 15 & 3409 & 1482 & 43.6 \\
\hline 16 & 2922 & 1345 & 46.0 \\
\hline 12 & 1948 & 914 & 47.0 \\
\hline 18 & 5357 & 2012 & 37.4 \\
\hline 19 & 5844 & 794 & 13.6 \\
\hline 20 & 1948 & 452 & 2.3 .1 \\
\hline
\end{tabular}



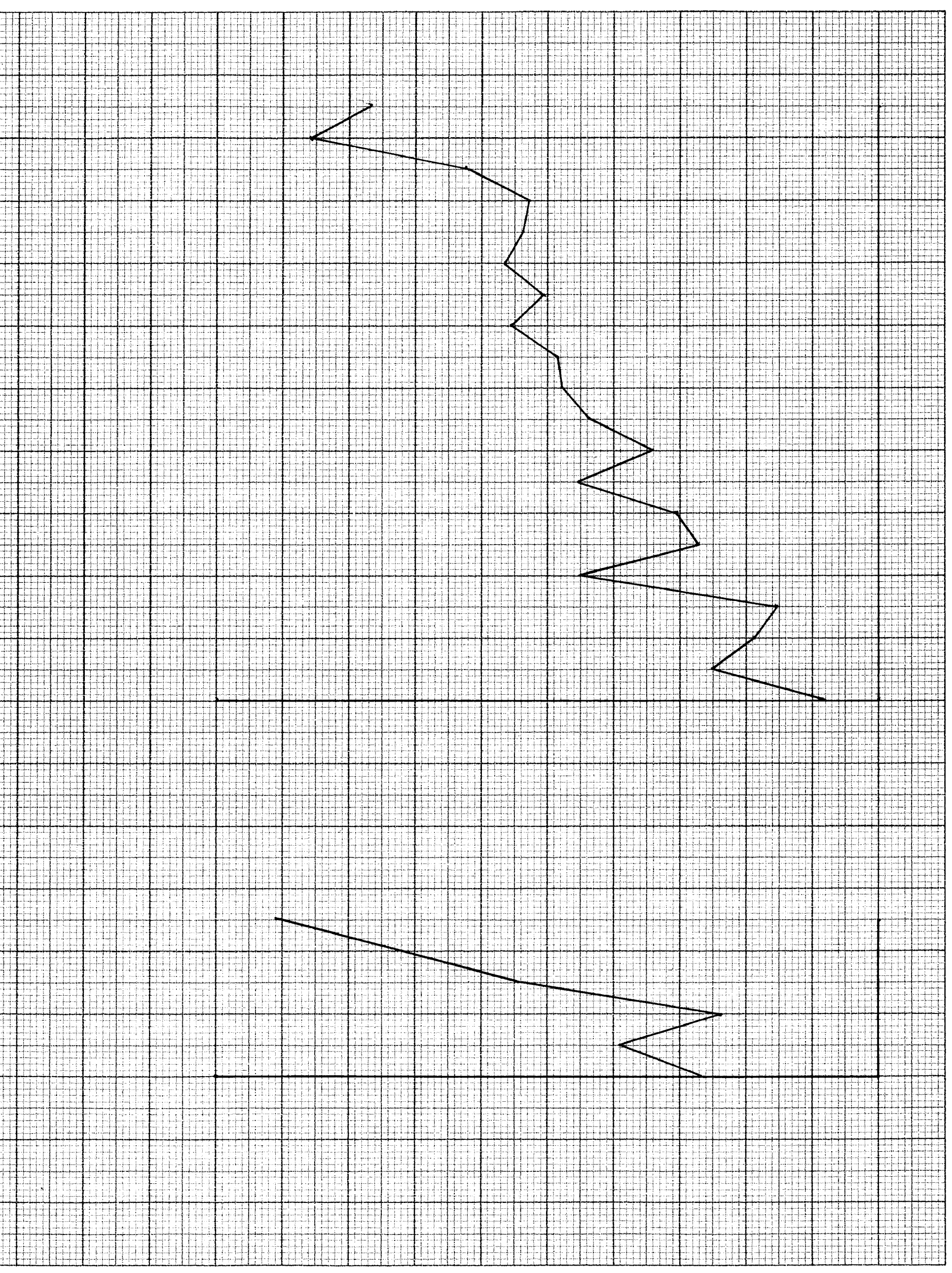
Table 4

Percertaqes of Error Made by 309 Eighth Grade Pupils on Six Rules of Capitalization ond Twenty Rules of Punctuotion

\begin{tabular}{|c|c|c|c|}
\hline \multicolumn{4}{|c|}{ CapiTalizotion } \\
\hline Nule & $\begin{array}{l}\text { opporFunities } \\
\text { cer Errer }\end{array}$ & $\begin{array}{l}\text { Nowber of } \\
\text { Evrors }\end{array}$ & $\begin{array}{l}\text { Pereent } \\
\text { Error }\end{array}$ \\
\hline 1 & 1236 & 833 & 715 \\
\hline 2 & 3399 & 2021 & 58.8 \\
\hline 3 & 1236 & 928 & 75.0 \\
\hline 4 & 1236 & 679 & 55.0 \\
\hline 5 & 1236 & 384 & $3 / .1$ \\
\hline 6 & 1236 & 232 & 18.8 \\
\hline \multicolumn{4}{|c|}{ Punctuation } \\
\hline 1 & 1236 & 1131 & 95.5 \\
\hline 2 & 2472 & 1898 & 76.9 \\
\hline 3 & 2163 & 1.547 & 21.3 \\
\hline 4 & 1236 & 1066 & 86.0 \\
\hline 5 & 1854 & 1044 & 55.3 \\
\hline 6 & 1236 & 1007 & 81.5 \\
\hline 7 & 1236 & 964 & 78.0 \\
\hline 8 & 2472 & 1140 & 46,2 \\
\hline 9 & 1236 & 291 & 640 \\
\hline 10 & 1236 & 598 & 48.4 \\
\hline 11 & 3708 & 2372 & 63.9 \\
\hline 12 & 1236 & 595 & 48.1 \\
\hline 13 & 1545 & 630 & 408 \\
\hline 14 & 1236 & 558 & 45.2 \\
\hline 15 & 2163 & 681 & $3 / 2$ \\
\hline 16 & 1854 & $6 / 6$ & $33 . /$ \\
\hline 17 & 1236 & 551 & 44.6 \\
\hline 18 & 3399 & 1198 & 35.2 \\
\hline 19 & 3708 & 560 & 15.1 \\
\hline 20 & 1236 & 241 & 195 \\
\hline
\end{tabular}




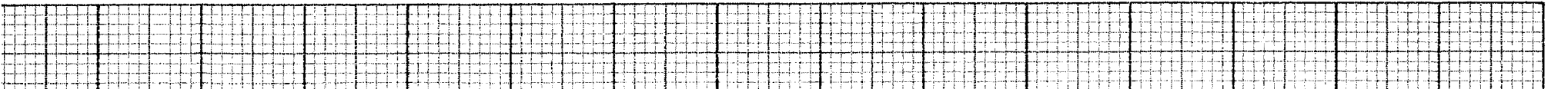
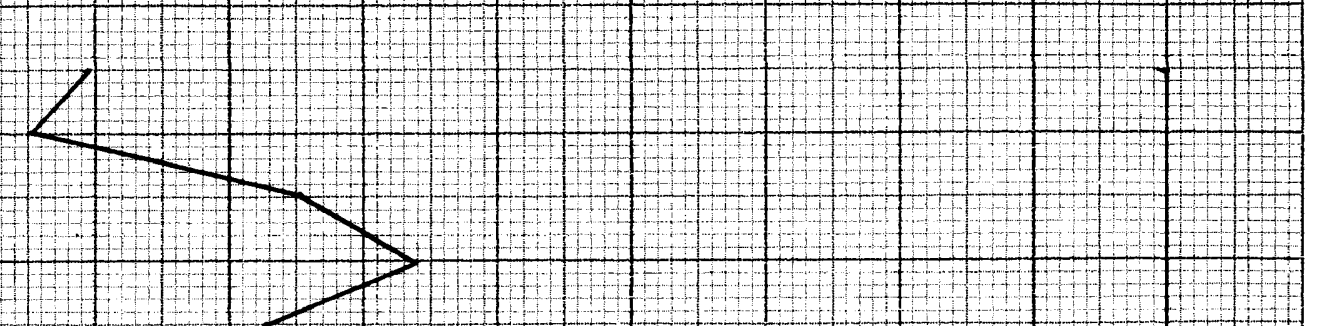

$+1$
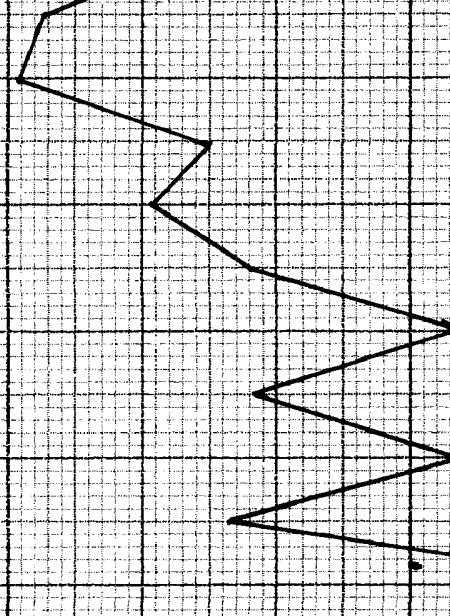
Table 5

Pereentages of Error Nade by $3 / 2$ Ninth Grade Pupils on six Rules of CapiTalization and Tusenty Rules of Punctuotion

\begin{tabular}{|c|c|c|c|}
\hline \multicolumn{4}{|c|}{ Grade 9 Copitalization } \\
\hline $\begin{array}{l}\text { Tole } \\
\text { Number }\end{array}$ & $\begin{array}{l}\text { OpporTunties } \\
\text { for Error }\end{array}$ & $\begin{array}{l}\text { Namber of } \\
\text { Eerexs }\end{array}$ & $\begin{array}{l}\text { Perent } \\
\text { of Error }\end{array}$ \\
\hline 1 & 1248 & 848 & 680 \\
\hline 2 & 3432 & 1452 & 42.3 \\
\hline 3 & 1248 & 795 & 63.7 \\
\hline 4 & 1248 & 505 & 40.5 \\
\hline 5 & 1248 & 206 & 16.5 \\
\hline 6 & 1248 & 75 & 6.0 \\
\hline \multicolumn{4}{|c|}{ Punctuotion } \\
\hline 1 & 1248 & 1038 & 83.2 \\
\hline 2 & 2496 & 1625 & 65.3 \\
\hline 3 & 2184 & 1021 & 46,3 \\
\hline 4 & 1248 & 962 & 77.1 \\
\hline 5 & 1872 & 739 & 39.5 \\
\hline 6 & 1248 & 800 & 64.1 \\
\hline 2 & 1248 & 708 & 56.7 \\
\hline 8 & 2496 & 933 & 37.5 \\
\hline 9 & 1248 & 607 & 48.6 \\
\hline 10 & 1248 & 578 & 46.3 \\
\hline 11 & 3244 & 1510 & 40.2 \\
\hline$\angle 2$ & 1248 & 499 & 40.0 \\
\hline 13 & 1560 & 524 & 336 \\
\hline 14 & 1248 & 550 & 44.1 \\
\hline 15 & 2184 & 586 & 26.8 \\
\hline 16 & 1872 & $6 / 3$ & 32.8 \\
\hline 17 & 1248 & 414 & 33.2 \\
\hline 18 & 3432 & 762 & 22.2 \\
\hline 19 & 3472 & 434 & 11.6 \\
\hline 20 & 1248 & 145 & 11.6 \\
\hline
\end{tabular}




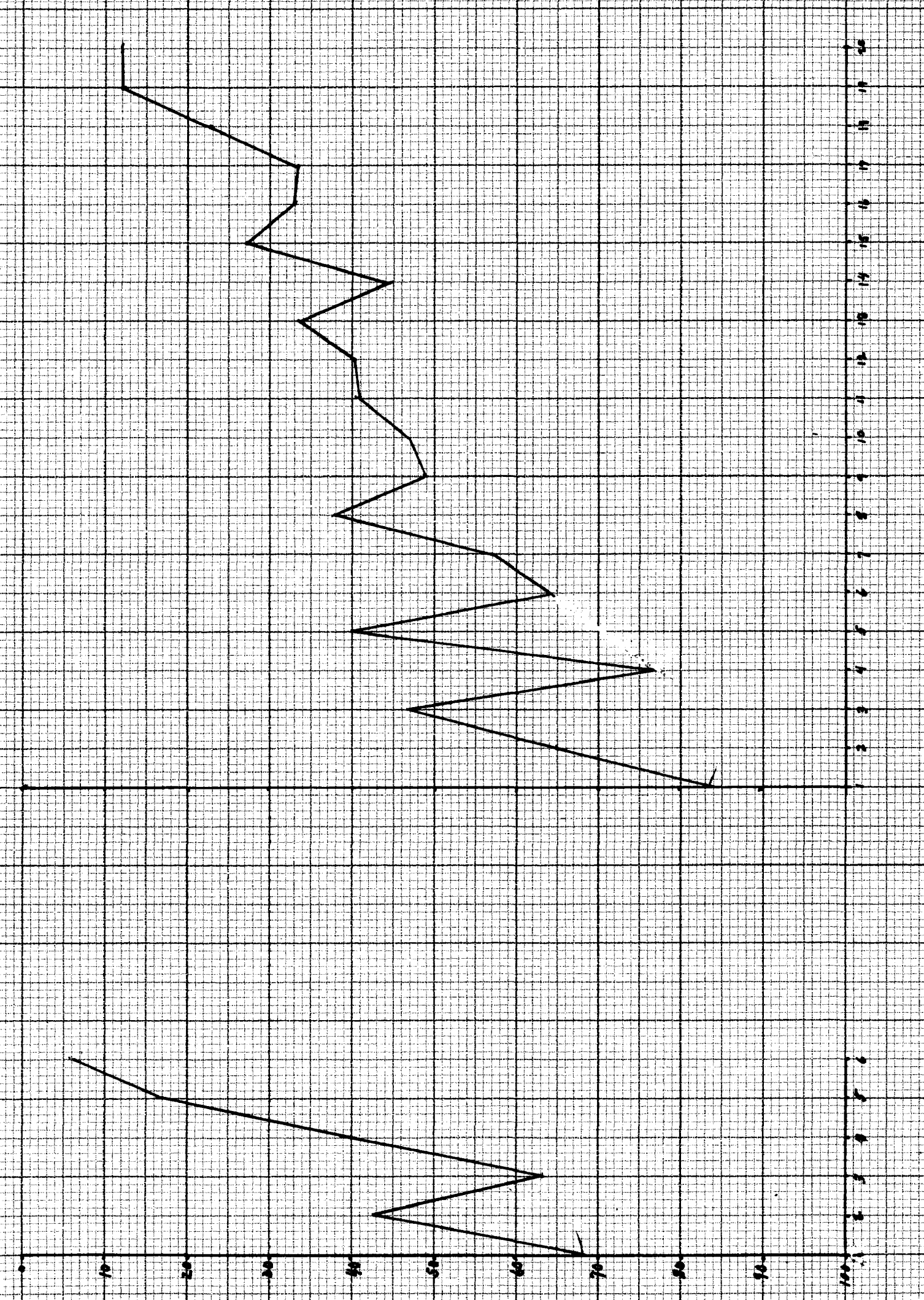




$$
\begin{aligned}
& \text { Table } 6 \\
& \text { Percentages op Error Made by } 266 \text { Terith } \\
& \text { Grade Pupils on Six Pules of Capitolization } \\
& \text { and Twenty Ruies of Punctootion }
\end{aligned}
$$

\begin{tabular}{|c|c|c|c|}
\hline \multicolumn{4}{|c|}{ Gracie capitoliz otion' } \\
\hline $\begin{array}{l}\text { Rule } \\
\text { susber }\end{array}$ & $\begin{array}{l}\text { opporionities } \\
\text { for Exver }\end{array}$ & $\begin{array}{l}\text { Nonber } \\
\text { of Érors }\end{array}$ & $\begin{array}{l}\text { Peraent } \\
\text { of Ervor }\end{array}$ \\
\hline$i$ & 1064 & 521 & 53.7 \\
\hline 2 & 2926 & 969 & 33.2 \\
\hline 3 & 1064 & 631 & 59.2 \\
\hline 4 & 1064 & 398 & 32,4 \\
\hline 5 & 1064 & 135 & 12.8 \\
\hline 6 & 1064 & 76 & 7.2 \\
\hline \multicolumn{4}{|c|}{ PUNCTUaTION } \\
\hline 1 & 1064 & 954 & 89.5 \\
\hline 2 & $2 / 28$ & 1231 & 57.8 \\
\hline 3 & 1862 & 1035 & 55.6 \\
\hline 4 & 1064 & 793 & 24.3 \\
\hline 5 & 1596 & 683 & 42,8 \\
\hline 6 & 1064 & $6 / 9$ & 58.0 \\
\hline 2 & 1064 & 624 & 585 \\
\hline 8 & $2 / 28$ & 218 & 33.7 \\
\hline 9 & 1064 & 513 & 48.1 \\
\hline$\angle 0$ & 1064 & 528 & 49.6 \\
\hline 11 & $3 / 92$ & 1172 & 36.8 \\
\hline 12 & 1064 & 434 & 40.7 \\
\hline 13 & 1330 & 421 & 31.6 \\
\hline 14 & 1064 & 470 & 44.0 \\
\hline 15 & 1862 & 506 & 27.2 \\
\hline 16 & 1596 & 370 & 23.1 \\
\hline 17 & 1064 & 310 & 29.1 \\
\hline 18 & 2926 & 582 & 19.9 \\
\hline 19 & $3 / 92$ & 322 & 10.8 \\
\hline 20 & 1064 & 161 & 15.1 \\
\hline
\end{tabular}




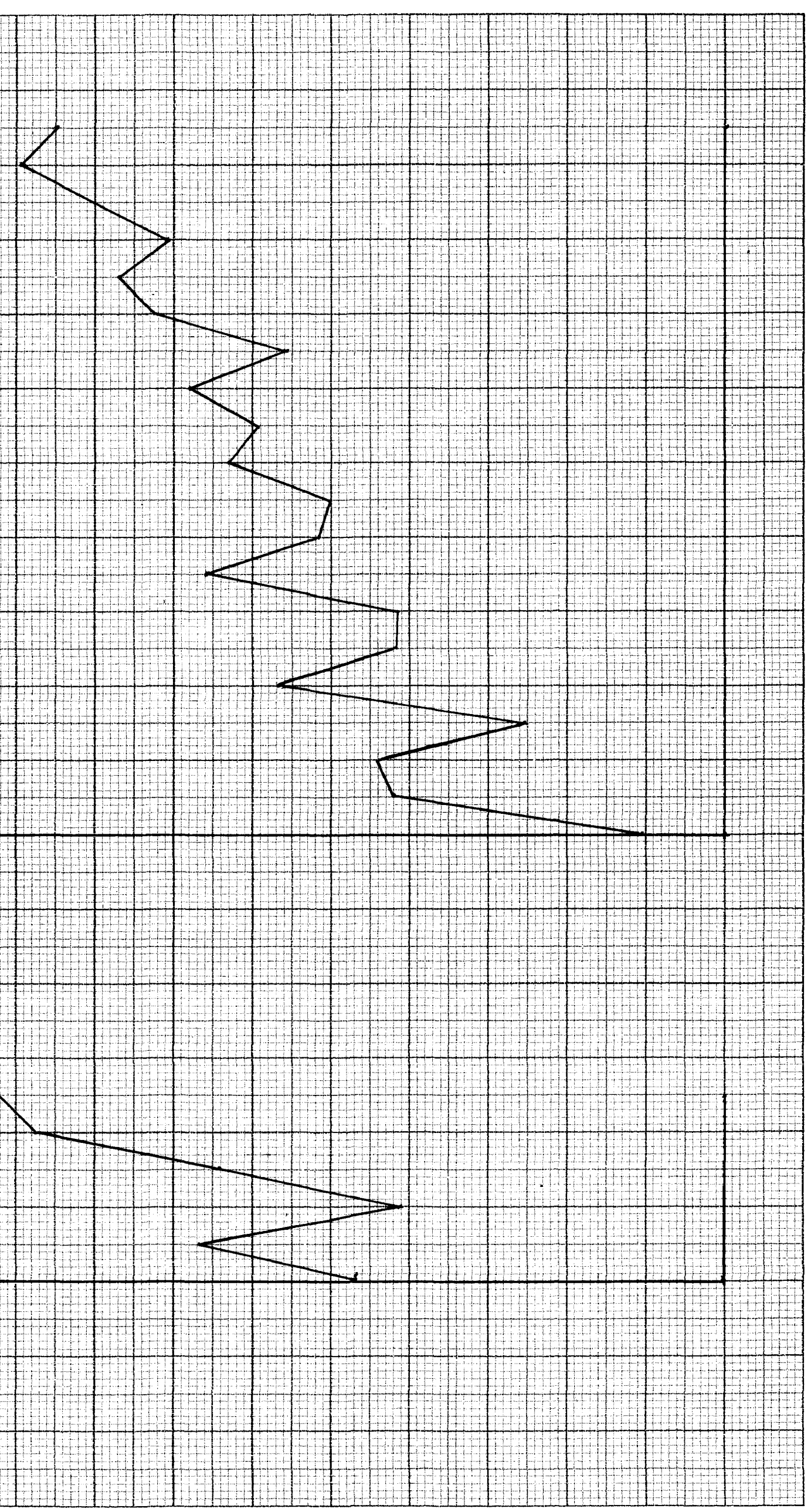


Table 7

Percentages of Error made by 274 Eleveñth Rrode Pupils on six Rules of Capitalizotion and Turenty Rules ap Punctuotion

\begin{tabular}{|c|c|c|c|}
\hline \multicolumn{4}{|c|}{ Copitolization } \\
\hline$\frac{\text { Arode } 11}{\text { Rule }}$ & opporTurition & Number of & 4 Pupil \\
\hline$\frac{1}{1}$ & 1096 & 526 & 47.8 \\
\hline 2 & 3014 & 762 & 25.4 \\
\hline 3 & 1096 & 484 & 44.1 \\
\hline 4 & 1096 & 300 & 37.3 \\
\hline 5 & 1096 & 113 & 10.3 \\
\hline 6 & 1096 & 37 & 3.4 \\
\hline \multicolumn{4}{|c|}{ PunctuATion } \\
\hline 1 & 1096 & 751 & 68.5 \\
\hline 2 & 2192 & 963 & 44.0 \\
\hline 3 & 1918 & 642 & 33.6 \\
\hline 4 & 1096 & 621 & 60.3 \\
\hline 5 & 1644 & 519 & 316 \\
\hline 6 & 1046 & 574 & 44.0 \\
\hline 2 & 1096 & $4 / 2$ & 37.6 \\
\hline 8 & 2192 & 534 & 24,4 \\
\hline 9 & 1096 & 363 & 33. \\
\hline 10 & 1096 & 402 & 37.7 \\
\hline 11 & 3288 & 860 & 26.3 \\
\hline 12 & 1096 & 358 & 32,5 \\
\hline 13 & 1370 & $3 / 1$ & 222 \\
\hline 14 & 1096 & 388 & 35.4 \\
\hline 15 & 1918 & 332 & 17.8 \\
\hline 16 & 1644 & 256 & 15.2 \\
\hline 17 & 1096 & 187 & 17.1 \\
\hline 18 & 3014 & 376 & 12.5 \\
\hline 19 & 3288 & 174 & 5.3 \\
\hline 20 & 1096 & 131 & 20 \\
\hline
\end{tabular}




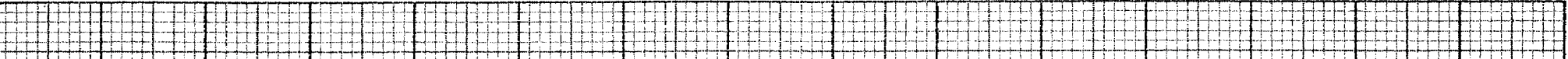

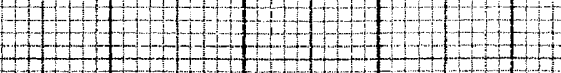
$++1+++1+1+10$

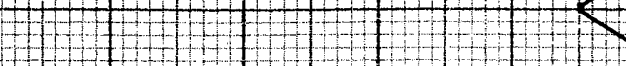

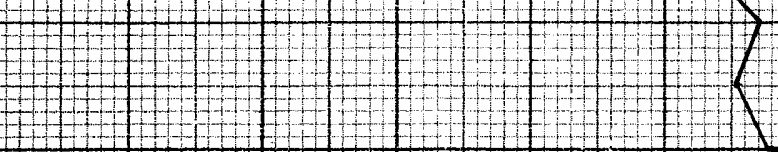
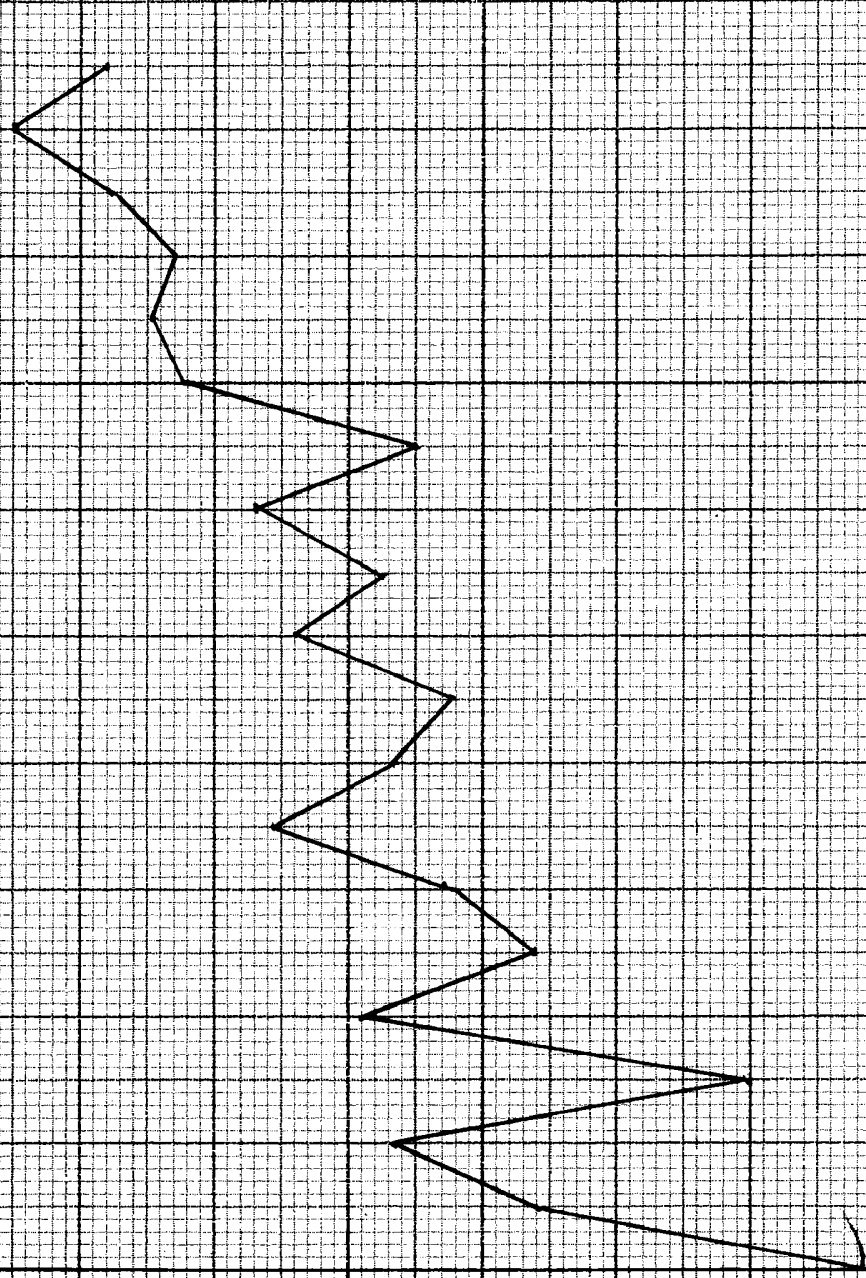

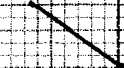

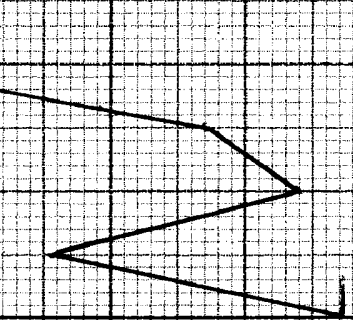


used oexreotly as aften as four times in ton opportunit4es. One rate (mober 2) is used cexreotzy only woe in every two hundred opportunties. Ony rive raies axe ueod eorreotzy twe times in erery ten oppertunties.

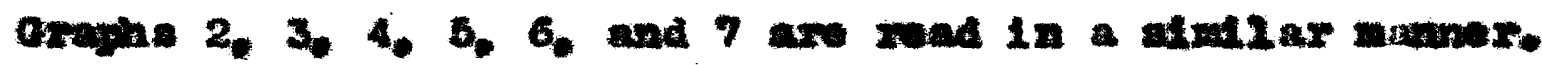

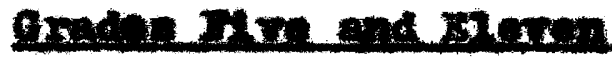

The gain in punotuati on and oapl talizati on abluHes Irom exades Ifre to cleven is prevented in Graph

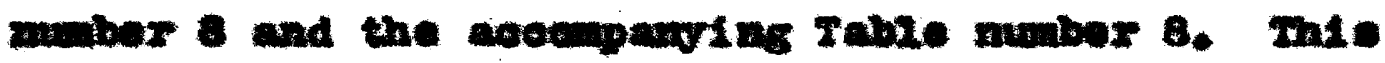
croph and table acming the rosulte edron in Graphe

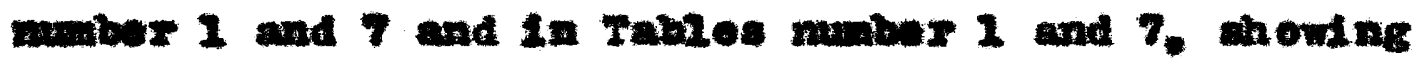
porvontages of exroxs ande by If rth and aleventh grade pupti: sempeotitrely.

In oapt tallesti on and punotuati on tegether the average porventag of error has been dimintibed from grade 5 to grade 11 by $5.8 \%$ the are zage oapltallzati on perventage of exror has been dindin ahed by $43.3 \%$, and the arerage punetuati on perventage of exror by $54.4 \%$

In eapitall zets on zulo: 5 and 6 have boen reduced te waves negled ble perventages of exror. The erowth in abitty in all ax mues is seep te hawe been unform. If equal Imetrueti onal enghed a has been pleoed on each we. It would appenr that the Arfloulty experienoed in Leaming theos weagen oould be renked in the order of

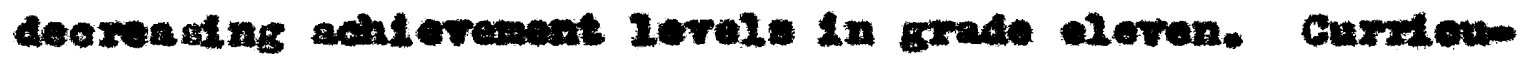

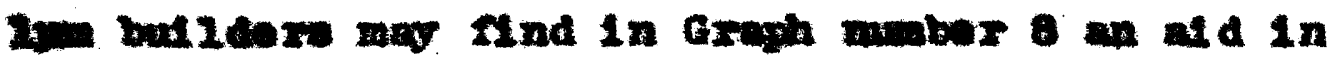


Table 8

Percentages of Errors Made by 100 Fifth Grade Pupils and 274 Eleventh Grade Pupils on Rules of Capitalization and Punctuation

\begin{tabular}{|c|c|c|}
\hline \multicolumn{3}{|c|}{ Capitalization } \\
\hline Rule & Grade 5 & Grade II \\
\hline Number & $\%$ Error & $\%$ Errer \\
\hline 1 & 95.9 & 47.8 \\
\hline 2 & 84.6 & 25.4 \\
\hline 3 & 84.2 & 44.1 \\
\hline 4 & 778 & 37.3 \\
\hline 5 & 65.7 & 10.3 \\
\hline 6 & 19.2 & 3.4 \\
\hline 1 & 99.5 & 68.5 \\
\hline 2 & 978 & 44.0 \\
\hline 3 & 96.9 & 33.6 \\
\hline 4 & 95.5 & 60.3 \\
\hline 5 & 950 & 31.6 \\
\hline 6 & 93.9 & 44.0 \\
\hline 7 & 93.5 & 326 \\
\hline 8 & 90.8 & 244 \\
\hline 9 & 900 & 33.1 \\
\hline 10 & 88.4 & 372 \\
\hline 11 & 88.2 & 26.3 \\
\hline 12 & 85.6 & 32.5 \\
\hline 13 & 854 & 220 \\
\hline 14 & 85.0 & 354 \\
\hline 15 & 83.0 & 17.8 \\
\hline 16 & 78.7 & 15.2 \\
\hline 17 & 75.8 & 121 \\
\hline 18 & 678 & 12.5 \\
\hline 19 & $6 / 8$ & 5.3 \\
\hline 20 & 42.0 & 120 \\
\hline
\end{tabular}



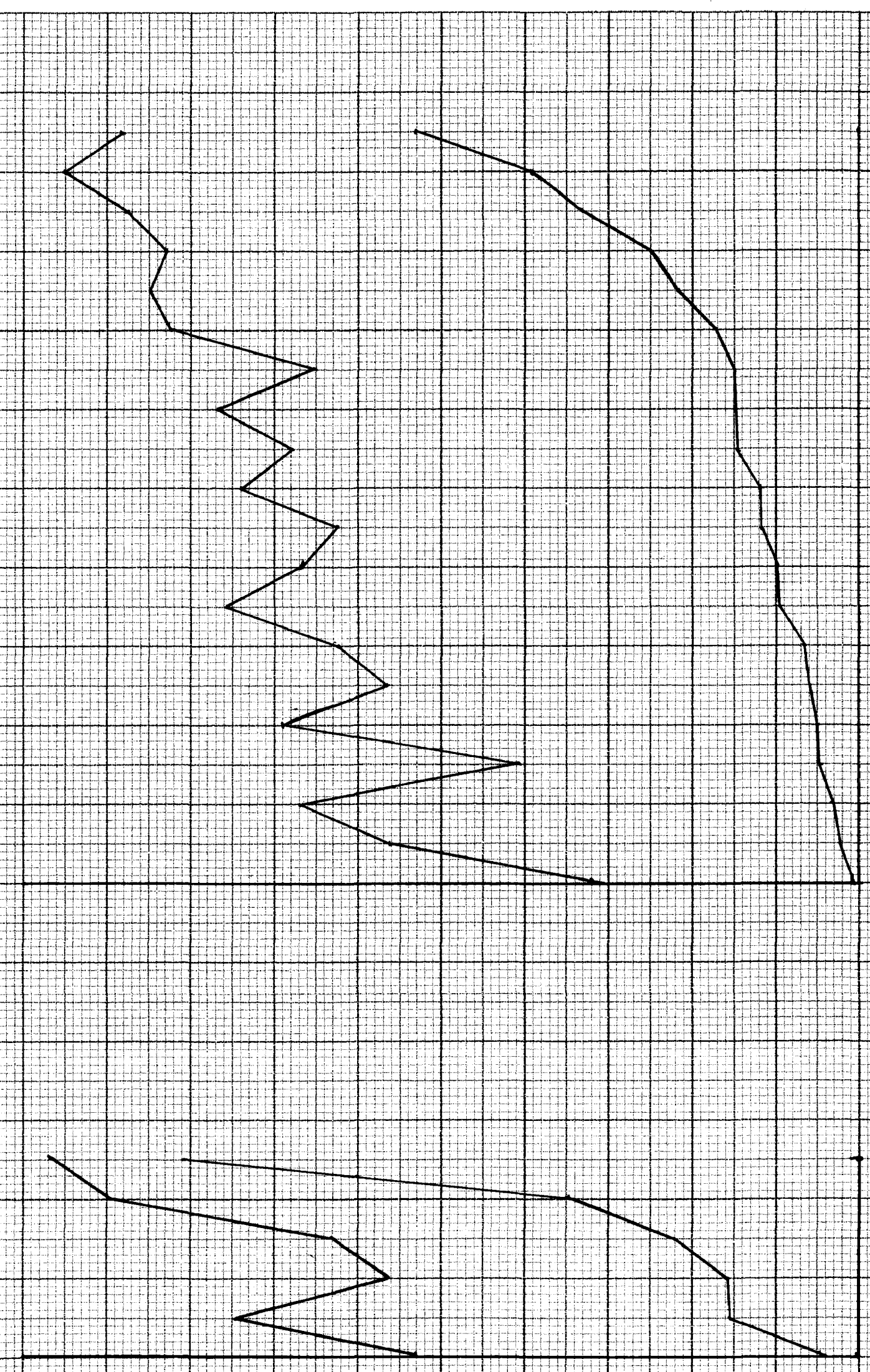
deteratining the empast s to place on these ruies to socure the destred outcones.

In punotuation the growth in ablisty 1 is al so found to be falriy unf form. The general shape of the curve tends to remain the same. The range of percentages is approadmately equal in the se two exrades. The irrogularIty in the upper ourve (eleventh grade) is due in pare to the arbitrary anoothing of the lewer ourve (fifth grade). The author does not attempt to explain the differences in learning rites, but merely to point them out to the reader.

The gain in punotuation and capl talization ablisty frow grade to grade 1 a prosented in both graphlo and tabular form in Graph muber 9, 10, 11, 12, 13, and 14, and in the acoumparying Tables nuber 9, 10, 11, 12, 13, and 14. In each of these graphs and tables the reatute of two adjacent grades aro placed of de by alde to whow the relation between them more alearly.

\section{Gredes mire and $31 x$}

Irom grade five to grade alx (Graph number 9. Table number 9) there is a uniform growth seen in the capttallzati on rules number 2, 2,5 , and 6 , areraging about ef git persent. Fures number 3 and 4 do not mow any appreal able Erowth.

In punotuation the grooth in ablilty raries from ten to twenty poroent in fifteen of the twenty rules. 
Table 9

Percentages of Error Mide by 100 fifth Grode Pupils and 307 sixth Grade Pupils on Rules of capitalization and Purctuotion Capitalization

\begin{tabular}{|c|c|c|}
\hline \multicolumn{3}{|c|}{ Capitalization } \\
\hline Rule & Grade 5 & Grade 6 \\
\hline Number & \% Error & \% Error \\
\hline 1 & 95.9 & 87.2 \\
\hline 2 & 84.6 & 77.6 \\
\hline 3 & 84.2 & 86.0 \\
\hline 4 & 27.8 & 24.6 \\
\hline 5 & 657 & 51.2 \\
\hline 6 & 19.7 & 124 \\
\hline \multicolumn{3}{|c|}{ PunCtUOTION } \\
\hline 1 & 99.5 & 95.2 \\
\hline 2 & 978 & 87.1 \\
\hline 3 & 96.9 & 83.8 \\
\hline 4 & 95.5 & 94.2 \\
\hline 5 & 95.0 & 344 \\
\hline 6 & 93.9 & 91.1 \\
\hline 7 & 93.5 & 89.3 \\
\hline 8 & 90.8 & 223 \\
\hline 9 & 900 & 84.6 \\
\hline 10 & 88.4 & 28.0 \\
\hline 11 & 88.2 & 76.2 \\
\hline 12 & 85.6 & 74.6 \\
\hline 13 & 85.4 & 62.4 \\
\hline 14 & 85.0 & 224 \\
\hline 15 & 83.0 & 68.5 \\
\hline 16 & 28.7 & 69.0 \\
\hline 17 & 25.8 & 649 \\
\hline 18 & 628 & 58.6 \\
\hline 19 & 61.8 & 36.8 \\
\hline 20 & 47,0 & 32.4 \\
\hline
\end{tabular}




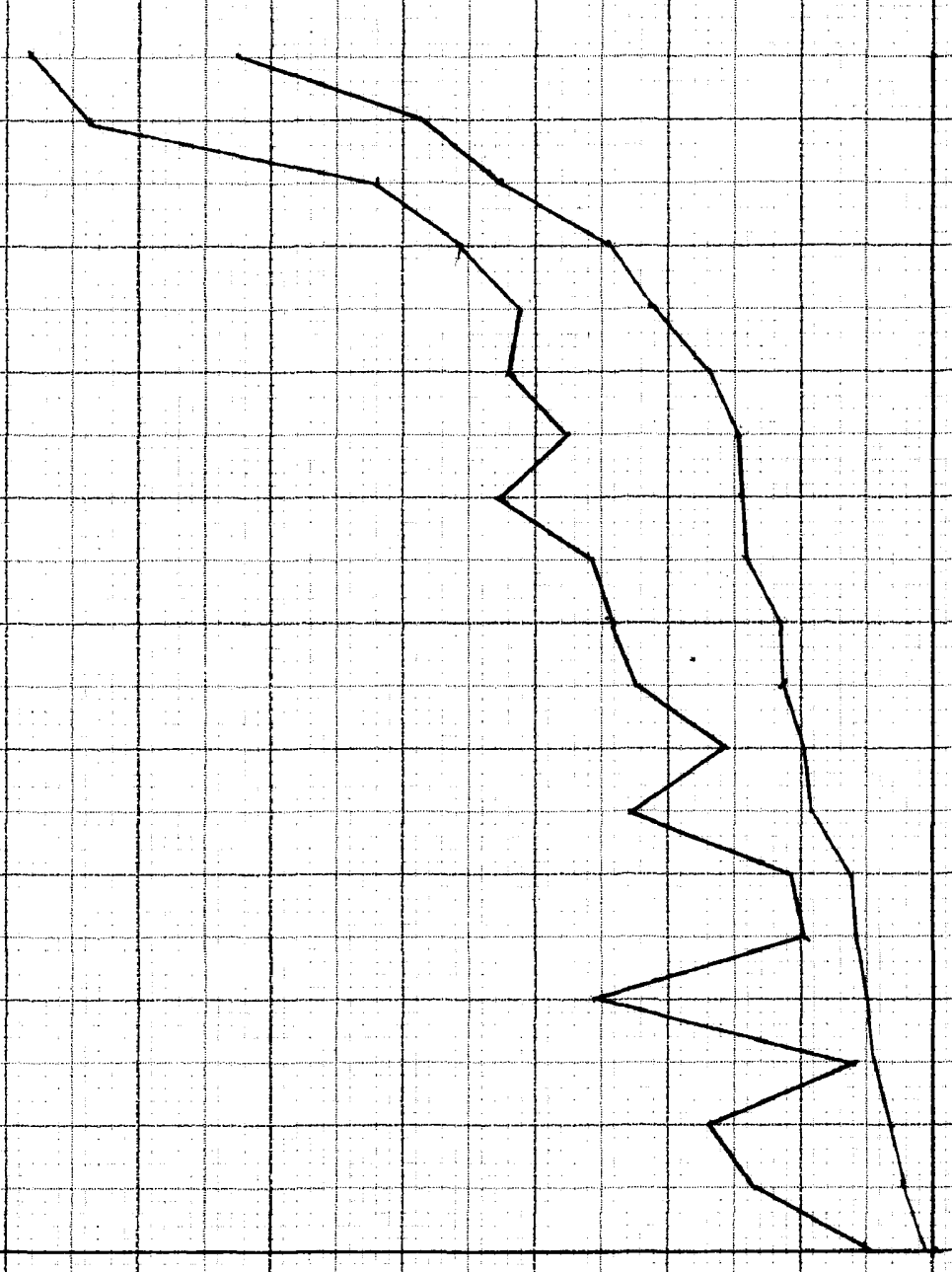


The growth in the meraing five rules varies from one to soven peroent.

\section{Gxidea $31 x$ and seren}

Growth in ability to capi tallze from grades of $x$ to ceven (araph number 10; Table number 10) 18 uni formig rapid. varying frow ten to thirty peroent. Fule mubar 6 I: olosely approaching complete mastery. The growth in punetuation rastes from about ef ght to twenty percent in elghteen of the twenty rules. Te renaining two vary in growth from about 2.5 to 4.4 percent.

\section{araded seren and right}

Approclable growth in ability to oxplallze frem Grades seren to elght (Graph number 11; $T$ thble number 11 ) 1. oonflned to rules number 4 and 6 . There 18 rery 14 tale browth in the romatining four rules.

In punotuation the 1 a rery 11 ttlo erowth. Fures 3. 8, 9, 10, 13, 14, 15, 16, and 20 oh ow wave gatn. In aeveral cases there is a loas in ability indicated. These resulte are most puzzl1ng. They appear to indioate that no learning takes place durlng the second gemester of grade seven and the fl rat semeater of grade elght. Is there oome peoull ar conditi on exd ating in these gradea In the schools repreanted in this study? In there 
Table 10

Percertages of Errors Made by 307 sixth Grade Pupils and 487 seventh Grade Pupils on Rules of capitalization and Punatuation

\begin{tabular}{|c|c|c|}
\hline \multicolumn{3}{|c|}{ Capitolization } \\
\hline Rule & Grade 6 & Grade 7 \\
\hline Number & \%. Error & \% Errer \\
\hline 1 & 87.2 & 73.0 \\
\hline 2 & 72.6 & 60.5 \\
\hline 3 & 86.0 & 76.6 \\
\hline 4 & 74,6 & 45.5 \\
\hline 5 & $5 / 2$ & 28.3 \\
\hline 6 & 124 & 8.9 \\
\hline \multicolumn{3}{|c|}{ Punctuation } \\
\hline 1 & 95.7 & 913 \\
\hline 2 & 87.1 & 24.5 \\
\hline 3 & 83.8 & 81.3 \\
\hline 4 & 94.7 & 84.5 \\
\hline 5 & 74.4 & 54.8 \\
\hline 6 & 91.1 & 72.7 \\
\hline 7 & 89.3 & 69.2 \\
\hline 8 & 27.3 & 54.7 \\
\hline 9 & 84.6 & 659 \\
\hline 10 & 78.0 & 56.2 \\
\hline$\mu$ & 262 & 52.1 \\
\hline 12 & 24.6 & $5 / 4$ \\
\hline 13 & 62.4 & 447 \\
\hline 14 & 72.4 & 48.8 \\
\hline 15 & 68.5 & 43.6 \\
\hline 16 & 69.0 & 46.0 \\
\hline 17 & 649 & 47.0 \\
\hline 18 & 58.6 & 37.4 \\
\hline 19 & 36.8 & 13.6 \\
\hline 20 & 32.4 & 23.1 \\
\hline
\end{tabular}




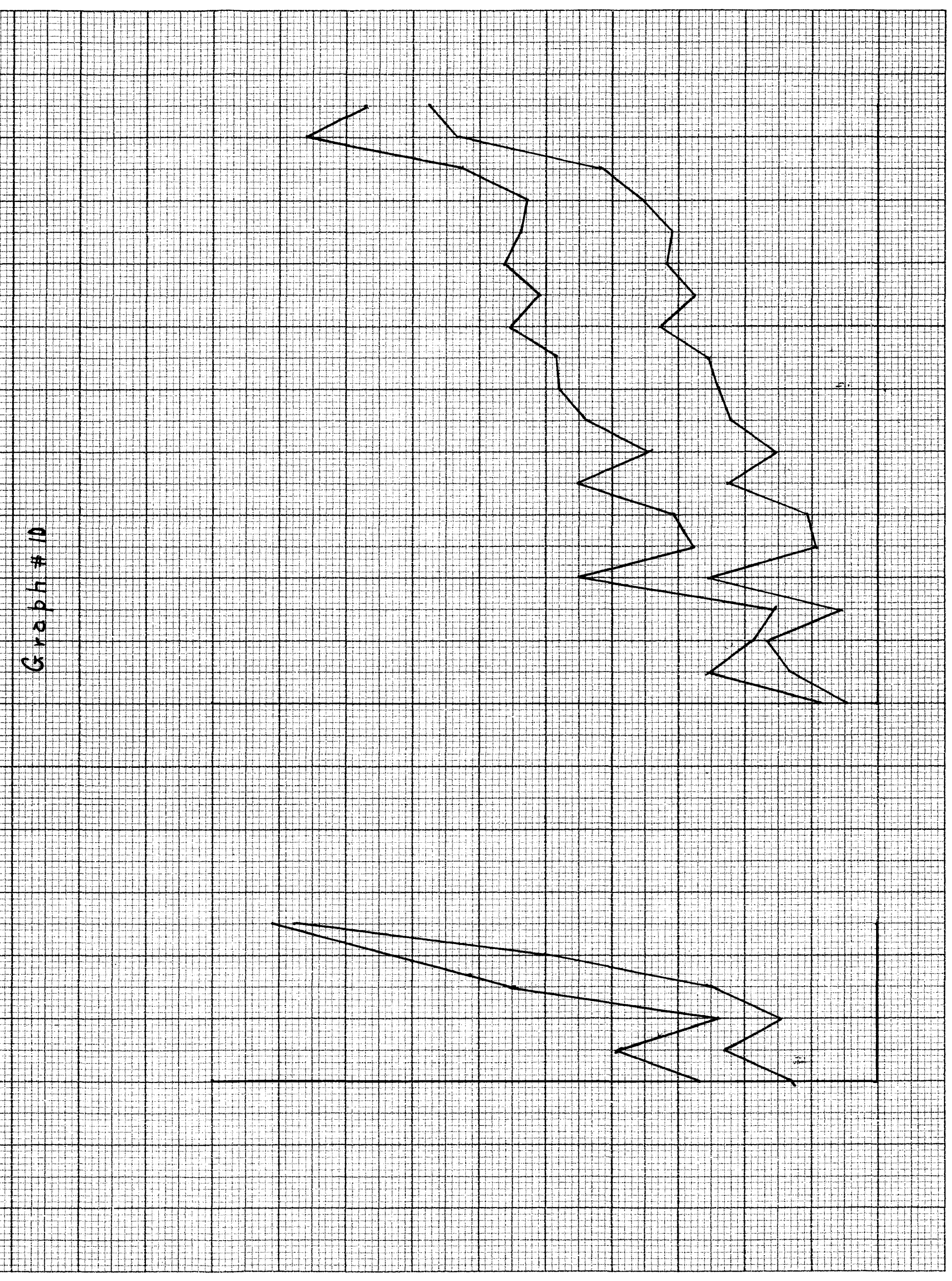


Table 11

Percentages of Errors Made by 487 Severith Grode Pupils and 309 Eighth Grade Pupils on Rules of Punctuation and Capitalizatior

\begin{tabular}{|c|c|c|}
\hline \multicolumn{3}{|c|}{ Capitalization } \\
\hline Rule & Grade 7 & Grade 8 \\
\hline Number & \% Errer & \%o Errer \\
\hline 1 & 73.0 & 71.5 \\
\hline 2 & 65.0 & 58.8 \\
\hline 3 & 76.6 & 25.0 \\
\hline 4 & 45.5 & 55.0 \\
\hline 5 & 28.3 & 31.1 \\
\hline 6 & 8.9 & 18.8 \\
\hline \multicolumn{3}{|c|}{ Punctuation } \\
\hline$\perp$ & $9 / 3$ & 955 \\
\hline 2 & 74.5 & 76.9 \\
\hline 3 & 81.3 & 21.3 \\
\hline 4 & 84.5 & 86.0 \\
\hline 5 & 54.8 & 55.3 \\
\hline 6 & 72.7 & 81.5 \\
\hline 7 & 692 & 78.0 \\
\hline 8 & 54.7 & 46.2 \\
\hline 9 & 65.9 & 640 \\
\hline 10 & 56.2 & 48.4 \\
\hline$\mu$ & 52.1 & 639 \\
\hline 12 & 51.4 & 48.1 \\
\hline 13 & 44.7 & 40.8 \\
\hline 14 & 48.8 & 45.2 \\
\hline 15 & 43.6 & 312 \\
\hline 16 & 46.0 & 33.1 \\
\hline 17 & 42.0 & 44.6 \\
\hline 18 & 32.4 & 35.2 \\
\hline 19 & 13.6 & 15. \\
\hline 20 & 23.1 & 19.5 \\
\hline
\end{tabular}




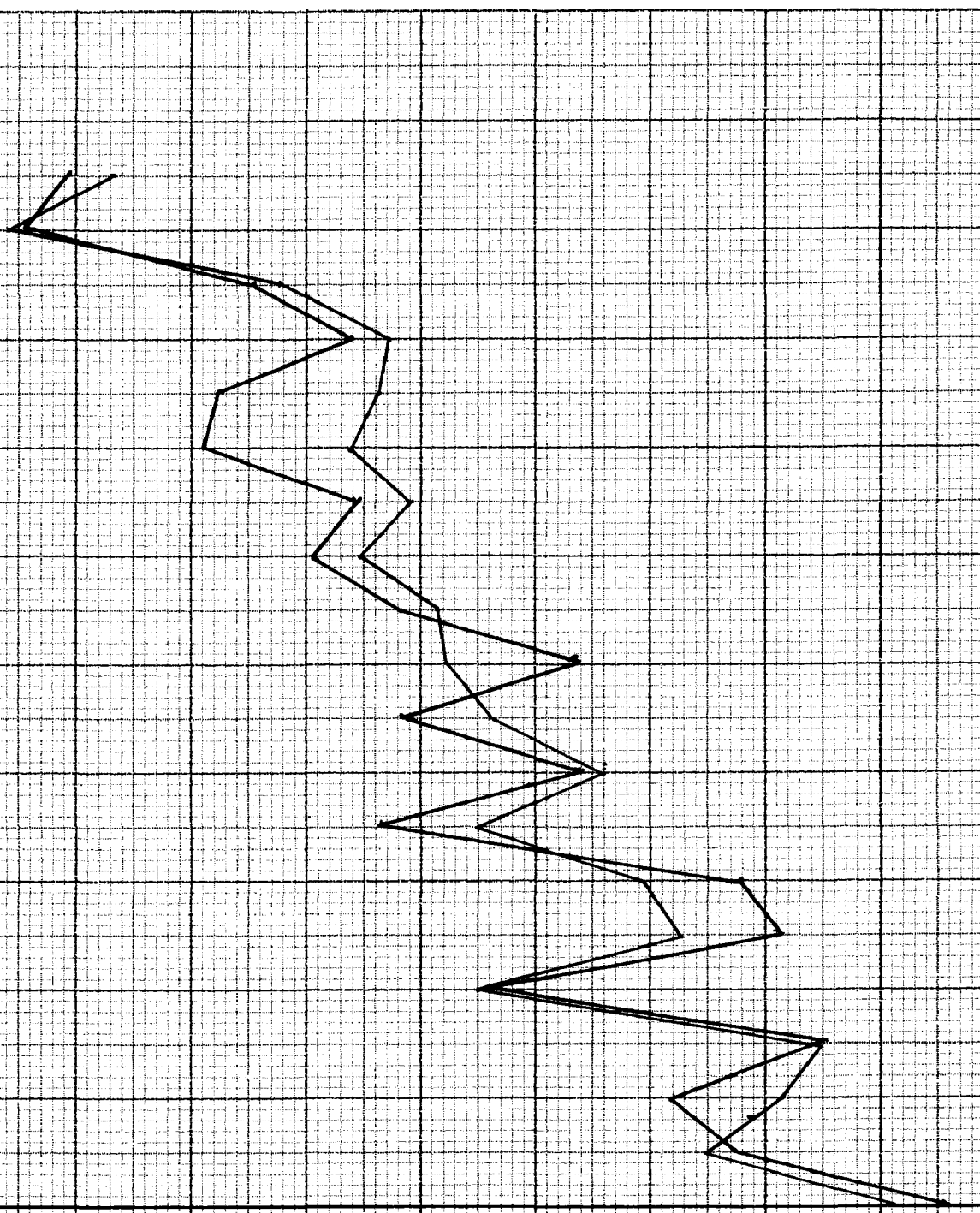




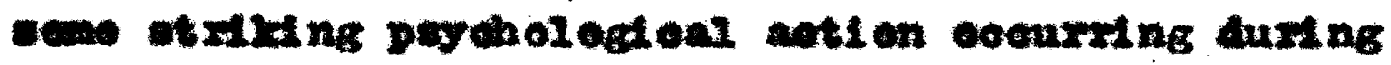

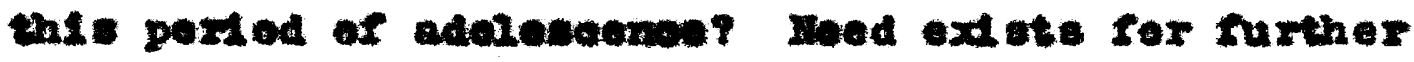

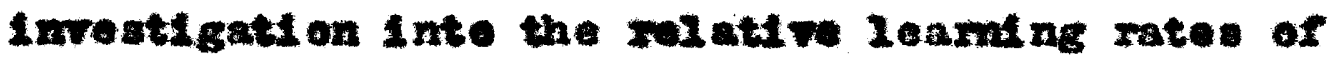
pupila Irom exefte te grade. Ono explanatl on inay be found in the trandtion from the exementary grades to

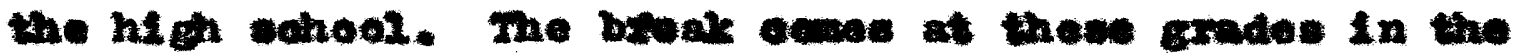
southern ay oteme were part of these remute oome from.

\section{Grodar Btent ma mar}

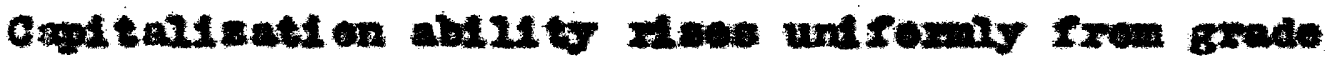

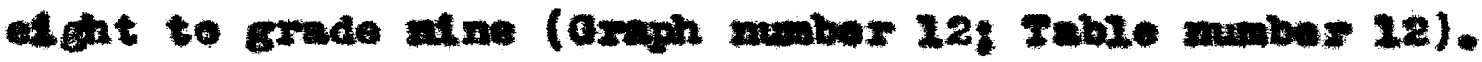
Itre of the atx mules bow an mrexage gatn of about

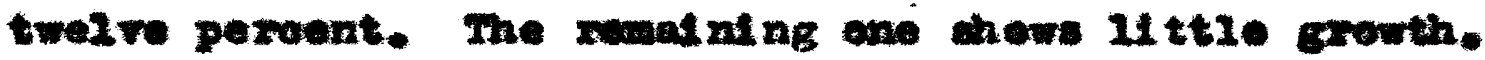
Thex is also a deet ded galn in ablity in the uac

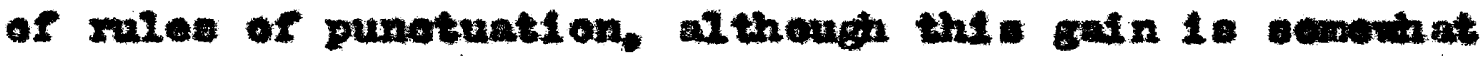
1 moguatar.

\section{Grader me andren}

Orowth in abluty in oapt tallattion fros grades Af to ten (Oxaph muber 23; Table number 13) is woen to be cemparatively 2 arge in twe ruses and amail in the

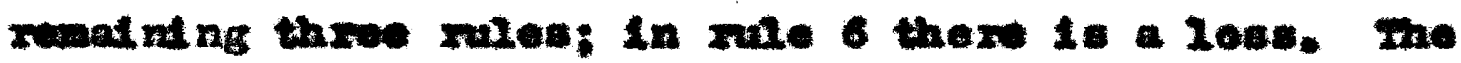
Isox of lange crowth in two of these four walle is probalv due to the aloconese or that $\mathrm{x}$ approach to complete manteryy. 


$$
\text { Table } 12
$$

Percentaqos of Error Made by 309 Eighth Grade Pupils and 312 Ninth Grode Pupils on Rules of Capilalizat ion and Punctuation

\begin{tabular}{|c|c|c|}
\hline \multicolumn{3}{|c|}{ Capitalization } \\
\hline Rule & Grade 8 & Grade 9 \\
\hline Number & \%o Error & \% Error \\
\hline 1 & 715 & 68.0 \\
\hline 2 & 58.8 & 423 \\
\hline 3 & 75.0 & 63.7 \\
\hline 4 & 55.0 & 48.5 \\
\hline 5 & $3 / .1$ & 16.5 \\
\hline 6 & 1.8 .8 & 6.0 \\
\hline \multicolumn{3}{|c|}{ Punctuation } \\
\hline$\perp$ & 95.5 & 83.2 \\
\hline 2 & 76.9 & 65.3 \\
\hline 3 & 71.3 & 46.3 \\
\hline 4 & 86.0 & 27.1 \\
\hline 5 & 55.3 & 39.5 \\
\hline 6 & 81.5 & 64.1 \\
\hline 7 & 78.0 & 56.7 \\
\hline 8 & 46.2 & 37.5 \\
\hline 9 & 64.0 & 486 \\
\hline 10 & 48.4 & 46.3 \\
\hline 11 & 63.9 & 40,2 \\
\hline 12 & 48.1 & 40.0 \\
\hline 13 & 40.8 & 33.6 \\
\hline 14 & 45.2 & 44.1 \\
\hline 15 & 31.2 & 26.8 \\
\hline 16 & 33.1 & 32.8 \\
\hline 17 & 44.6 & 33.2 \\
\hline 18 & 35.2 & 22,2 \\
\hline 19 & 15.1 & 1166 \\
\hline 20 & 19.5 & 11.6 \\
\hline
\end{tabular}



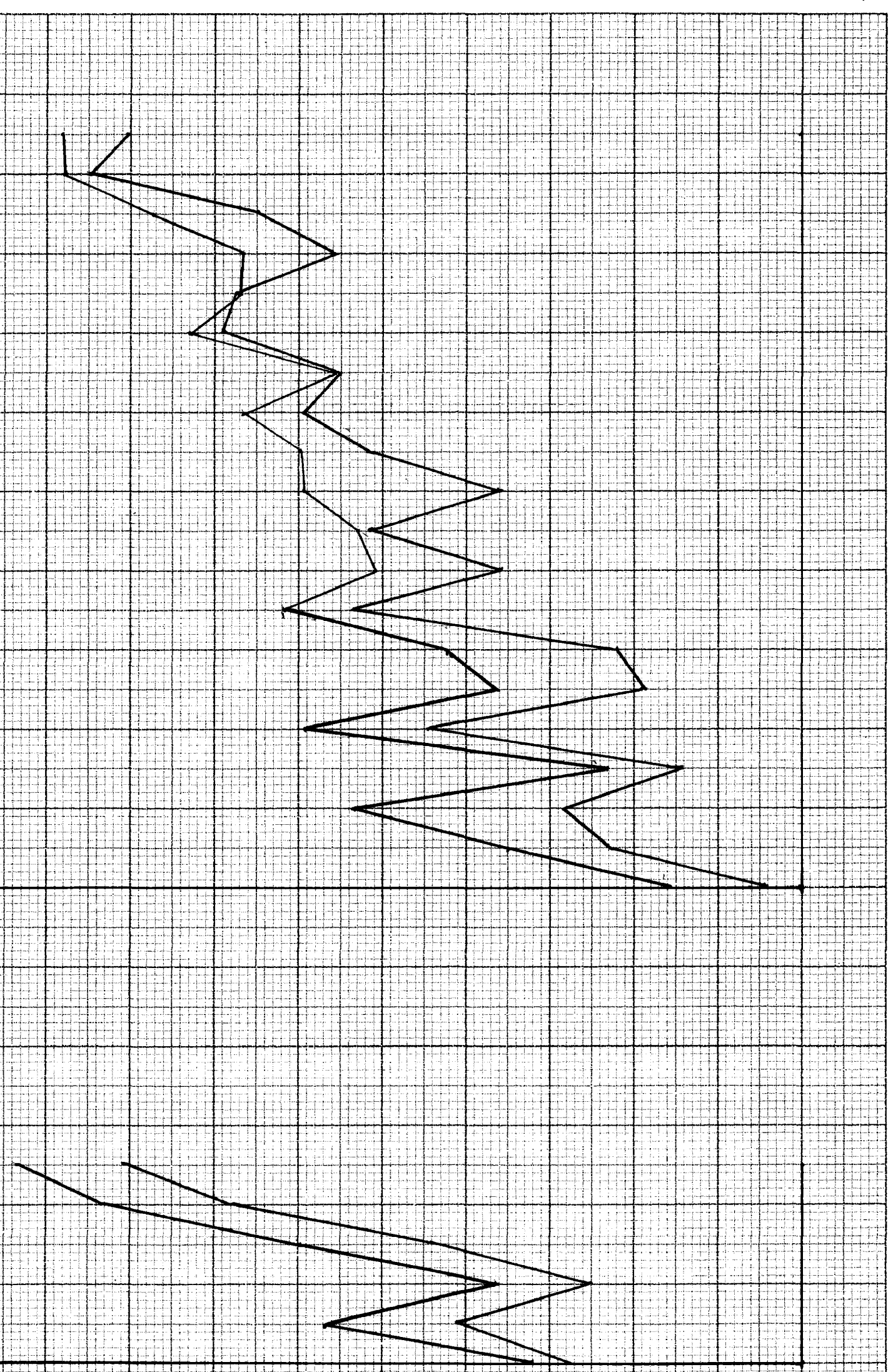
Table 13

Percentages of Errors Made by $3 / 2$ NinTh Grade Pupils ond 266 Tenth Grade Pupils on Pules of Capitalization and Punctuation

\begin{tabular}{|c|c|c|}
\hline \multicolumn{3}{|c|}{ Capitalization } \\
\hline Rule & Grade 9 & Grade 10 \\
\hline Number & To Erer & \%e Errer \\
\hline 1 & 680 & 53.2 \\
\hline 2 & 42.3 & 33.2 \\
\hline 3 & 63.7 & 59.2 \\
\hline 4 & 40.5 & 37.4 \\
\hline 5 & 16.5 & 128 \\
\hline 6 & 6.0 & 7.2 \\
\hline \multicolumn{3}{|c|}{ Punctuation } \\
\hline 1 & 83.2 & 89.5 \\
\hline 2 & 65.3 & 57.8 \\
\hline 3 & 46.3 & 25.6 \\
\hline 4 & 77.1 & 74.3 \\
\hline 5 & 39.5 & 428 \\
\hline 6 & 64.1 & 58.0 \\
\hline$z$ & 56.7 & 58.5 \\
\hline 8 & 375 & 33.7 \\
\hline 9 & 48.6 & 48.1 \\
\hline 10 & 46.3 & 49.6 \\
\hline 11 & 40.2 & 36.8 \\
\hline 12 & 40.0 & 40.7 \\
\hline 13 & 3.3 .6 & $3 / .6$ \\
\hline 14 & 44.1 & 44.0 \\
\hline 15 & 26.8 & 27.2 \\
\hline 16 & 328 & 23.1 \\
\hline 17 & 33.2 & 29.1 \\
\hline 18 & 22.2 & 19.9 \\
\hline 19 & 1166 & 10.8 \\
\hline 20 & 11.6 & 15.1 \\
\hline
\end{tabular}




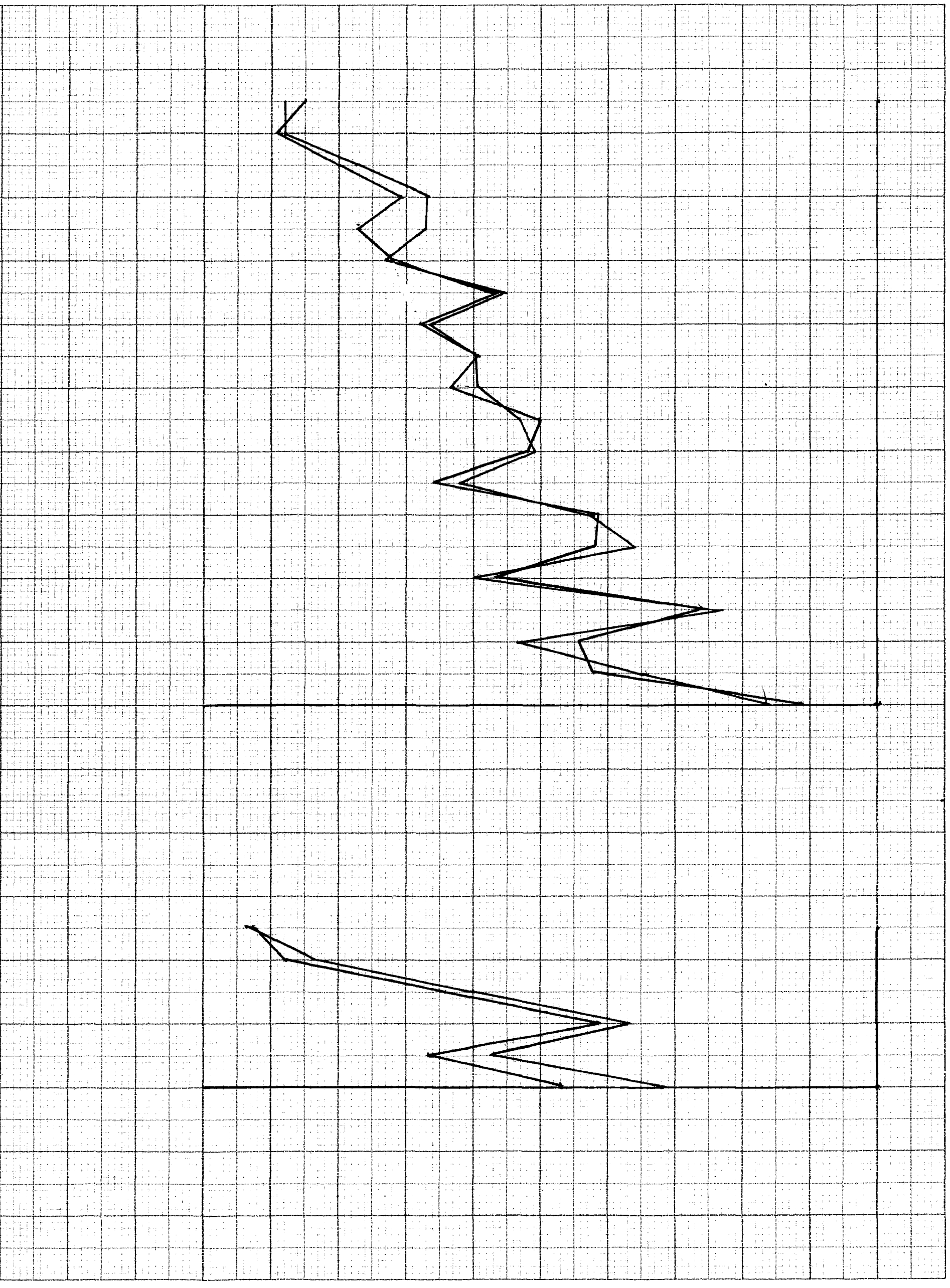


Table 14

Percentages of Errors Made by 266 Tenth Grade Pupils ond 274 Eleventh Grade Pupils on Rules of Capitolization and Punctuation

\begin{tabular}{|c|c|c|}
\hline \multicolumn{3}{|c|}{ Capitalization } \\
\hline Rule & Grade 10 & Grade II \\
\hline Number & \%e Error & Oo Error \\
\hline 1 & 53.7 & 47.8 \\
\hline 2 & 332 & 25.4 \\
\hline 3 & 59.2 & 44.1 \\
\hline 4 & 32.4 & 37.3 \\
\hline 5 & 12,8 & 10.3 \\
\hline 6 & 7.2 & 3.4 \\
\hline \multicolumn{3}{|c|}{ Punctuotion } \\
\hline 1 & 89.5 & 68.5 \\
\hline 2 & 578 & 44.0 \\
\hline 3 & 55,6 & 33.6 \\
\hline 4 & 24.3 & 60.3 \\
\hline 5 & 42.8 & 316 \\
\hline 6 & 580 & 440 \\
\hline 2 & 58.5 & 376 \\
\hline 8 & 33.7 & 24.4 \\
\hline 9 & 48.1 & 33.1 \\
\hline 10 & 49.6 & 37.7 \\
\hline 11 & 36.8 & 26.3 \\
\hline 12 & 40.7 & 32.5 \\
\hline 13 & 31.6 & 22.7 \\
\hline 14 & 440 & 35.4 \\
\hline 15 & 222 & 17.8 \\
\hline 16 & 23.1 & 15.7 \\
\hline 12 & 29.1 & 12.1 \\
\hline 18 & 199 & 12.5 \\
\hline 19 & 10.8 & 5.3 \\
\hline 20 & 15.1 & 120 \\
\hline
\end{tabular}



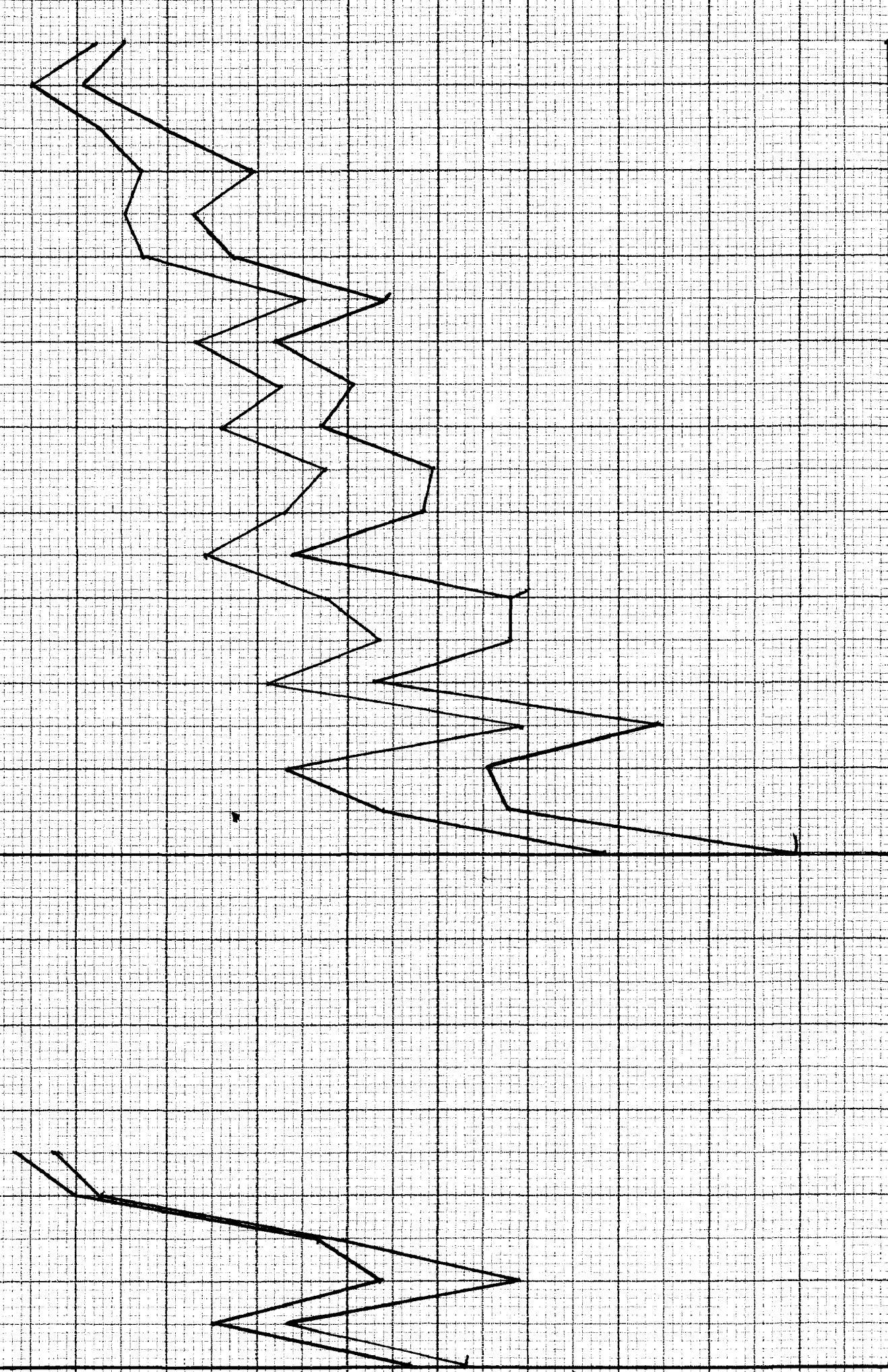


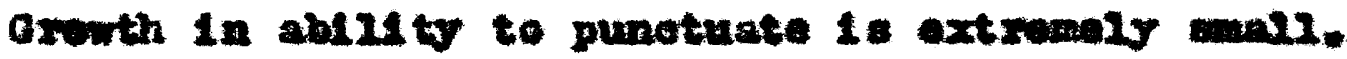

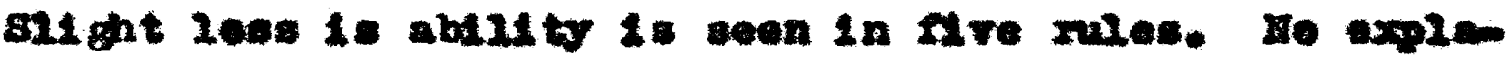

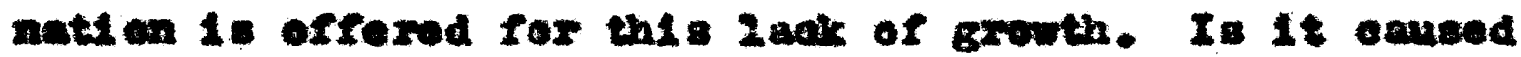
by the ergandzation of the coumes of atudy. the atts-

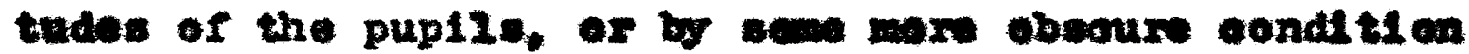

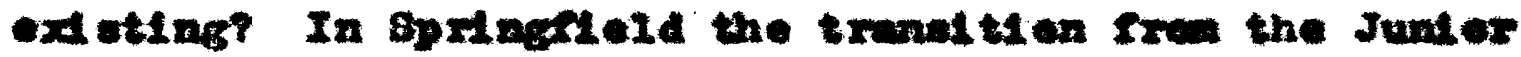
to the Bonler High Bofyed take: place at thes grades.

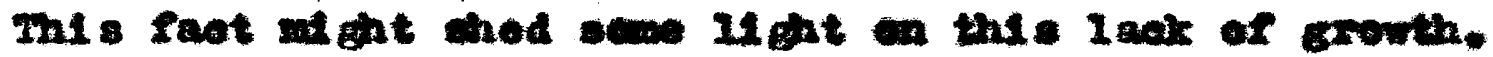

\section{Greden rin te Bram}

Growth in expltalization abilty srom grades ten to eleven (Oxaph nuber 24: Table muber 14) is prosent in Are of the alx xites. Inere appears to bo na gxowth in ane satio.

In propotuation the erowth in ablity if podtive and abotantial. Orvith range frem throe to twanty-two perount. This rapl i Inoxeane in abillty to punotuate appears to Ind oate that the inot ruetional exphant a has been Inoruabed or that there has boen an inoreage in the

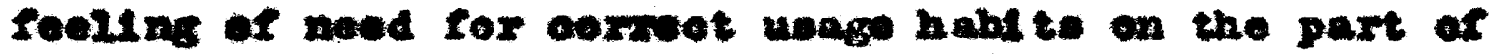
the pupd Is.

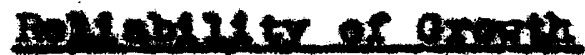

The foregoins analyet of the relative growth in

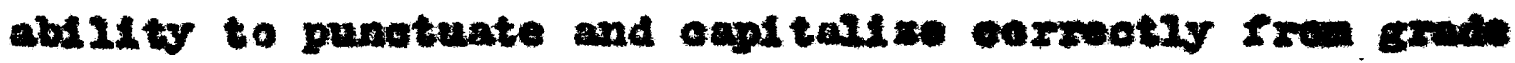
to grade hes thown that erouth rarles. How soll able is the growth from Grade to grade? The stendard deviatiens 
and the meand of the tetal coones made on the mules by grade 1 a needed to Indi oate the mellability of this growth. Pable provides this information for both punotuation and eaplatization in eagh of the grades studied. Keane and sigana were detemined for each grade. A comparian of the neane by grade mows a complete lack of growh frow grades seven to elght in both punotuati on and capitalization. Oxowth in punctun. tlon ability 10 also been to be slor frow grades nine te ten. Gmoth durling the remnining portods 2 seen to be aubstantial.

The 2 arge atgan of the ditiroutions of acores whin ench grade ind eate that there is f largo anount of rarlation in abilt to punctuate and oapltalize between puplis in these Grodes. Tht owoxapplng of ablits reampesies the feot that the se puplis we re unesected wint thel $\mathrm{x}$ ropective grades.

In oxder to determine the rellabluty of the 1 . provement in punotuati on and capitalization ability from grade to Grade (Table D) the following roxmala was applted to the wan and algme wooxan far each Grade:

The Gathe Irom one grade to the next bacomen al griILant as the ratie of the standard deriatione of the difrerunees to the aotual we in approaches 3,0 . This maber is taken to mean that auch inprovement wat due 
Table C

Means and Sigmos

\begin{tabular}{|c|c|c|c|c|c|c|}
\hline \multirow{2}{*}{ Grade } & \multirow{2}{*}{$\begin{array}{l}\text { Nom ber } \\
\text { ppoofonowitises } \\
\text { far Errar }\end{array}$} & \multirow{2}{*}{$\begin{array}{l}\text { Nomber } \\
\text { of } \\
\text { Errers }\end{array}$} & \multicolumn{2}{|c|}{ Mean Percentoge of } & \multicolumn{2}{|c|}{ sigma } \\
\hline & & & cos & Punct & cab & Ponet \\
\hline 5 & 12,494 & 12494 & 23,35 & 102.00 & 6.15 & 15.90 \\
\hline 6 & 46.991 & 3,183 & 17.82 & 87.26 & 7.85 & 1690 \\
\hline 7 & 74,511 & 38,907 & 16.30 & 63.90 & 7.25 & 1620 \\
\hline 8 & 47,277 & 24,315 & 16.90 & 63.13 & 7.30 & 19.20 \\
\hline 9 & 47,736 & 18,921 & $12 / 2$ & 48.31 & 658 & 19.20 \\
\hline 10 & 40,698 & 15,226 & 9.97 & 42.33 & 7.25 & 18.70 \\
\hline 11 & 41,922 & 11,426 & 8.30 & 3360 & 6.54 & 17.40 \\
\hline
\end{tabular}


Toble D

\begin{tabular}{|c|c|c|c|c|c|c|}
\hline \multicolumn{7}{|c|}{$\begin{array}{l}\text { Reliability } \\
\text { Grades } 5 \text {. }\end{array}$} \\
\hline Grades & $\begin{array}{l}\text { Mean G } \\
\text { Lower toh }\end{array}$ & $\begin{array}{l}\text { N from } \\
\text { her Grade }\end{array}$ & & & & \\
\hline $5-6$ & $\begin{array}{l}\text { PunCt. } \\
14.74\end{array}$ & $\begin{array}{l}\text { cop. } \\
5.53\end{array}$ & $\begin{array}{l}\text { Ponct } \\
1.86 \\
\end{array}$ & $\begin{array}{l}\text { cap. } \\
725\end{array}$ & $\begin{array}{l}\text { Puret. } \\
7.22\end{array}$ & $\begin{array}{l}\text { cop. } \\
263\end{array}$ \\
\hline $6-7$ & 23.36 & 1.52 & 1.21 & 514 & 19.25 & 2.96 \\
\hline $7-8$ & .77 & -.60 & 1.32 & 511 & .58 & -1.17 \\
\hline $8-9$ & 1482 & 4.78 & 1.54 & 536 & 9.62 & 9.08 \\
\hline $9-10$ & 5.98 & 2.15 & 1.59 & 551 & 3.76 & 3.9 .0 \\
\hline $10-11$ & 8.73 & 1.67 & 1,50 & 566 & 5.82 & 2.95 \\
\hline
\end{tabular}




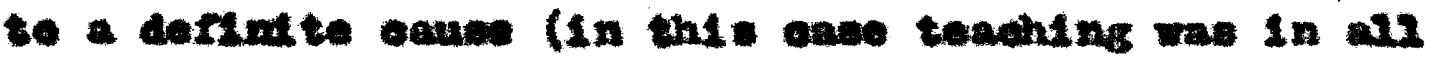
probalulty the chler eauge) and could not have happoned by mero chance.

The celn in punotuation ablity batween ovah two

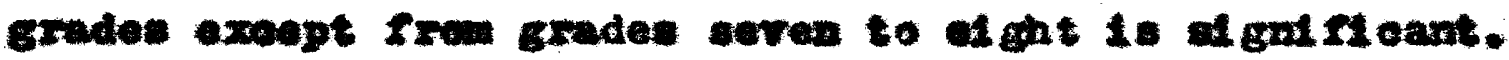
The gatn is eopeod ally al gnisteant betwem grades 24 ve and $4 x_{0}$ at $x$ and seren, and ofit and $\mathrm{min}$. This mov Indl oate that mox exphast is is placed upon ooxroet punotuati on ueage hore then in other grades.

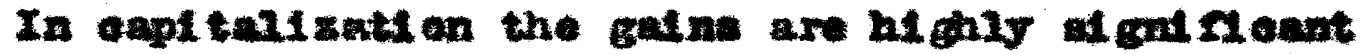

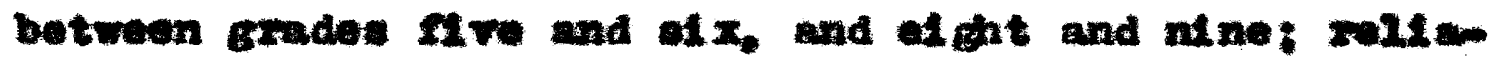
bis af gat fleant botwoen grades wix and seren, nine and ten. and ten and aloven. The gatins betreen grades seven and of ent ax of no signtilanos.

\section{Bextatener of Brax}

The imegulaxty of growth in abilt to to vie oexroet2 the ruies of pubotnati on and copt talizati on ind oate:

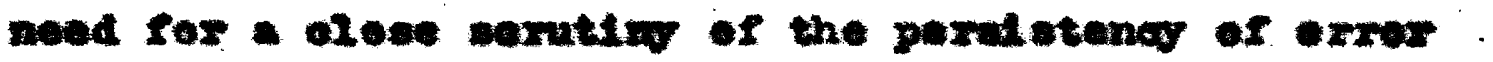
27 each rute from grade to grade. araphe muber 25.26. 27, 18, 19, 20, and 21, and the condpanting Tables maber 25, 16, 17, 18, 29, 20, and 21 d the peroontases of error made on each mat in each of the neven

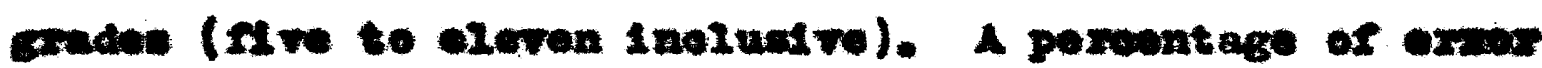

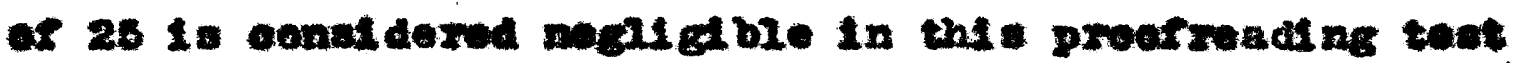

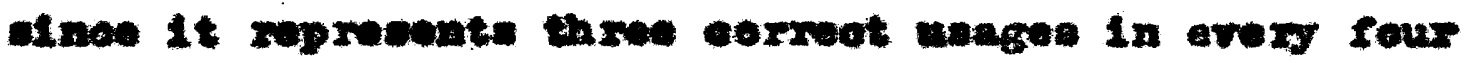




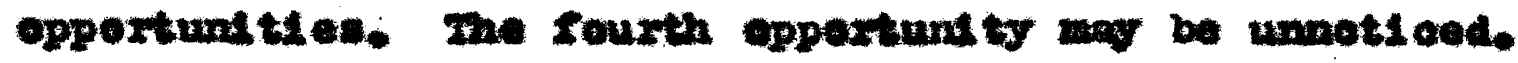

\section{Gantentixatien}

$A$ ponth ourre for each of the zunes or oapl tauke-. tion Io pravented in oroph muber 28.

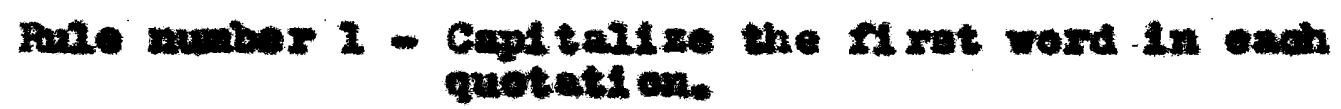

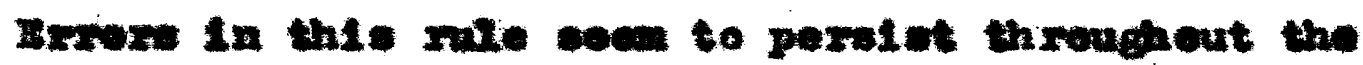

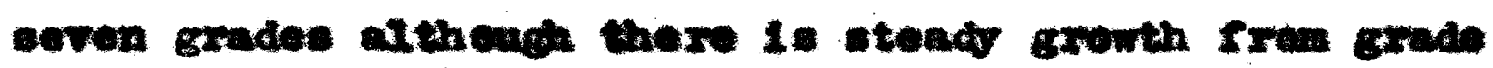
to erade. In grade tive tuili pexoentage of exrer is

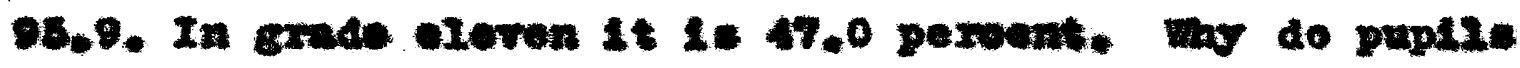

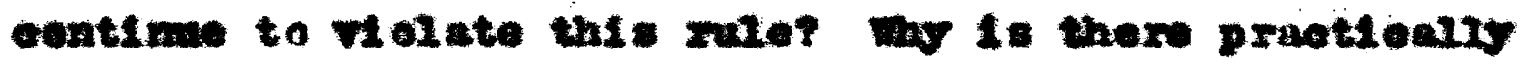
no galn in nbillty to neo this rule oexmotly from gxados enren to biner

Dule maber 2 - Captealise the pxinctpar worde in thes.

The oarve for this one indteates that a high degoo or matexy wer be obtat mod by the and of gxade eleren.

fare nober 3 - Copl tartzo oweh proper adjeotive.

Iarge errers in this usage pexal st until the midale

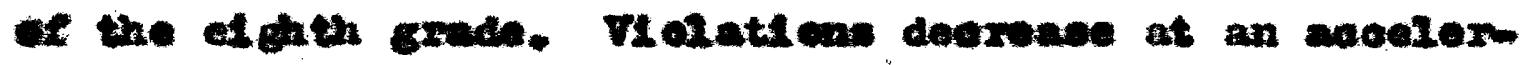
ated rate through the rumelning three crades. There is

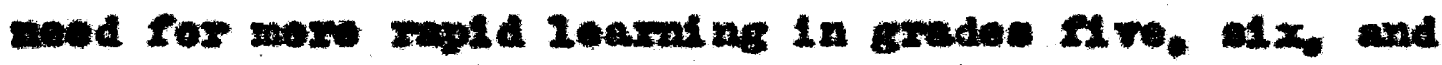
serven.

Fune nuber 4 - Capltallse ench proper noun.

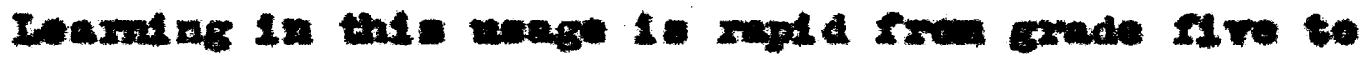
eoven, drope in grade of ent and does not how eroat gatn cuxing the following four grades. Thero is need for 


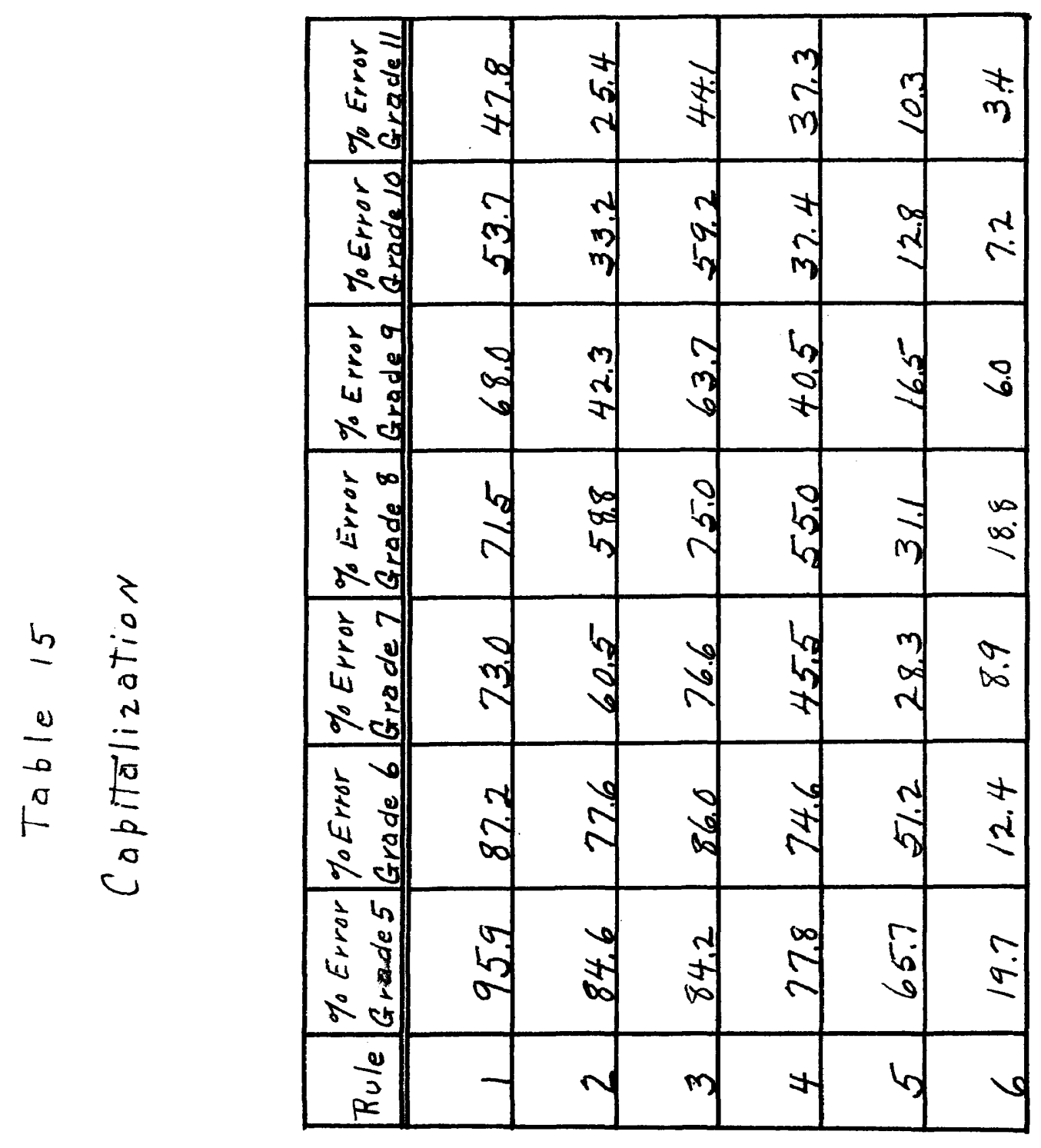




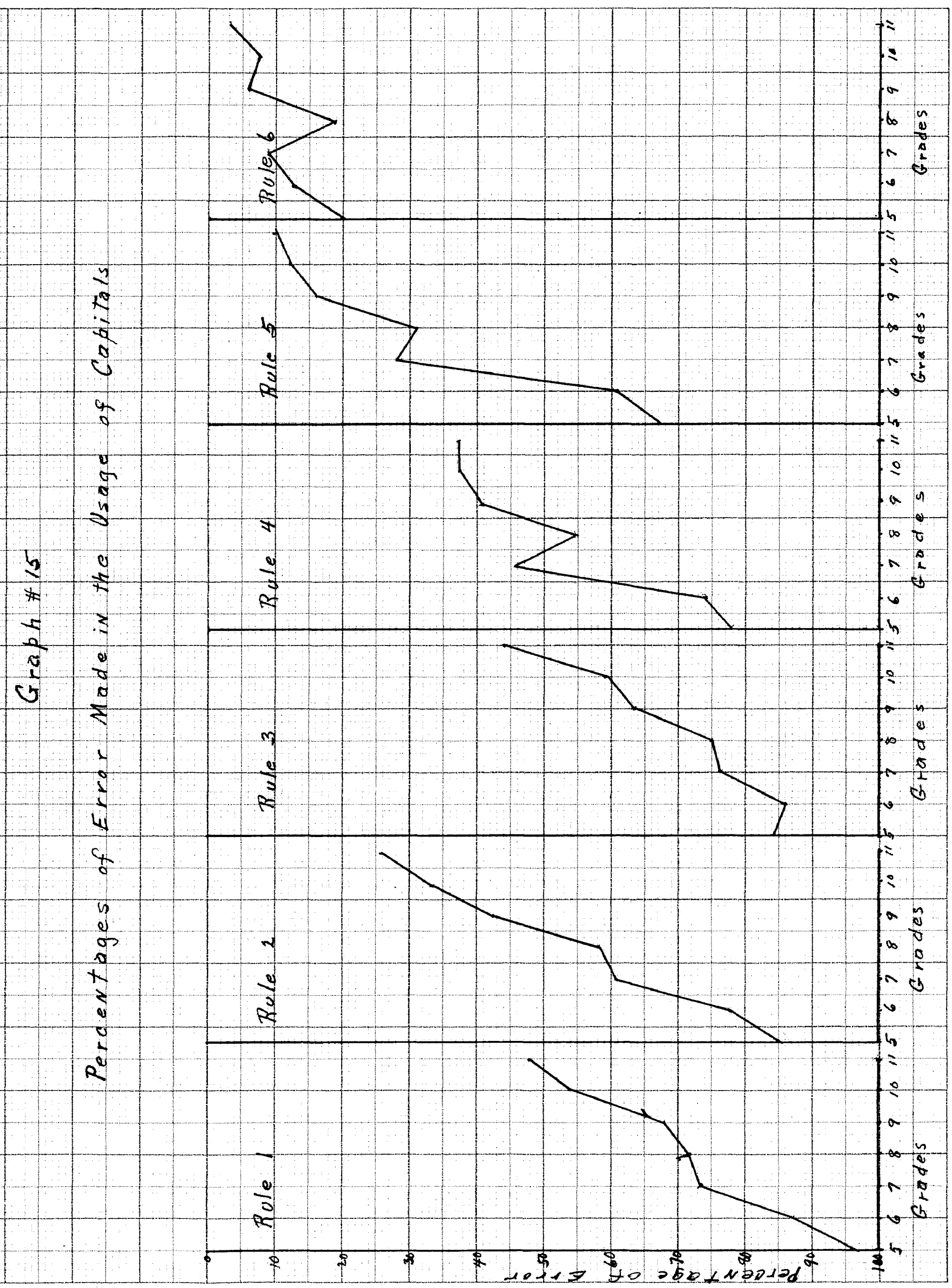


nodele rated Learning from the veronth grade through the exeventh.

Rule number 6 - Capitalise the prenoun "I*.

Grentit in abuty in thio uage is raphe after the Anth srade.

Rule maber 6 - Captenul the the fi rot word in eech

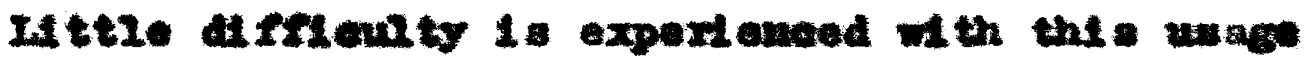

In ary grade. An Intexesting bbervation is pertinom

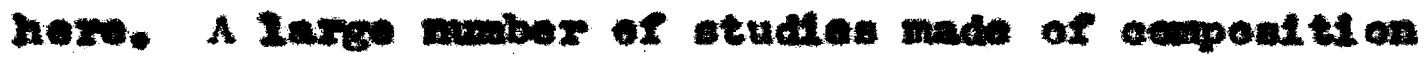

errore Indteate that this mis is rex froquenty No-

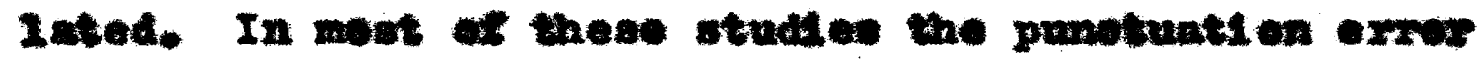

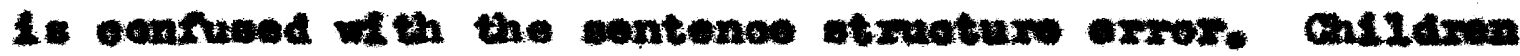

lenow the oapltalization wile but ax froquentiy net able to reagatze the sontence of they oupt tailze the wrong word.

\section{Bundenater}

A Growth oume for enen of the sures of punotuatton If presonted in exphe mmber 16, 17, 18, 19, 20, and 2t.

\section{The erans}

Arowth enrves for each of the ten rulee conoeming seman usage are presented In Gxaph muber 16 and 17.

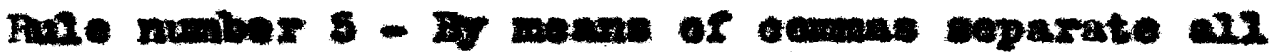
A mot quotations from the reat of the sex matter.

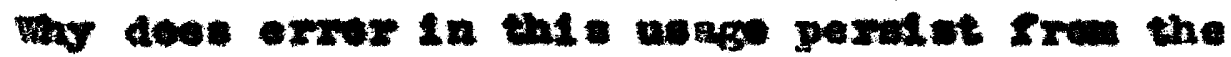




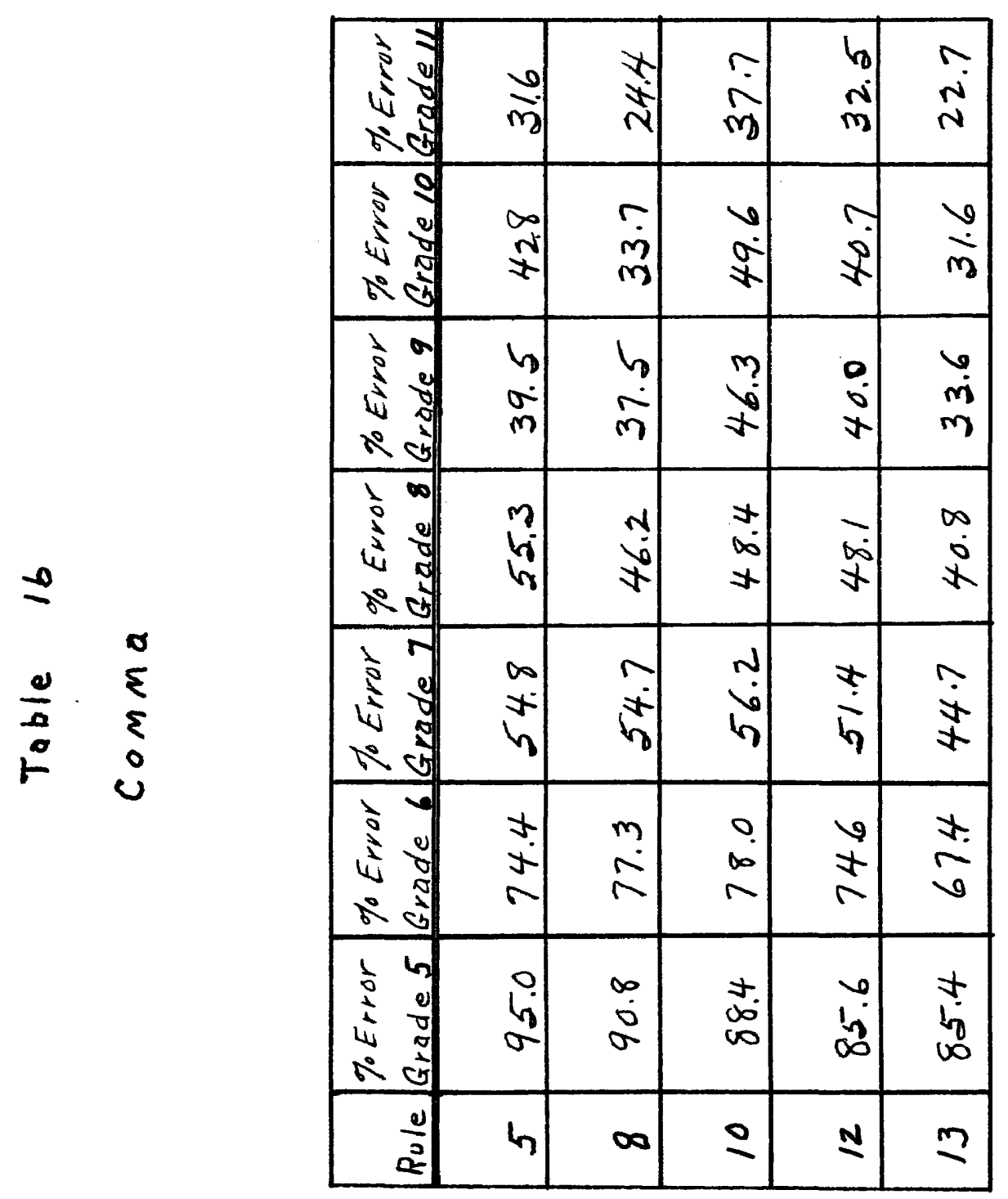




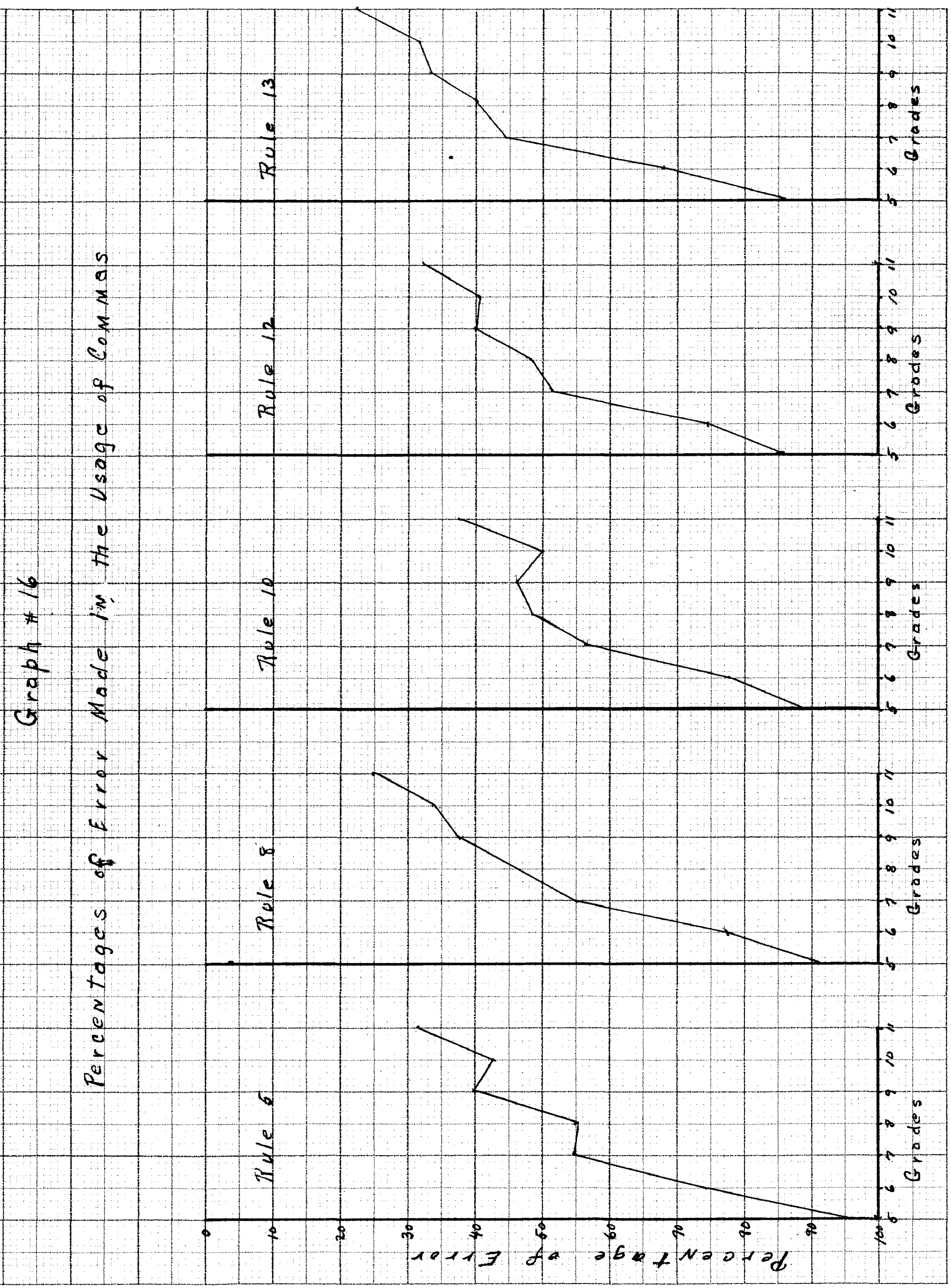


serenth to the of inth grades and agatn frem the nfinth to tho tenth gradoar Thex is a oubetants al caln ahoma durling each of the other grndes. Heed extate for an inoreased rate of learning frem grades aven to of int and rrem atio to ten.

Rune number 8 - Soperate parenthotieal expreant on frum the text matter by comen or deches.

Pup12. appoar to expextenoe 21tt2e affeculty in leaming this usage.

Pule muber 20 - Plage a obra before "mach as" mon ueed in a montenos to Interrupt the prinotpal thougt or then ued appoat tivet or parenthetiealiy.

grrer in thl s usage dinfint hes raptay from crades five to alght. Iobs in amilty is notioed from graden of ont to ten. It peral stenos, breake chaxply in the final perted, from grades ten to elerven.

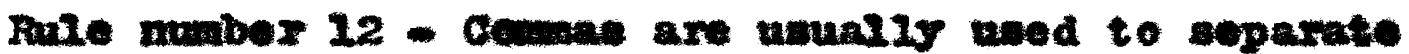
Indopendent olatues that are joined w wuch boexdinating oonjunoti on

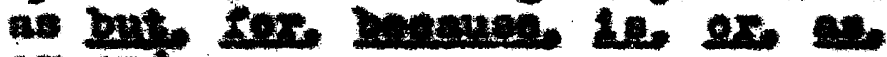
or $2 \mathbf{n s}^{\mathrm{s}}$

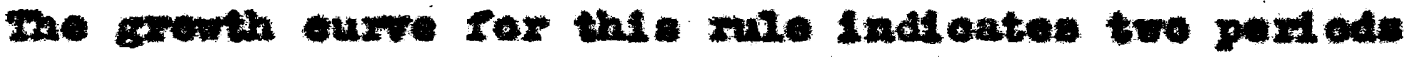

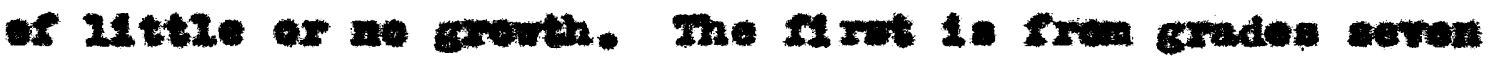
to ef ont and the aboend Irom eradoe nim to ten. The charactextaties of this eurve are rexy atmilar to the cae for zule nuber 5. What 1s the reasen for greater parit stenee of errers during thew pertede?

Fate muber 13 - Set off bo ecmen the name of a perroen adareoved.

Ittie diffieutty io experienoed in learning the eorwes neage of thi s rute from exades five to seven 


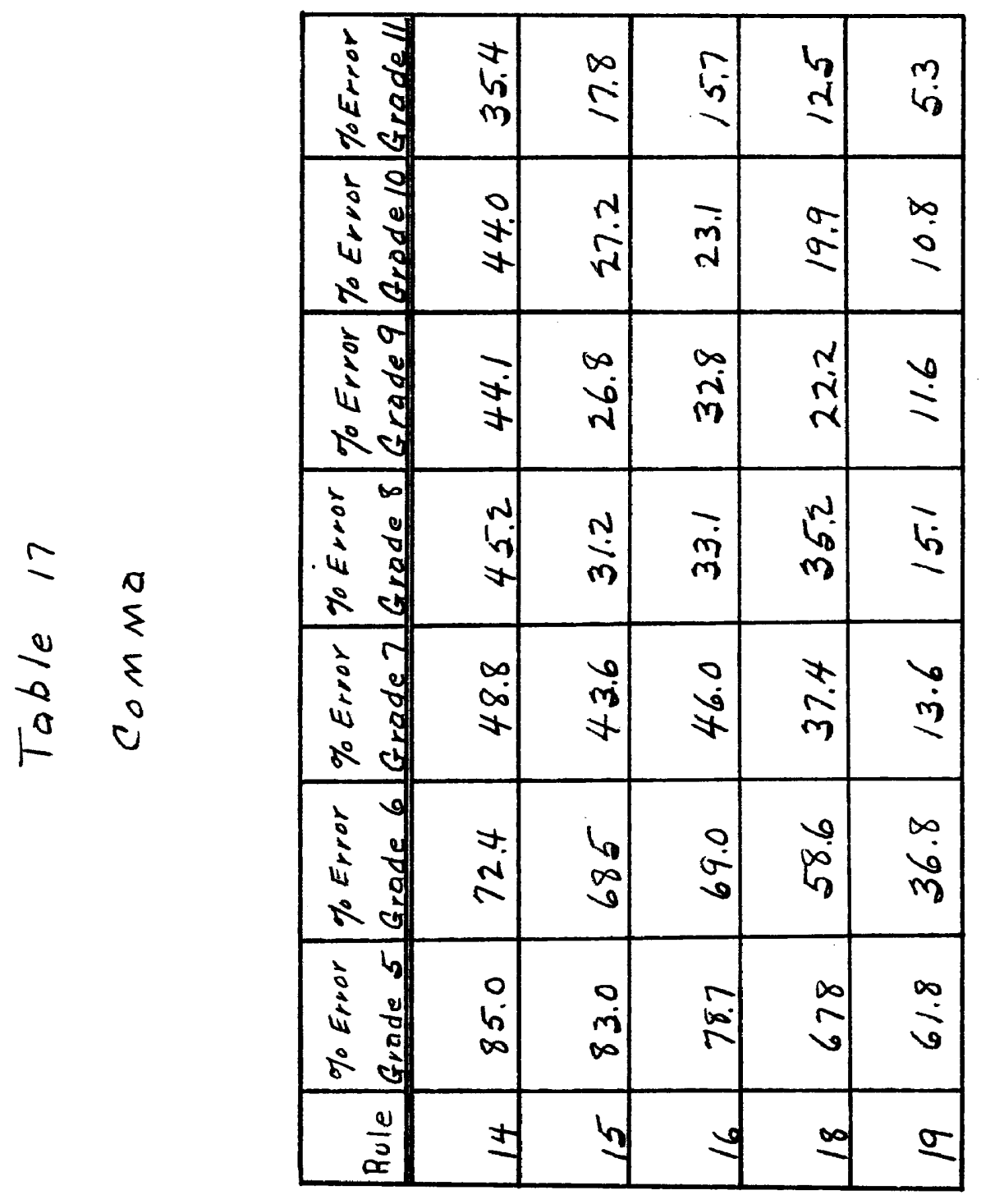




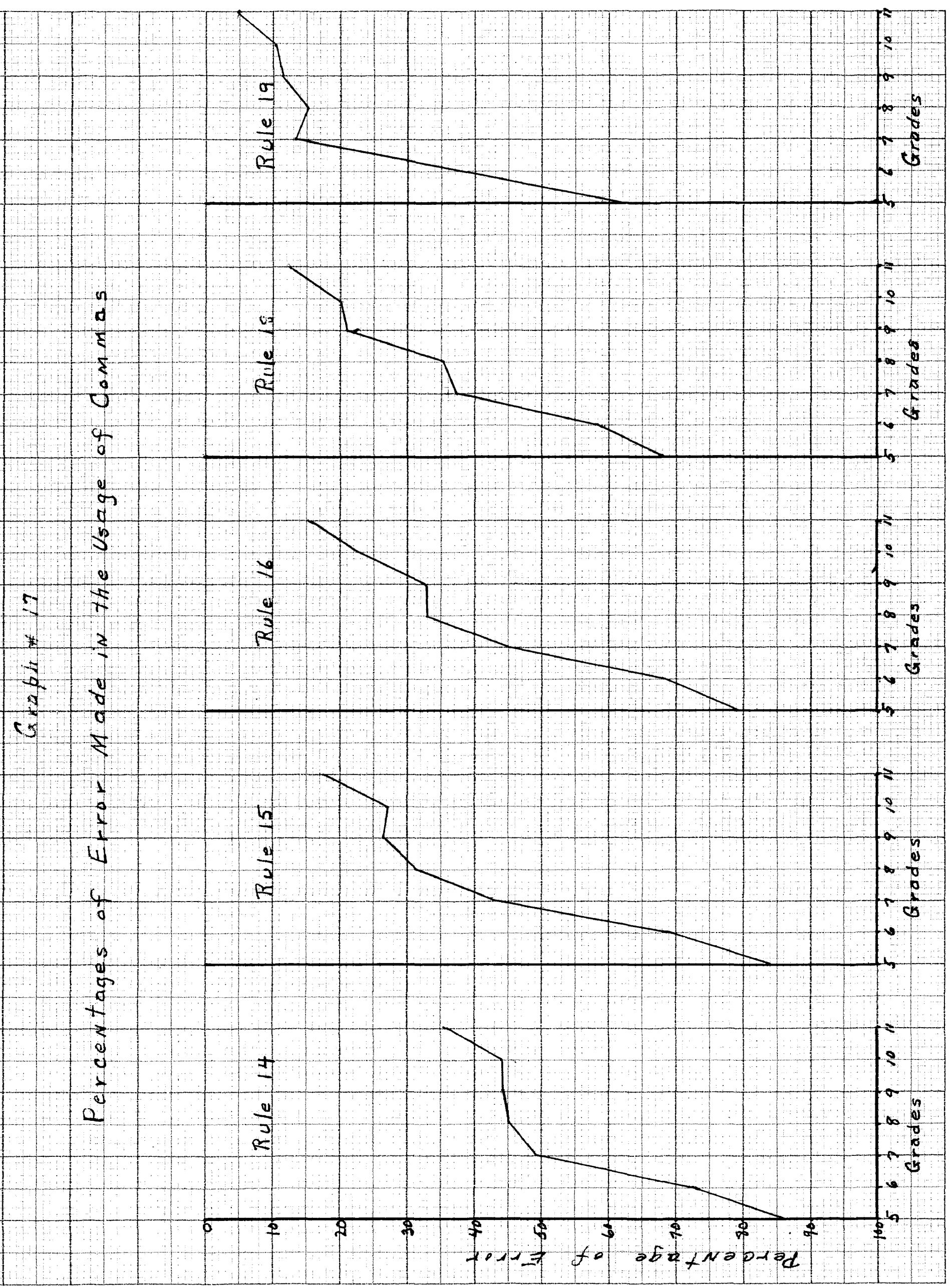


and from grades ten to elevon. grrex does poral at somerinat rrou Exaden seren to ten.

Rule muber 14 - men a vuberatuate olanse proeedes

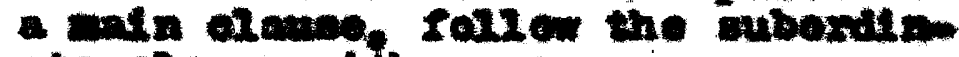
ate a ause ith a omast.

The grouth eurve for thi rule rlae rapidy fru the fifth to the seronth grades. Iren the eventh to the teuth grade very Iftie learning is indieated. In the 2ant poxted. frow the tonth to the eleventh grade a rapha

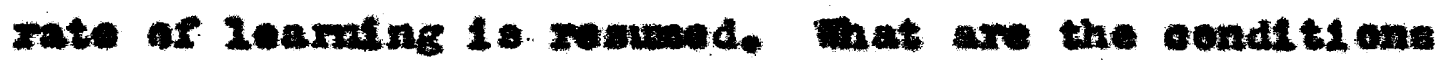

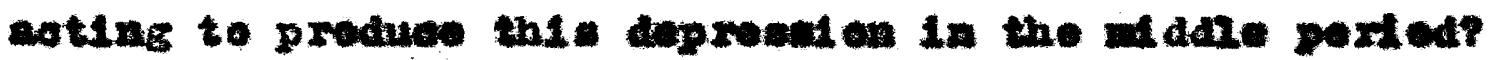

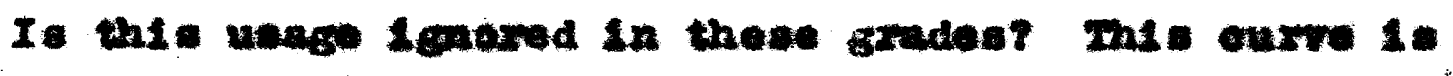

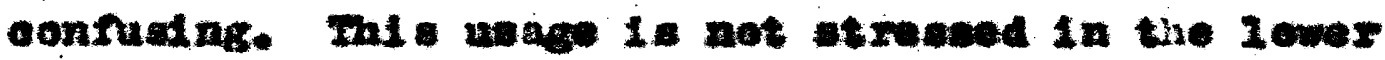
srades, wor the learning is rupte but is etreesed in

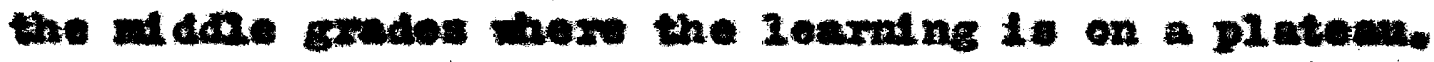

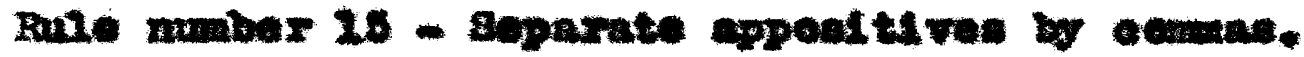
Ifttis difrieulty is experienoed in learnt nis the oernut neage of this ruie except botreen grades nine and ten.

Fule muber 26 - Set off soetzlath ve olmues and phraees by ecmane.

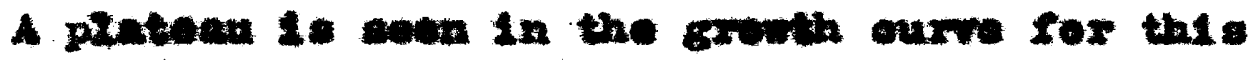

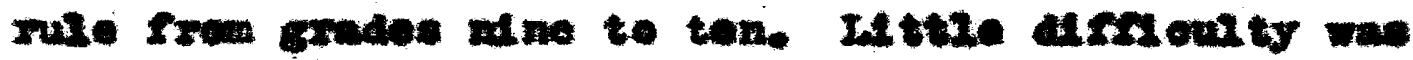
expertenesed in ether grades.

Fure maber 28 - Uee a obme to ot af the name $\alpha$ - atate $8 \pi \times$ the now of $=$ pleoe whin a atnte, atreet from a ats. the reat from the des of the mentik. place 2 ren ate or aneo rim alace.

mis whe proented uthie armovity. Wthoup 
thex were elumpe in growth from the soventh to tho Agth ctrades and from the ainth to the tenth grades.

Hale muber 20 - Uee curan to separate woxde, phrases, and artuese in sextos. and pat a oemeng before "and" wen it is uned to join the last tre 1 tems of the airles.

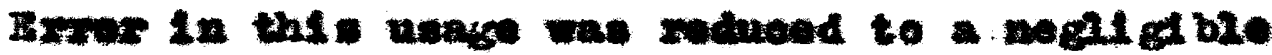
monnt by the aldete of the sereath crade.

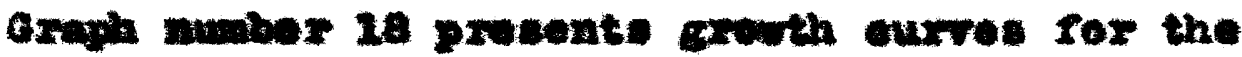

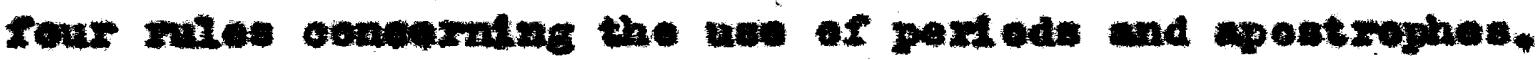

\section{The roxion}

Tule numbr 3 - Place a pexted arter cach abbrordem tion or int tial.

The growth ourve for this rule chows tempoxary deexease in learning rate fru grades wx to seren, Im

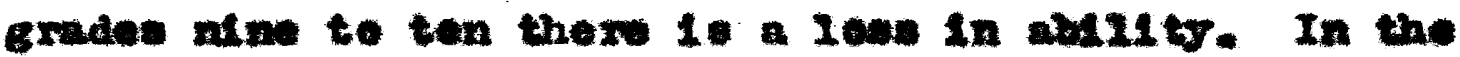
Anel portod, from crades ten to eloven, the learning rate is raptd. Why coes ability to use th1 g rule doorease from erades mine to ten?

Tuze number 20 - Place a pratiod at the end or a declarati $r$ of imperative entenoe.

W tele arrienty was experienced in learning to wee this mie oexrootiy. The confurion ofted in the uee or the perted to ond a eanteno is almizar to the one

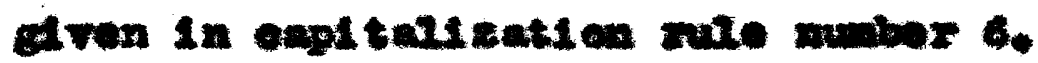

\section{me sperating}

Fule muber 4 - Den the epentrophe to bew the posesentre of a noun. 


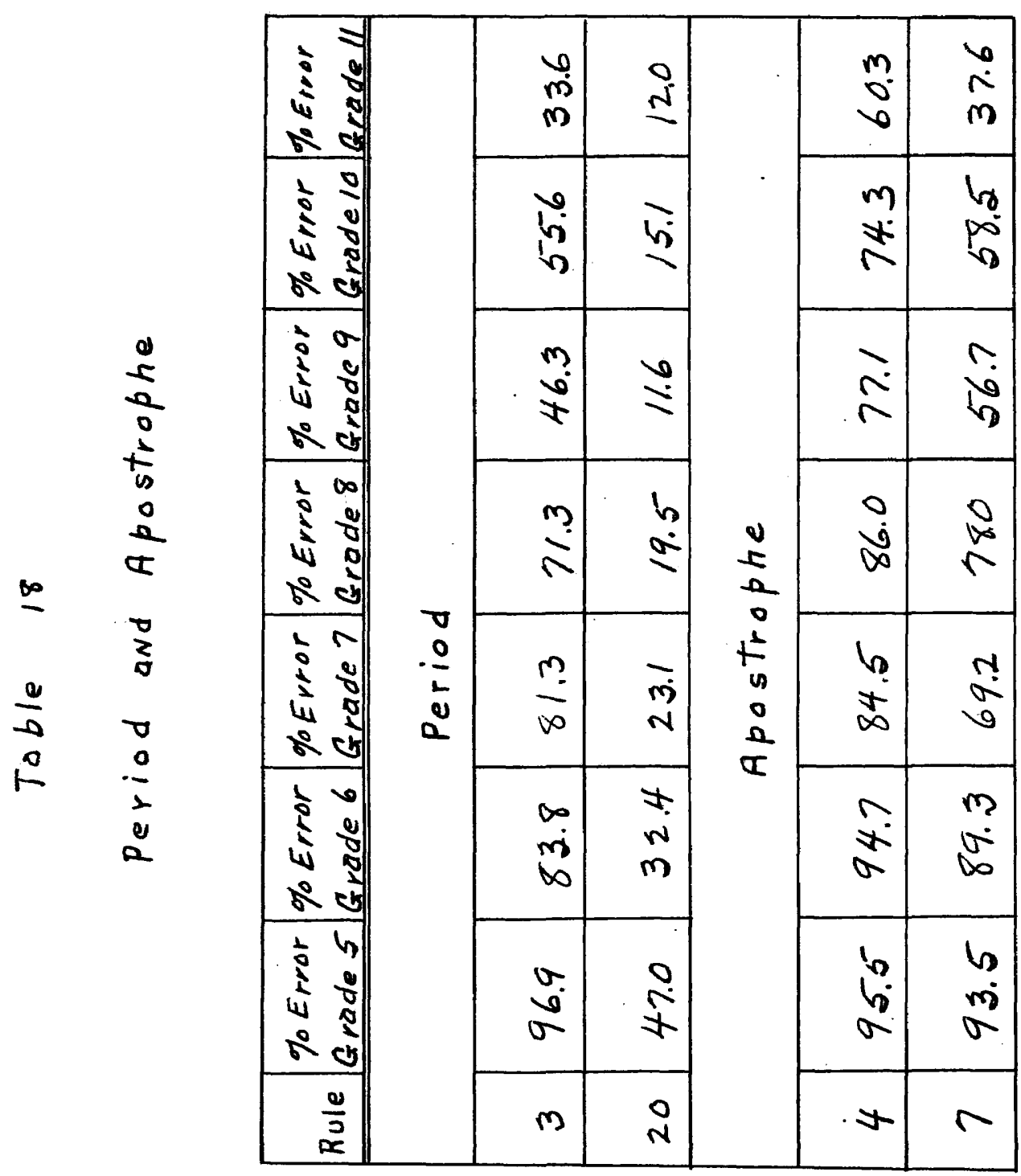




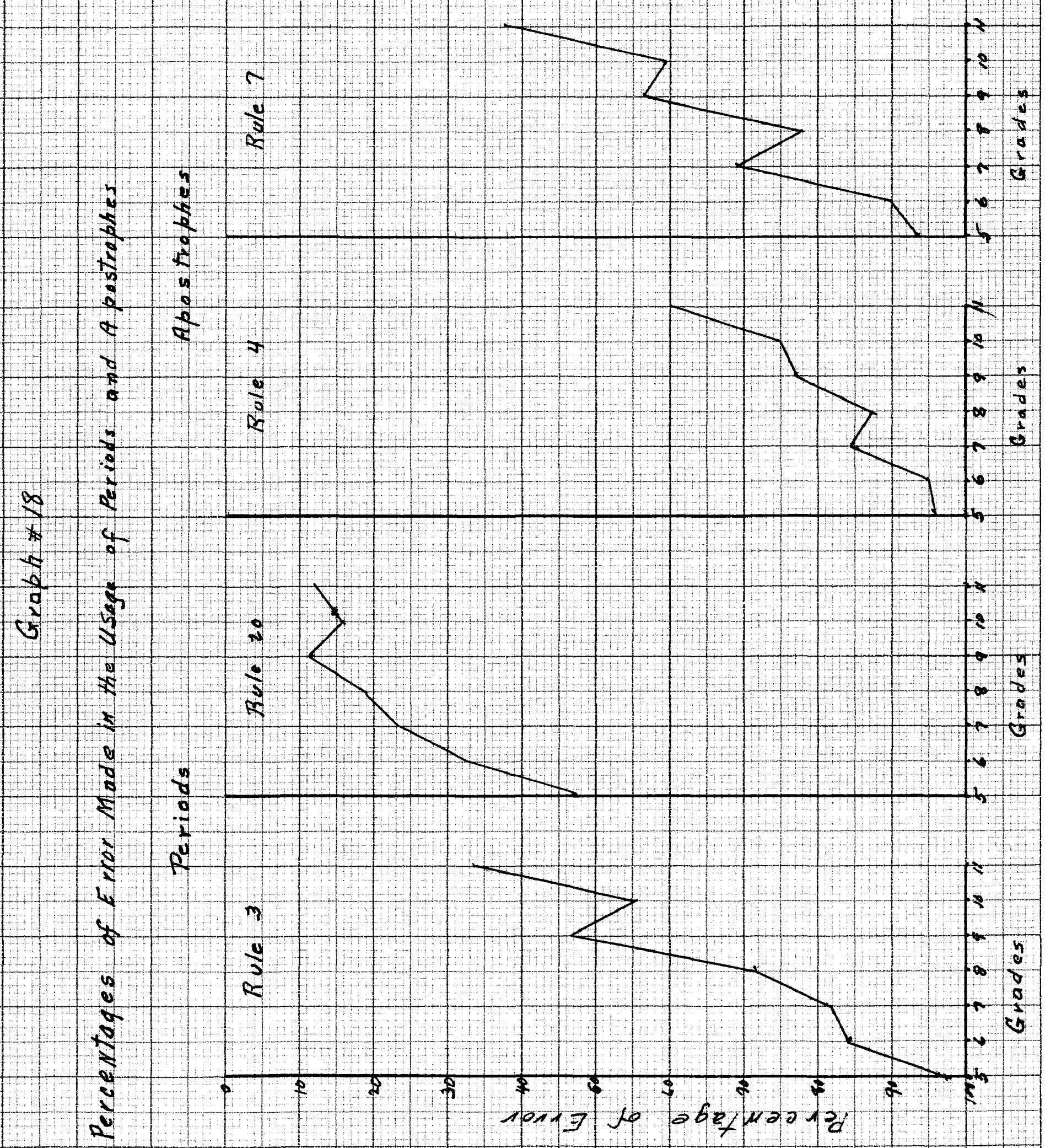




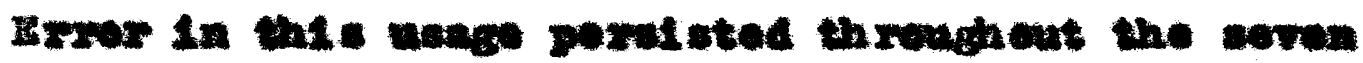

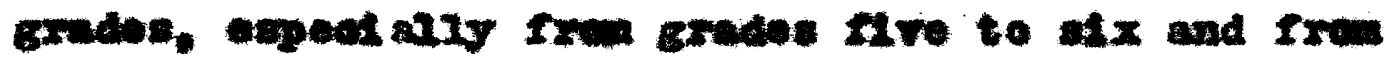
grades seven to alght. Thit is a diffieust nute and

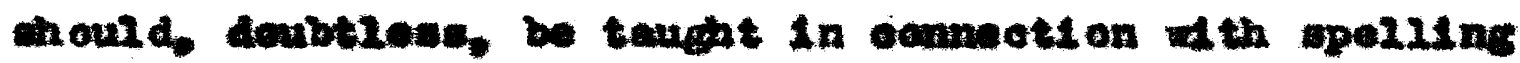

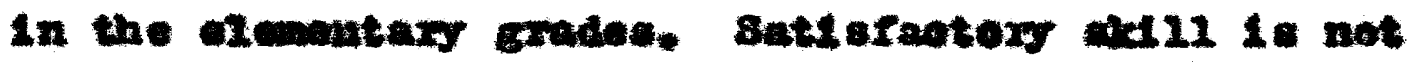
attalned oren at the end or grade erren.

Rule muber 7 - Voe an aportrughe to Indtente the ent ast on of Iotter in a centrian ton.

The crowh ourwe for this male indenten a 100 in

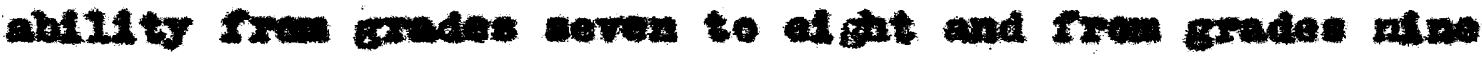

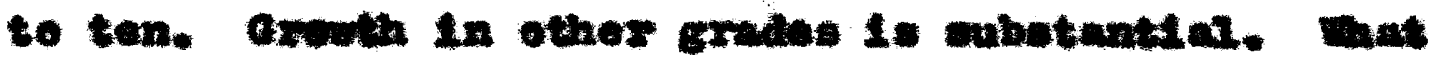

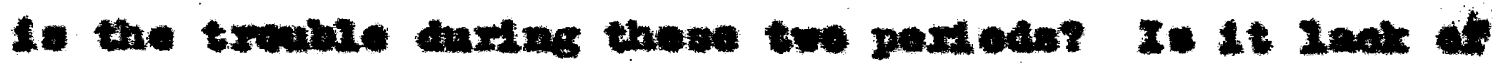
axis?

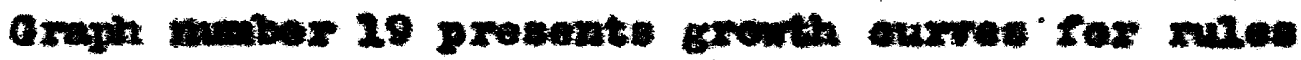

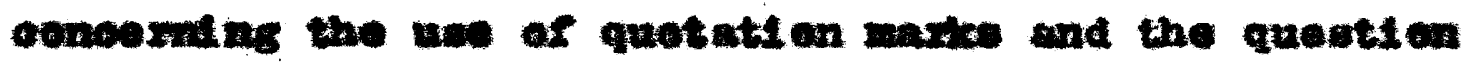
nxis.

\section{gentatien revts}

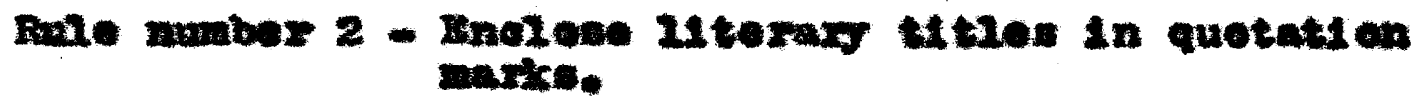

Tho rate of erowth in abilis to nee this rute

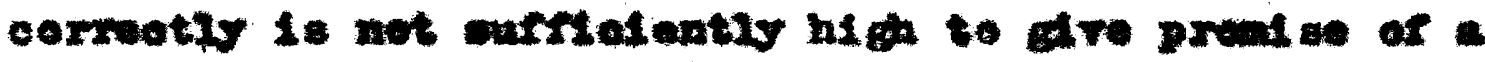
reasonablo degree of mastexy by the end of grade eleven. The achloredent ievel in grade tive it praatiealyy zore. Hoed exd ate for an Inexves in learning rate obpeotaly

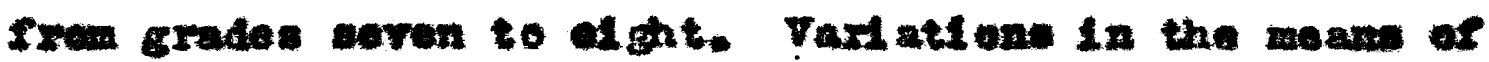

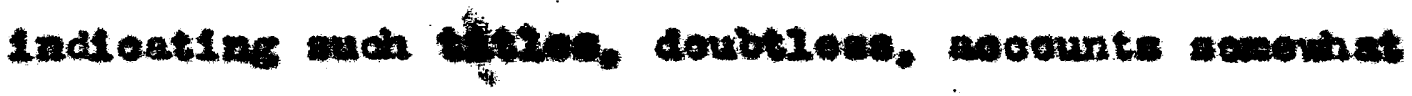




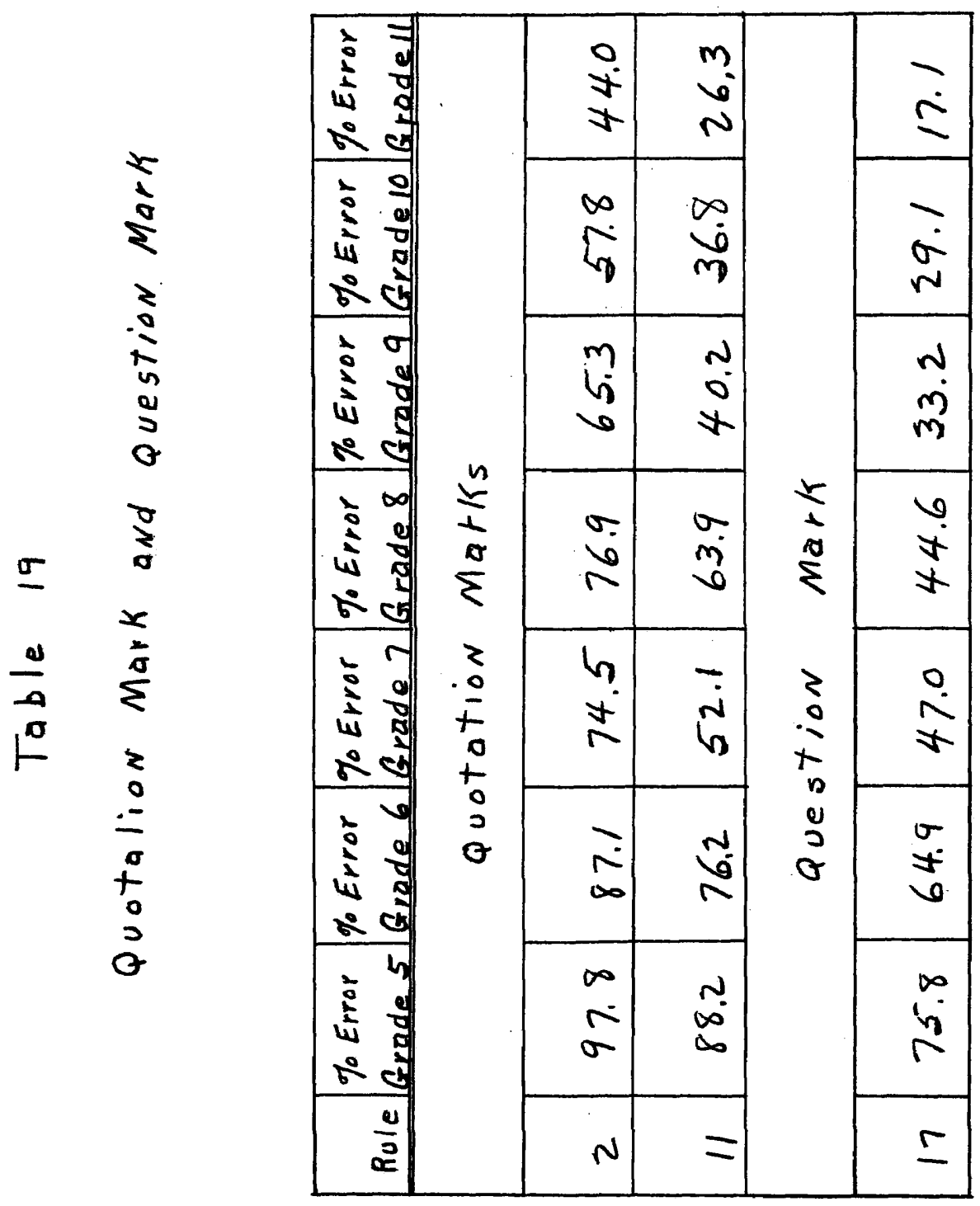




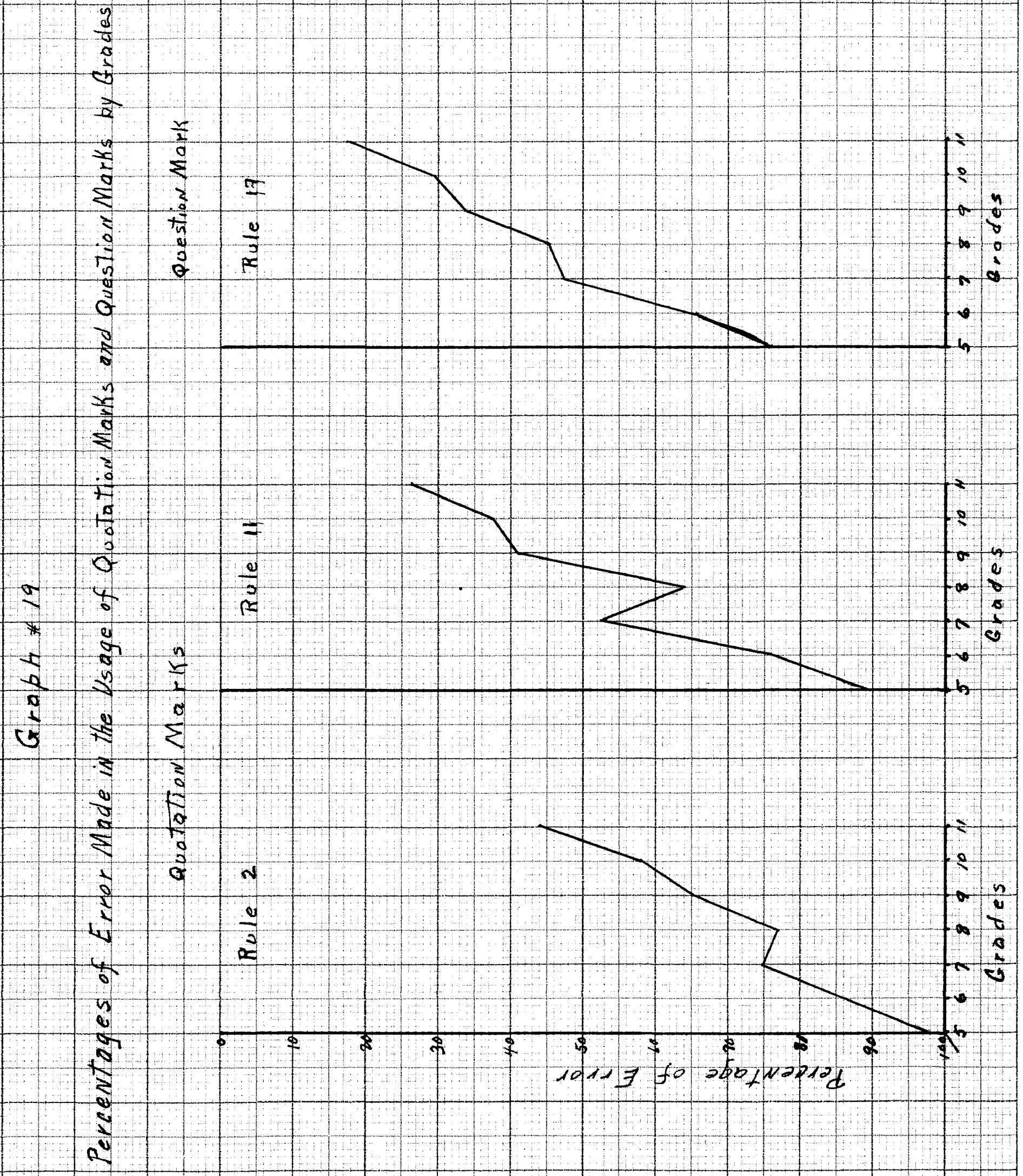


for the 2ack of mastery.

Fule muber 21 - Hy weans of quetati on maxks -eparate all di root quotations from the reat of the text matter.

The loas in ablilty to uae this mule oorrectiy from grades seven to of int 1 s the most aling aharactexistio In this ourre. What is wrone in the leaming situation during this pertod?

\section{The queation Hark}

puie number 17 - Place a queation mark at the end af ar interrogative centenoe.

Ifttle diffoulty is experleneed in learning to uae this ruie oorreotly al though the rate of learing 18 slower fron grades aeven to of ght and from grades nine to ten.

Graph number 20 predents grewth ourves for ruies concerning the use of oolons and cemioglons.

\section{The Coron}

Rule number 6 - Plase a oolon before a formal 11 at.

Error in this rule peraists throughout the

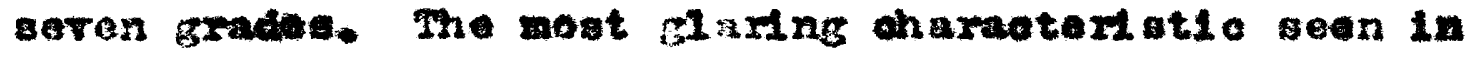
the curve for thia mis is the $10 \mathrm{sa}$ in absilty from gradea Beren to ed git.

\section{The gempoerom}

Rule nuber 9 - Use semicolon to separate Indipendent ox aunes when they are not olose2y ox lmeditely related or then they are not jolned by conjunoti ons. 


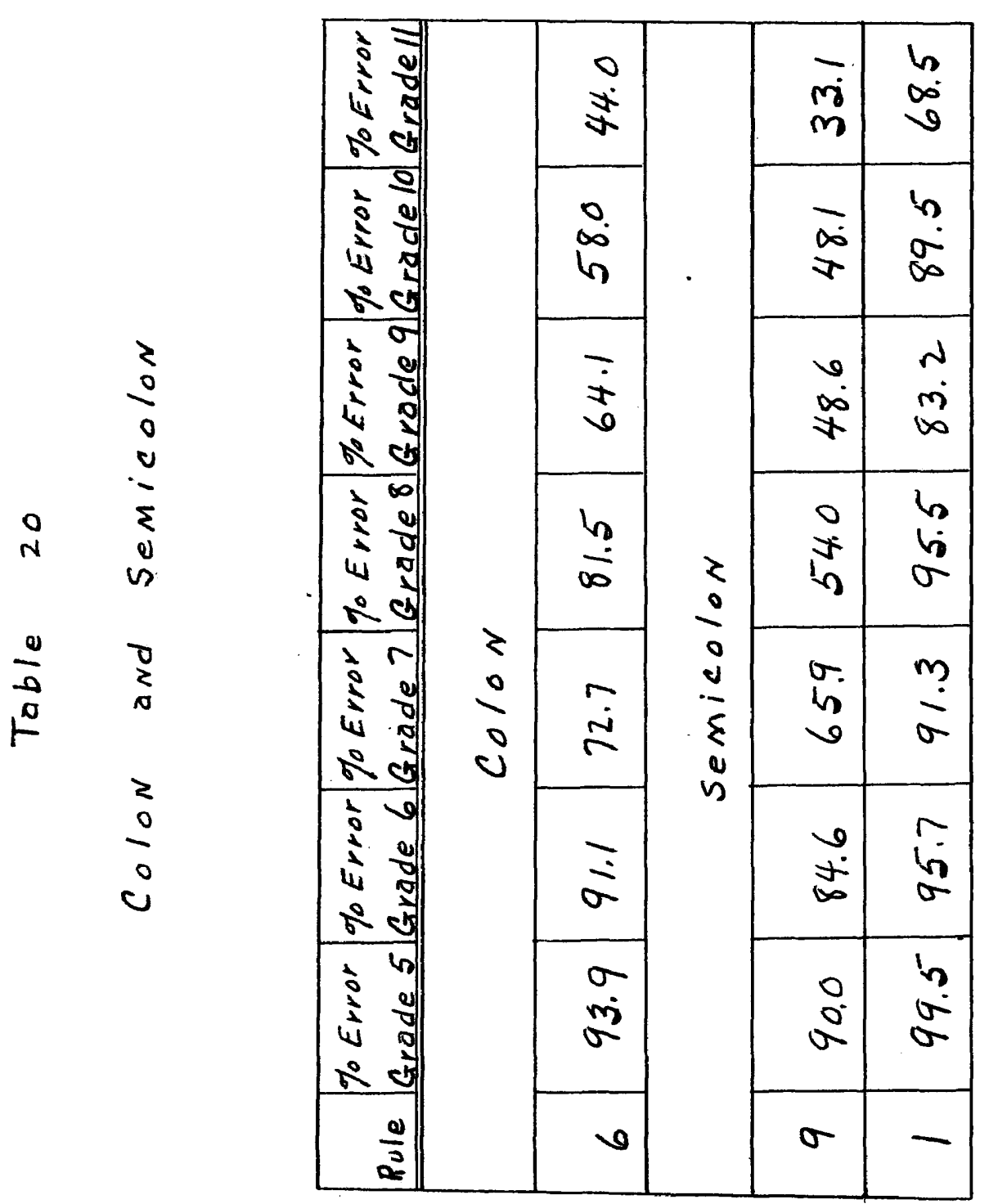




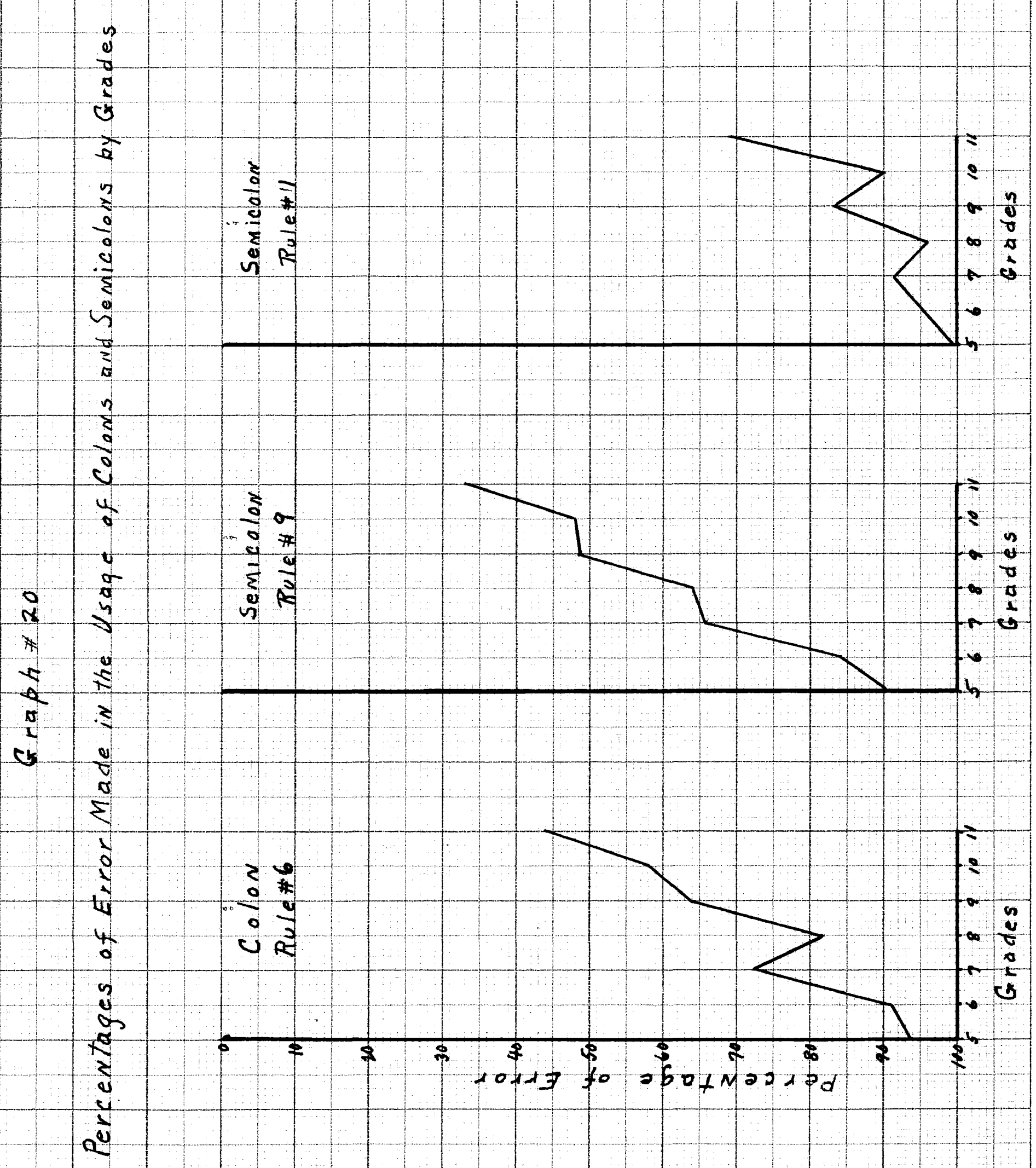


The haxp Iag in growth srem grades weren to of ghe

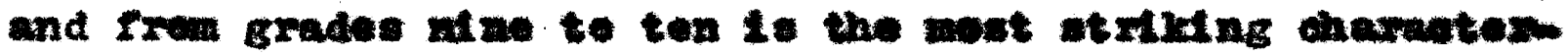

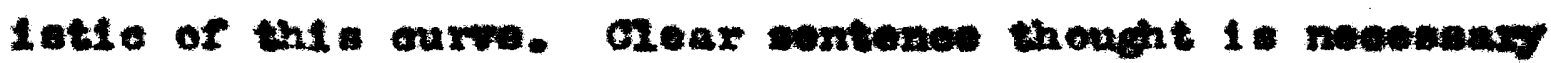
to wee this ane cortrontly.

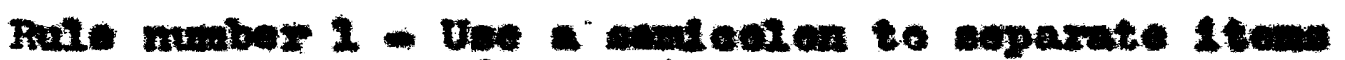

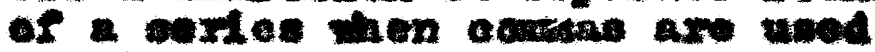
within them.

Error in this ueage $1 \mathrm{~s}$ mex peristatent than in wo

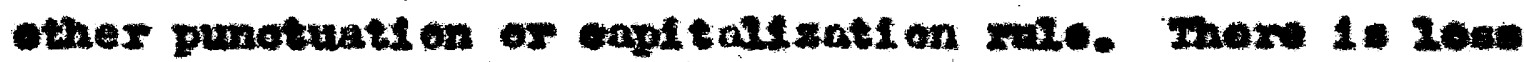
in ability fran grados peren to ofght and again from

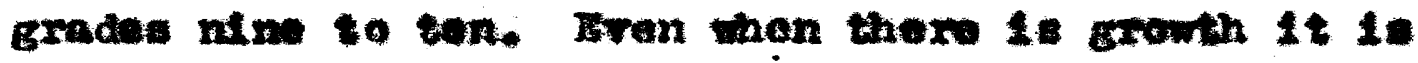

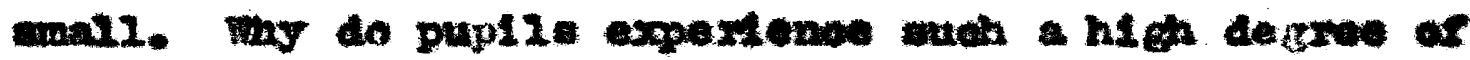

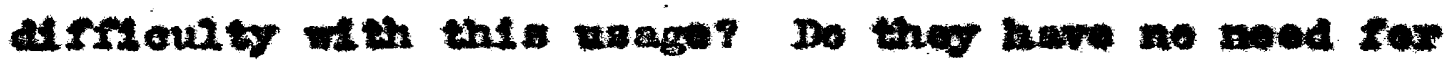

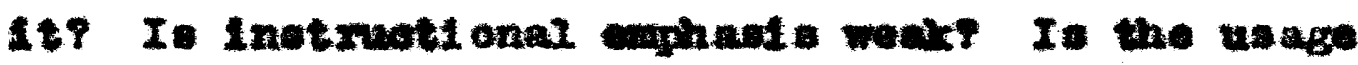

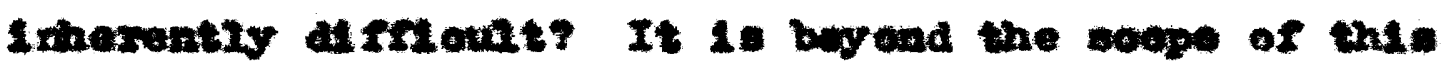
otudy to acteapt to answer these guestions.

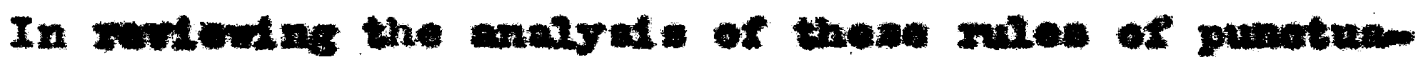
t1 on and oapttallzati on there apponrs to be semothing

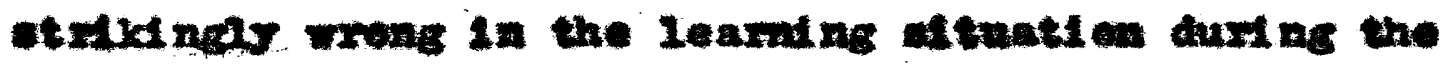

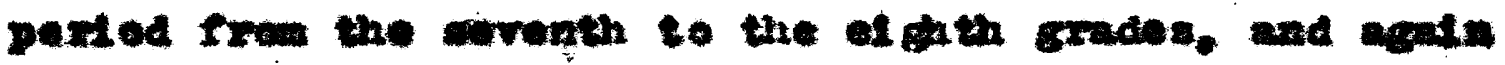
Ixw the binth to the renth graden. Fead exd at s for ruxther Invertigati on inte this at turti on. Thoed are the perteds of tranotit on Irein the clemeatary to the juntar

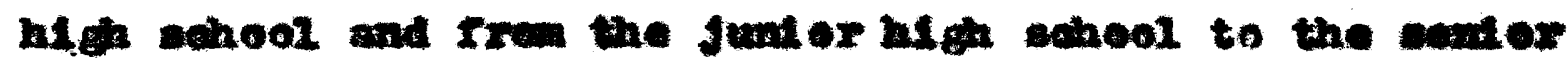

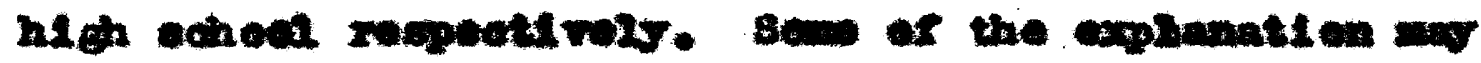


be iwherent in thin faet. Firrors consistently peral st during these two perlods. With these two exoeptions. the growth in each rule of punotuation and capl tallestion 1 s fal $2 y$ und form.

The ten "demon" mules of punctuation and capstallzation an Indoated in this study are ranked in order of peratetenoe:

\section{Eunatustion}

1. Ue semtcolon to separate 1 tems of a sextes when counas are used within them.

2. Use the apoatrophe to how the possessive of a noun.

3. Inolese 11 teraxy tities in quotation marics.

4. Place a colon before a formal 11 at.

5. Plwe a cema before "guch as" wen used in a sentence to interrupt the prinolpal thought ox wen used appoeltitraly or paronthetioally.

6. Uae an epostrophe to Indieate the cal abl on of a letter in a contraction.

7. Men a mubrcinate olause preoedes a main -1 aume. Sollow the euberdinate olause by a acrina.

\section{Cantialization}

1. Capitalise the fI rot word in each quotation.

2. Capitalize each proper adjeotive.

3. Capitallze ench proper noun.

Th1. ranking order is comared wh thankinis found In scee of the leading studses in Engli ah usapo in Table 5. 
Table E

\begin{tabular}{|c|c|c|c|c|c|c|}
\hline \multicolumn{7}{|c|}{$\begin{array}{l}\text { Comparisor of the Ranking orders INdicated } \\
\text { in other studies with the Present stody }\end{array}$} \\
\hline Role & Preseñt Study & Briggs & Leovard & Johnson & stormzand & Symoxds \\
\hline \multicolumn{7}{|c|}{ Punctuation } \\
\hline 1 & 1 & & & & & \\
\hline 4 & 2 & 1 & 2 & 1 & & 5 \\
\hline 2 & 3 & & & & & 3 \\
\hline 6 & 4 & & & & & \\
\hline 10 & 5 & & 1 & & 2 & 1.5 \\
\hline 7 & 6 & & 3 & & 1 & 1.5 \\
\hline 14 & 7 & & & & $\cdot$ & 4 \\
\hline \multicolumn{7}{|c|}{ capitalization } \\
\hline 1 & 1 & $\perp$ & & & $\perp$ & 1.5 \\
\hline 3 & 2 & 2 & & & 2 & 1.5 \\
\hline 4 & 3 & & 1 & : & & 3 \\
\hline
\end{tabular}




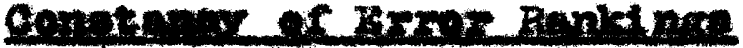

The arrers wade in eagh grade were ranked in the order of deoxvaning pexwentages mado on each zule of

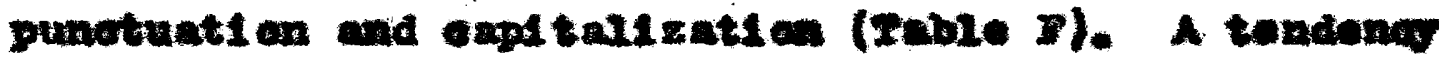

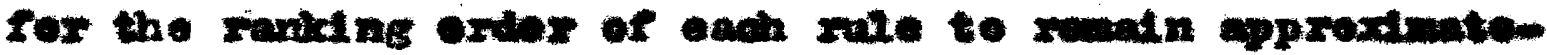
If the ene througheut the eeven grades mov bo observed. This tendeney is ebpeed aliy waxted for the elx mulen of

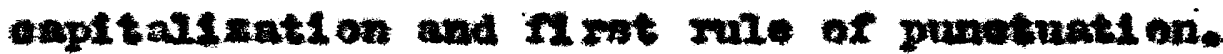

Ints pparont tendene for mes of punotuntion and expltaltantion to retain approximately the eno

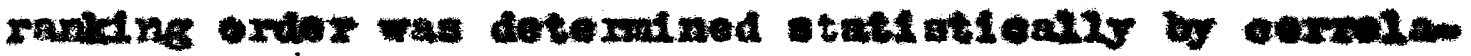
ting. ualng the wethod or raik af rroxenges, the randinge of the paruantagen of errur mads in each raie by grado Wth the randing of the woan perventage of irwex wade

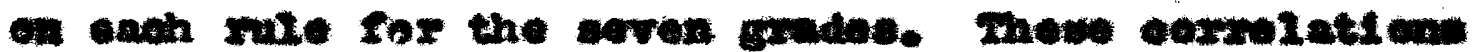

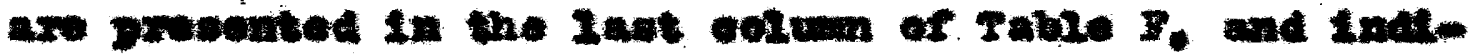

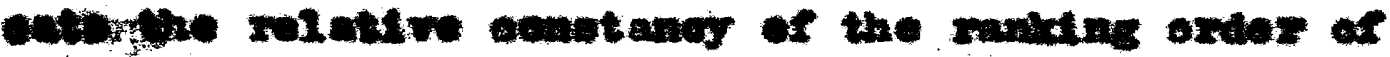
onas rus in beth punotunt on and oapt talination.

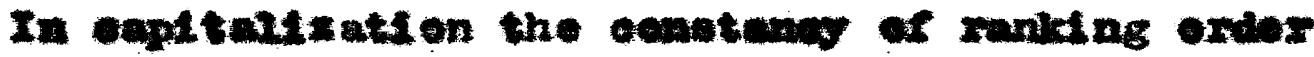
It ween to be almoet perreoty suma.

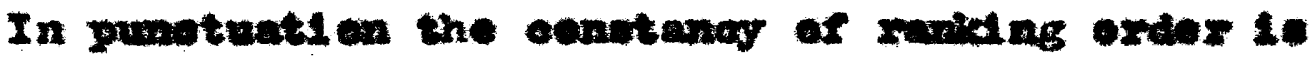

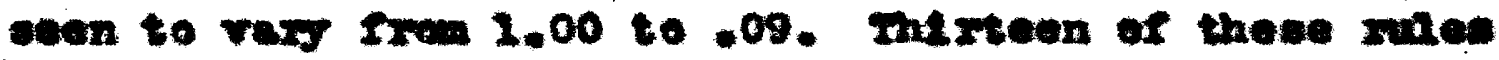

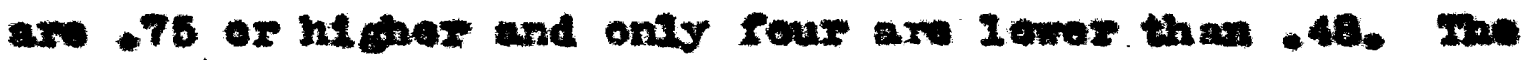
arexige deviation in ranking oribr was 1.23 and wa dotermined by ditiding the ane of the doviatione in

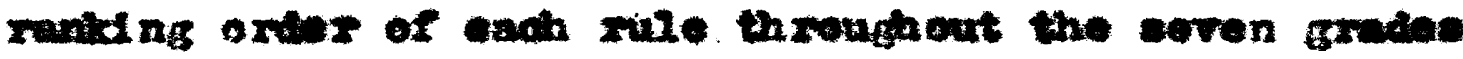


Table F

\begin{tabular}{|c|c|c|c|c|c|c|c|c|c|}
\hline \multirow{8}{*}{ 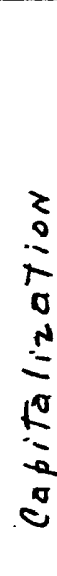 } & \multirow{2}{*}{$\begin{array}{l}\text { Rule } \\
\text { No. }\end{array}$} & \multicolumn{7}{|c|}{ Rankings of } & \multirow{2}{*}{$\begin{array}{c}\text { corre- } \\
\text { artion } \\
\text { with } \\
\text { MepN } \\
\end{array}$} \\
\hline & & Grade & Grade & Erade & arode & $\frac{b y}{\text { arode }}$ & arode & Grode & \\
\hline & 1 & 1 & 1 & 1 & 1 & 1 & 1 & 1 & 1.00 \\
\hline & 2 & 2 & 3 & 3 & 3 & 3 & 3 & 3 & .99 \\
\hline & 3 & 3 & $\varepsilon$ & 2 & 2 & 2 & 2 & 2 & .99 \\
\hline & 4 & 4 & 4 & 4 & 4 & 4 & 4 & 4 & 1.00 \\
\hline & 5 & 5 & 5 & 5 & 5 & 5 & 5 & 5 & 1.00 \\
\hline & 6 & 6 & 6 & 6 & 6 & 6 & 6 & 6 & 1.00 \\
\hline & 1 & 1 & 1 & 1 & 1 & 1 & 1 & 1 & 1.00 \\
\hline & 2 & 2 & 5 & 4 & 5 & 3 & 5 & 3.5 & .85 \\
\hline & 3 & 3 & 7 & 3 & 6 & 7.5 & 6 & 8 & .48 \\
\hline & 4 & 4 & 2 & 2 & 2 & 2 & 2 & 2 & .92 \\
\hline & 5 & 5 & 12 & 9 & 9 & 12 & 7 & 11 & .23 \\
\hline & 6 & 6 & 3 & 5 & 3 & 4 & 4 & 3.5 & .70 \\
\hline & 7 & 7 & 4 & 6 & 4 & 5 & 3 & 6 & .79 \\
\hline$z$ & 8 & 8 & 9 & 10 & 12 & 13 & 13 & 13 & .09 \\
\hline 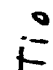 & 9 & 9 & 6 & 7 & 7 & 6 & 5 & 9 & .84 \\
\hline to & 10 & 10 & 8 & 8 & 10 & 7.5 & 7 & 5 & .67 \\
\hline$\frac{1}{0}$ & 11 & 11 & 10 & 11 & 8 & 10 & 12 & 12 & .75 \\
\hline 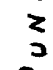 & 12 & 12 & 11 & 12 & 11 & 11 & 11 & 10 & .86 \\
\hline & 13 & 13 & 10 & 16 & 15 & 14 & 14 & 14 & 82 \\
\hline & 14 & 14 & 13 & 13 & 14 & 9 & 9 & 9 & .11 \\
\hline & 15 & 15 & 14 & 17 & 18 & 17 & 16 & 15 & 79 \\
\hline & 16 & 16 & 15 & 14 & 17 & 15 & 17 & 17 & .75 \\
\hline & 17 & 17 & 17 & 15 & 13 & 16 & 15 & 16 & .32 \\
\hline & 18 & 18 & 18 & 18 & 16 & 18 & 18 & 18 & 91 \\
\hline & 19 & 19 & 19 & 20 & 20 & 19,5 & 20 & 20 & 92 \\
\hline & 20 & 20 & 20 & 19 & 19 & 19.5 & 19 & 19 & 92 \\
\hline
\end{tabular}


(158) by seven times the number of rulea in one grade (140). Mils denonstrates that, In general, the se rulee of punotuation do not cliange in ranking order by more than 1.13 from grade to grade. These reauts indioate that error rankings in the aix ruise of onpttailzation are almost pexfootly oonstant and that the ercor rankings in the twenty rules of punotuation ahow a his degrae of oonstanoy. It $1 \mathrm{~s}$ beyzond the soope of the present atudy to deternine whether tha degree of oonstanay of an error indieates its in hexent diffloulty or the inotructional cuphas s that has been plzoed upon it or both. in investigation leading to an nocurate ranling of the difficulty expentenoed by pup118 in mastering the gramatioal usagas upon infoh punntuation and oapl tallzation usages are baved would heip to revenl the true ol gniflcance of these findinge. 
Quepter IV

\section{Bring of the Indtuge}

1. Wh the pupila usad in the atudy growth in ability to punotuate oorrotiy tands to oave from the end of the firot nemester of the adventh grace to the boglaning of the aecond amenter of the afinth grade

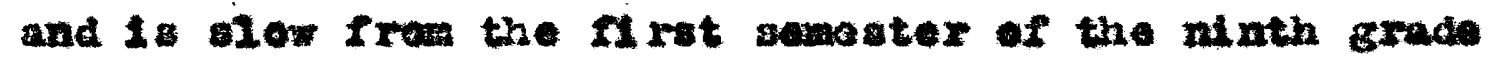
to the second semester of the tenth grade. He nead to know how goneral this oondition is and the real caure of it in these pupila.

2. Orowth in abilty to punctuate oormotiy 1 : fatry und form and abstantial from grades tive to seren. elfht te nine. and ton te elaren.

3. Orowth in abluty to oaptallas correotly tende to cobas Iron the and of the firat genester in Exade aeren to the end of the first senaster in the elenth errado.

4. Growth in ablitity to eapltallze eorreatiy is falmy und form from grados fre to acren ind from gradea elget to eleven.

5. The throe punotuation uagges in mi on matery 1 wost elonely approached by the middue of grade Leven are: (1) Perlods at the ende of dealarative ox

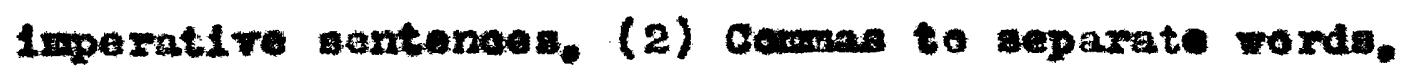
phrames, and aluses in sertob. and ( 3 ) ocmuas to 
separate names, places, and intes.

6. The envon "domen mes of punotuation in oxder of exros ares

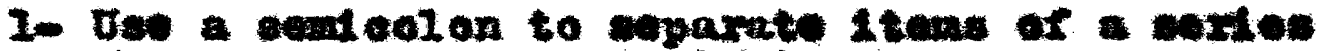

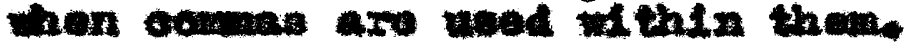

2. Uoe the apostrophe to how the peweendwe of a navin.

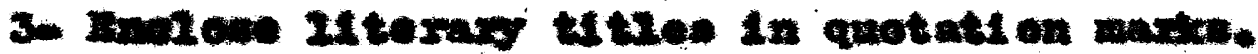

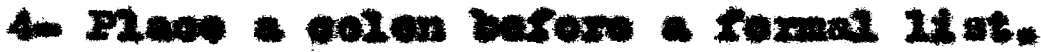

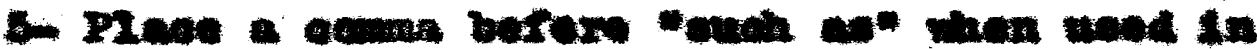

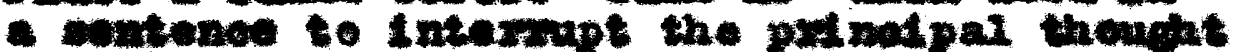

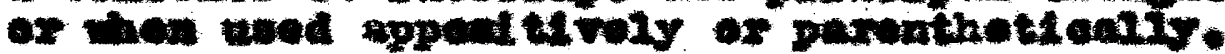

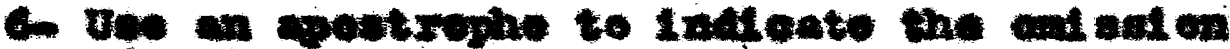
or a Ieter in a ceatradi we.

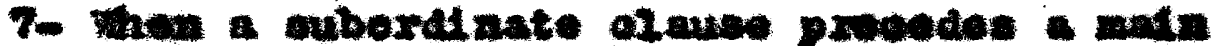

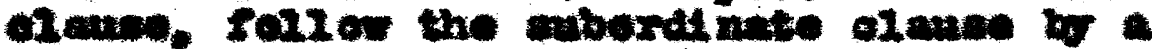
ecumas.

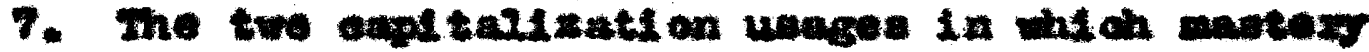

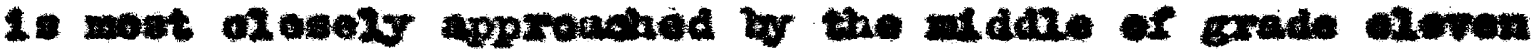

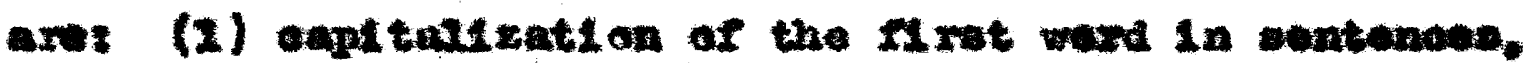
and (2) eapitaliatit on of the pronein "I*.

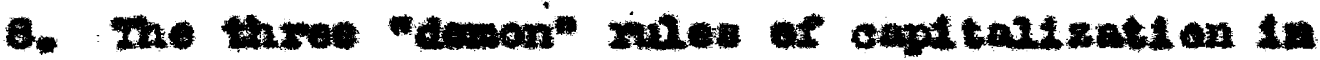
axder of axrex axe

2- Oapt tallze the etret word in each quotaktes.

2. Capt talize cech proper adjeotire.

3- Capt tals re each proper noun.

9. mex is a fairiy high degree of conotana in the error ranctins oxier of naes of punotuatien frem cander five te avon inaluatr.

10. Then is in almost porfogt oonotaney in the 
error ranking oxdor of rules of aapltallzation from grades five to eleren inoluaivo.

11. Therv 1. need for an investigation leading to sn acourate ranking of diffloulty experianeed by pup1ls on the gramatioal usages upon uilioh the rules of punctuation are based.

22. The growth in ablitty to punotuate and capttallze corroetly frem grade to grade was found to be al gnt floant in all asses expept botwhen zrades aeven and atge (Table D).

23. The decrease in the arerage peroentage of error made with all rules of punctuation and oxpltall-

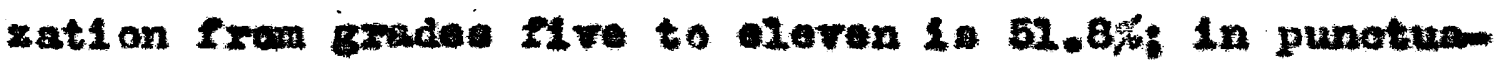
tien alone $34.4 \%$ and in eaptallation alone is $43.3 \%$ 
APPHIDTX 


\title{
LEONARD DIAGNOSTIC TEST \\ in PUNCTUATION AND CAPITAlizATION
}

\author{
By J. Paul Leonard, Ph.D. \\ Professor of Education, College of William and Mary
}

MANUAL OF DIRECTIONS

\begin{abstract}
$=$
INTRODUCTION

Purpose. For economy in teaching punctuation and capitalization and in order to meet the needs of the individual pupils in a class, the English teacher should know the ability of each pupil to punctuate correctly his compositions. The purposes of the Leonard Diagnostic Test in Punctuation and Capitalization are: (1) to diagnose the ability of pupils to recognize punctuation and capitalization errors, and $(\mathcal{Z})$ to measure progress in these phases of English. The teacher who uses the test to determine the number of errors each pupil makes on each rule will have a quick survey of the pupil's mastery of correct practices in punctuation and capitalization. This information can be supplemented by the mechanical correctness of compositions which the pupil writes. Pupils will be interested in taking the test and practicing the rules in which they made errors in the first testing.

Validity. Probably the best method of determining the mastery of correct practices in punctuation and capitalization is to get a large number of compositions from each pupil and to tabulate the errors by types. However, the teacher has no assurance that the pupil will use all the punctuation and capitalization he could doubtless utilize to advantage if he knew how to use them. Then, too, the labor in going through this procedure for a large class is so great that the average teacher neglects it. Willing ${ }^{1}$ found that comprehensive proof-reading and error-correction tests which he used were reasonably good instruments (average validity, .68) for predicting the average number of formal errors that pupils would make in 1200 words of diversified classroom-written compositions on familiar subject matter.
\end{abstract}

In 1928 the author made a study of the effect of proof-reading and correction-of-error-through-practice exercises on teaching children to punctuate their own compositions. Nearly 200,000 words of composition material written by the children were analyzed by the author to determine the growth in ability to punctuate and to capitalize as a result of eleven lessons with practice exercises. ${ }^{2}$

1 Willing, Matthew H., “Valid Diagnosis in High School Compositions," in Teachers College Contributions to Education, No. 230, pages 33-34. Bureau of Publications, Teachers College, Columbia University； 1926.

2 For a brief description of the experiment the reader is referred to Leonard, J. Paul, "The Use of Practice Exercises in Teaching Punctuation and Capitalization," Journal of Educational Research, Vol. XXI, pages 186-190; March, 1930. A more complete report of the experiment, together with a full description of the preparation of the test, will be found in Leonard, J. Paul, "The Use of

Published by World Book Company, Yonkers-on-Hudson, New York, and Chicago, Ilinois Copyright 1931 by World Book Company. Copyright in Great Britain All rights reserved. LDTPC: MD-1 
No comprehensive test in punctuation and capitalization was available for measuring achievement in the 26 rules selected for the study. The author therefore constructed one, selecting 40 possible rules based on 16 grammar and punctuation texts and several handbooks of English form. In view of the lack of agreement on the rules to be taught, opinions were obtained from three college professors and two high school teachers of English. From these judgments, 26 rules were chosen and 51 sentences prepared. The test so made was given to 800 pupils in three schools. The present test of 52 sentences is a careful revision based on the data of the preliminary form.

To determine the validity of the test, the Pearson coefficient of correlation was computed between the percentage of error made by an individual pupil on five classroom-written compositions on familiar subjects and the number of errors he made on Form A of the Leonard Diagnostic Test in Punctuation and Capitalization. Each pupil's percentage of error on his compositions was found by dividing the actual number of errors he made on his five compositions by the total number of opportunities he had for making errors. A percentage of error was then calculated for 82 children. The correlation found between these percentages and the pupils' scores on the Leonard. Diagnostic Test in Punctuation and Capitalization was .68. ${ }^{1}$

Form A of the Leonard Diagnostic Test was given to 96 pupils in January, 1928. At the same time the pupils were given the Pressey Diagnostic - Tests for Punctuation and Capitalization. The Pearson coefficient of correlation between the results the pupils made on both tests was $\mathbf{. 8 6}^{2}$

Reliability. The following are the correlations between Forms A and B :

\begin{tabular}{|c|c|c|c|c|c|c|c|c|}
\hline Grade . & . & 5 & 6 & 7 & 8 & 9 & 10 & 11 \\
\hline Correlation & $\therefore \quad$. & .873 & .911 & .961 & $.97 \mathcal{Z}$ & .979 & .954 & .876 \\
\hline Number OF $C$ & CASES & 37 & 132 & 116 & 126 & 131 & 105 & 81 \\
\hline
\end{tabular}

Nature and scope of the test. The Leonard Diagnostic Test is of a proofreading nature. The pupil is required to recognize the omission of marks of punctuation and capitalization and is asked to supply them wherever needed. Proof-reading and error-correction exercises are valuable techniques to use in teaching punctuation and capitalization. The studies referred to above show these to be reasonably satisfactory methods of arriving at pupils' probable composition errors in punctuation and capitalization. They also show that the learning does function in the pupils' own composition writing.

The test may be used to advantage from the fifth grade through the twelfth. It may be given to as many pupils as can be placed in a room. There is no time limit. The time for taking the test varies from twenty to forty minutes, depending upon the grade in which it is used.

Practice Exercises in Teaching Punctuation and Capitalization,"' Teachers College Contributions to Education, No. 372. Bureau of Publications, Teachers College, Columbia University; 1930.

1 The probable error of this coefficient was .041. The standard deviation of the test scores was 18.70, and of the percentages of error 4.19 .

2 The probable error of this coefficient was .013. The standard deviations of the scores were for the Pressey Tests 10.30 and for the Leonard Test 27.85 . 


\section{Directions for Giving the Test}

These directions should be read carefully before the test is given and should be followed closely.

1. Each pupil should be supplied with at least one sharpened pencil. (Only pencil should be used.) A supply of sharpened pencils should be at hand in case of need.

2. Say to the class: "Today we are going to see how well we can use capitalization and punctuation marks in sentences which have been partially punctuated. When you receive your copy of the test, fill in your name, age, and the other information called for on the front page. Do not open your booklet or look into it."

3. Pass out the papers. When the pupils have had time to fill in the information on the front page, say: "Pencils down. Listen carefully while I read the directions on the front page. You may read them to yourselves while I read them aloud." Read the directions.

4. Do not give any help during the test. See that there is no cheating. Supply pupils with sharpened pencils if their pencils break. Answer no questions during the course of the test.

5. There is no time limit in the sense of making the pupils hurry. However, all papers should be collected at the end of 45 minutes. A pupil who has not finished by that time can undoubtedly do no better with more time.

6. As pupils finish, urge them to look over their papers again. When a pupil is certain that he cannot improve his score, collect his paper. Have some work ready for the pupils who finish first so that such pupils will not interfere with the others who are still taking the test.

\section{Directions For Scoring}

The test is scored by an objective key supplied with each test. If the scores are to be used as measures of achievement and interpreted in terms of the norms, the key should be followed exactly. If the teacher does not care to teach a few of the rules as they are measured by the test, he may omit them from his interpretation of results and remedial teaching program. The norms are based on the entire test. However, the norms are not important for diagnostic use of the test. They indicate merely the average accomplishments of pupils on the test, and can be used to interpret achievement rather than to diagnose mastery of capitalization and punctuation.

There is some variation in accepted practice in capitalization and punctuation. The user of the test may accept, as correct, punctuation or capitalization that does not appear in the key, provided it is in accord with the instruction given by the teacher in the classroom. In that event the norms would not apply and the test would be used only for diagnostic purposes.

Each mark used correctly counts one point in the total score. For instance, in sentence No. 18 there is illustrated the rule of quotation marks 
around both parts of broken quotations. In this sentence it requires four quotation marks to complete the rule, and it is not used correctly unless all are supplied. If the pupil uses all four quotation marks correctly, he receives a score of 4 . If he misses any one, he gets one point for each one correctly used. Another example is in sentence No. 3, where principal words in titles are enclosed in quotation marks and are capitalized. There are two quotation marks and four capitals used - a total of six marks to illustrate two rules. Each complete unit, therefore, counts only as one rule, but each part of the unit counts in the total score.

Twenty-six rules of punctuation and capitalization are measured by the test. Each rule is illustrated four times. Allowing, however, for the several marks required to illustrate one rule, the total possible score is 153.

In scoring, place the key by the side of the sentences and compare the marks in the key with the ones inserted by the pupils. Capitalization and punctuation to be corrected are in boldface type in the key. Alternate acceptable, but not preferred, punctuation and capitalization are given in parentheses. When the punctuation and capitalization of the pupil's test agree with the key, make a check $(\sqrt{ })$ above the place where the mark belonged. When the pupil's marks disagree with the key, place a cross $(X)$ above the place where the mark belonged. Make a check or a cross for every mark shown on the key. When the pupil's test has been scored, add the number of each kind of scoring (checks and crosses), and place in the indicated space at the bottom of each page of the test. Then place the combined total of all of these in the spaces indicated on the first page of the test. The crosses and checks should total 153. This method provides a convenient check on the work, and the number of checks and crosses for each sentence can be compared with the number of marks required to complete each sentence. This number is given in parentheses for each sentence in the key.

If a total score is desired which can be compared with the norms, pay no attention to the marks the pupil uses which are not in the key. If only a diagnostic measure is desired, the teacher can check as incorrect each mark the pupil adds in places not indicated on the key. If this is done, there is no limit to the score.

A percentage of error can be derived for each pupil by dividing the number of errors by 153 - the total number of opportunities for making errors (provided the key is followed in scoring). The pupil's score is therefore twofold - his number of errors and his percentage of error. Percentages of error may be read directly from the table on the following page.

After the tests have been scored, the scores should be copied on to the Class Record provided with each package of tests. This record may be filed for future reference.

\section{INTERPRETATION OF SCORES}

In order to obtain the most value from the test results, the teacher should tabulate the errors made by each pupil. Such a tabulation will present the situation to the teacher in a clear and concise manner so that her reme- 
Table Showing Percentage of Error for Different Scores

\begin{tabular}{|c|c|c|c|c|c|c|c|c|c|}
\hline Score & $\begin{array}{l}\text { Per Cent } \\
\text { of Error }\end{array}$ & SCORE & $\begin{array}{l}\text { Peir Cenvt } \\
\text { of Error }\end{array}$ & Scone & $\begin{array}{l}\text { PER CENT } \\
\text { OF ERROR }\end{array}$ & SCORE & $\begin{array}{l}\text { Par Cent } \\
\text { OF ERrot }\end{array}$ & Score & $\begin{array}{l}\text { Per Cent } \\
\text { of ERror }\end{array}$ \\
\hline 1 & 1 & 32 & & 63 & 41 & 94 & 61 & 125 & 81 \\
\hline 2 . & 1 & 33 & 21 & 64 & 41 & 95 & 61 & 126 & 81 \\
\hline 3 & 2 & 34 & $2 \mathcal{2}$ & 65 & 42 & 96 & $6 \mathscr{2}$ & 127 & 82 \\
\hline 4 & 3 & 35 & 23 & 66 & 43 & 97 & 63 & 128 & 83 \\
\hline 5 & 3 & 36 & 23 & 67 & 43 & 98 & 63 & 129 & 83 \\
\hline 6 & 4 & 37 & 24 & 68 & 44 & 99 & 64 & 130 & 84 \\
\hline 7 & 5 & 38 & 25 & 69 & 45 & 100 & 65 & 131 & 85 \\
\hline 8 & 5 & 39 & 25 & 70 & 45 & 101 & 65 & 132 & 85 \\
\hline 9 & 6 & 40 & $\mathcal{2} 6$ & 71 & 46 & 102 & 66 & 133 & 86 \\
\hline 10 & 6 & 41 & 26 & 72 & 46 & 103 & 66 & 134 & 86 \\
\hline 11 & 7 & 42 & 27 & 73 & 47 & 104 & 67 & 135 & 87 \\
\hline 12 & 8 & 43 & 28 & 74 & 48 & 105 & 68 & 136 & 88 \\
\hline 13 & 8 & 44 & 28 & 75 & 48 & 106 & 68 & 137 & 88 . \\
\hline 14 & 9 & 45 & 29 & 76 & 49 & 107 & 69 & 138 & 89 \\
\hline 15 & 10 & 46 & 30 & 77 & 50 & 108 & 70 & 139 & 90 \\
\hline 16 & 10 & 47 & 30 & 78 & 50 & 109 & 70 & 140 & 91 \\
\hline 17 & 11 & 48 & 31 & 79 & 51 & 110 & 71 & 141 & 91 \\
\hline 18 & 12 & 49 & 32 & 80 & $5 \mathfrak{2}$ & 111 & $\boldsymbol{\gamma \mathcal { Q }}$ & 142 & $\mathbf{9} 2$ \\
\hline 19 & 12 & 50 & 32 & 81 & $5 \mathcal{Q}$ & 112 & $7 \mathcal{2}$ & 143 & $\mathbf{9 2}$ \\
\hline 20 & 13 & 51 & 33 & $8 \mathcal{2}$ & 53 & 113 & 73 & 144 & 93 \\
\hline $\mathcal{2 1}$ & 13 & $5 \mathcal{2}$ & 34 & 83 & 54 & 114 & 74 & 145 & 94 \\
\hline 22 & 14 & 53 & 34 & 84 & 54 & 115 & 74 & 146 & 94 \\
\hline 23 & 15 & 54 & 35 & 85 & 55 & 116 & 75 & 147 & 95 \\
\hline $\mathcal{2 4}$ & 15 & 55 & 35 & 86 & 56 & 117 & 76 & 148 & 96 \\
\hline 25 & 16 & 56 & 36 & 87 & 56 & 118 & 76 & 149 & 96 \\
\hline 26 & 17 & 57 & 37 & 88 & 57 & 119 & 77 & 150 & 97 \\
\hline 27 & 17 & 58 & 37 & 89 & 57 & 120 & 77 & 151 & 97 \\
\hline 28 & 18 & 59 & 38 & 90 & 58 & 121 & 78 & 152 & 98 \\
\hline 29 & 19 & 60 & 39 & 91 & 59 & 122 & 79 & 153 & 99 \\
\hline 30 & 19 & 61 & 39 & $9 \mathcal{2}$ & 59 & 123 & 79 & 154 & 99 \\
\hline 31 & 20 & 62 & 40 & 93 & 60 & 124 & 80 & 155 & 100 \\
\hline
\end{tabular}

dial instruction will be as effective as possible. The rules covered by the test are given below.

In the test several rules are oftentimes illustrated in each sentence. This provides more of a normal punctuation situation for the pupil. The teacher is interested in knowing what rules are violated by the pupil and where remedial instruction needs to be applied.

The following list shows the sentences that cover each rule and the number of times (given in parentheses) that the rule is covered in the particular sentence :

RULE

\section{Capitalization}

1. Capitalize each proper noun.

2. Capitalize each proper adjective.

2 (1),

2 (1),

5 (1),

6 (1),

18 (1)

$3(4)$,

4. Capitalize the first word in each quotation.

5. Capitalize the pronoun $\mathbf{I}$.

6. Capitalize the principal words in titles.
SENTENCE IN WHICH

RULE IS ILLUSTRATED

15 (1), 21 (1),

$33(1), 37$ (1),

51 (1)

$8(1), 13(1)$,

51 (1)

11 (1), 23 (1),

15 (1)

22 (1), 30 (1),

46 (1)

$12(\mathcal{2}), \quad 19(\mathcal{2})$,

$50(1)$

\section{Punctuation}

7. Place a period at the end of a declarative or an imperative sentence.

$8(1), \quad 15(1), \quad 21(1), \quad 22(1)$

8. Place a period after each abbreviation and initial.

$14(1), \quad 28(4), \quad 37(1), \quad 48(1)$

(Continued on next page) 


\section{Leonard Diagnostic Test in Punctuation and Capitalization}

\section{Apostrophe}

RULE

9. Use an apostrophe to show the possessive of a noun.

10. Use an apostrophe to indicate the omission of a letter in a contraction.

\section{Quotation Marks}

11. By means of quotation marks separate all direct quotations from the rest of the text matter.

12. Enclose literary titles in quotation marks.

\section{Colon}

13. Place a colon before a formal list.

\section{Semicolon}

14. Use a semicolon to separate independent clauses when they are not closely or immediately related or when they are not joined by conjunctions.

15. Use a semicolon to separate items of a series when commas are used within them.

\section{Question Mark}

16. Place a question mark at the end of an interrogative sentence.

\section{Comma}

17. Use commas to separate words, phrases, and clauses in a series; and put a comma before "and" when it is used to join the last two items of the series.

18. Separate appositives by commas. (Dashes may sometimes be used if the appositive is strictly explanatory.)

19. Separate a parenthetical expression from the text matter by commas or dashes.

20. Place a comma before "such as" when used in a sentence to interrupt the principal thought or when used appositively or parenthetically.

21. By means of commas separate all direct quotations from the rest of the text matter.

22. Set off by commas the name of a person addressed.

23. Use the comma to set off the name of a state from the name of a place in the state, a street from a city, the year from the day of the month, a place from a date, or a name from a place.

24. Commas are usually used to separate independent clauses that are joined by such coördinating conjunctions as but, for, because, if, nor, as, or and.

25. When a subordinate clause precedes a main clause, follow the subordinate clause by a comma.

26. Set off non-restrictive clauses and phrases by commas.
SENTENCE IN WHICH

RULÈ IS ILLUSTRATED

$9(1), \quad 18(1), \quad 31(1), \quad 47(1)$

$6(2), \quad 11(\mathcal{Q}), \quad 18(4), \quad 21$ (4)

$3(\mathcal{2}), \quad 12(\mathcal{2}), \quad 19(\mathcal{2}), \quad 32(\mathcal{2})$

$1(1), \quad 13(1), \quad 24(1)$,

$35(1)$

\section{7}

$2(\mathcal{2}), \quad 9,(\mathcal{Q}), \quad 15(\mathcal{2})$

8 (1), 30 (1),

41 (1),

$44(1)$

18 (1),

21 (1),

33 (2),

$43(2)$

7 (1),

25 (1)

34 (2),

48 (1)

$4(2)$

$10(2)$

14 (3)

$20(4)$

33 (1)

43 (1)

47 (1)

$50(1)$

16 (1)

22 (1),

27 (1).

36 (1)

17 (1)

33 (1),

$38(2)$ 
The following list shows the rules illustrated in the various sentences:

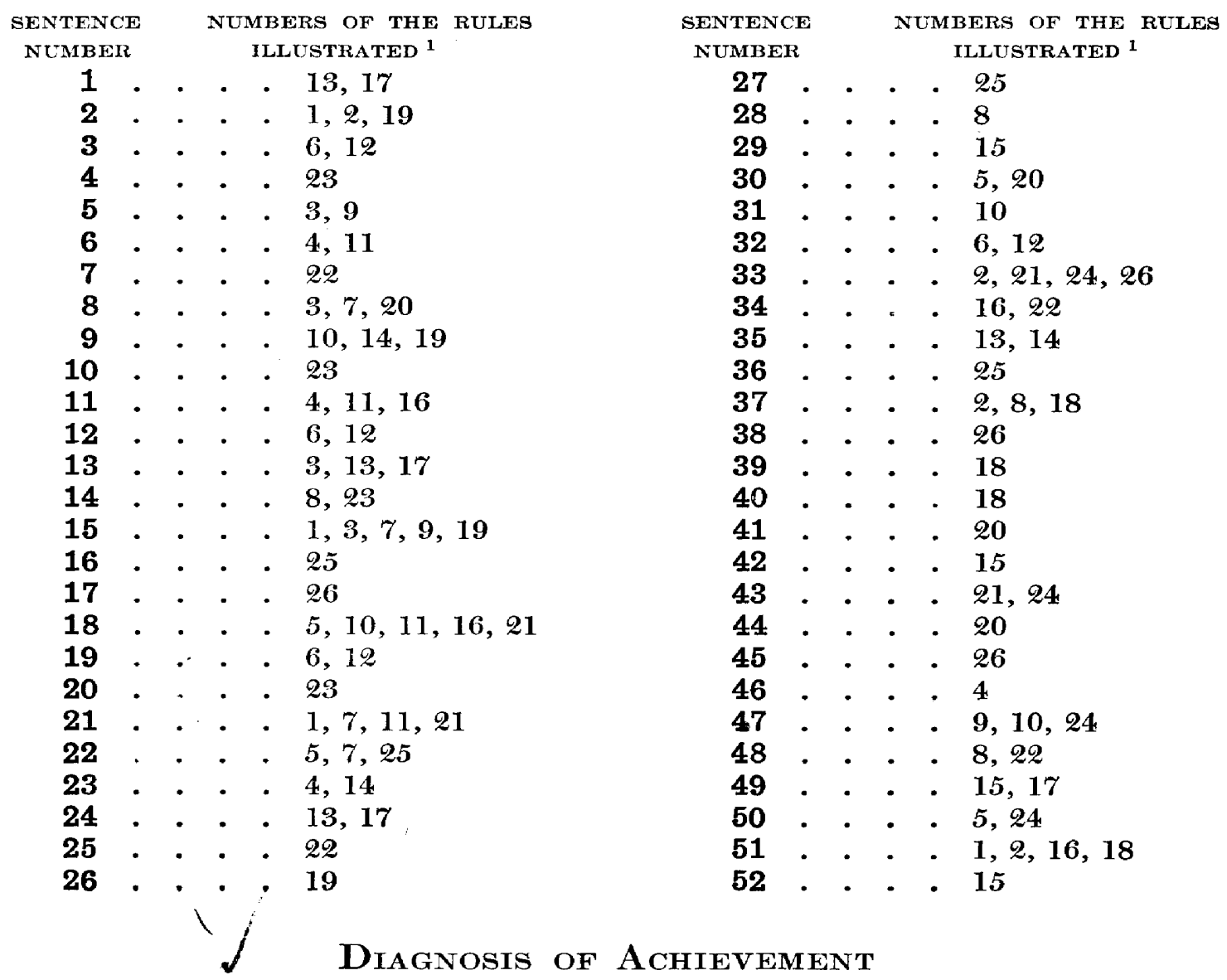

For the maximum use of the test the teacher should fill out the Diagnostic Chart. Doing this is a mechanical process and can be accomplished without a knowledge of the test or the placement of rules in the test. The chart is arranged so that a clerk can fill it out by exercising reasonable care, but it can be done best by having two people work on it - one to read from the pupil's test, the other to tabulate errors read.

Note that space is provided on the chart for each mark of punctuation and capitalization used in the test in the exact order of its occurrence. In most of the columns only one mark is represented, but in a few cases irom two to four marks may be represented. These numbers are indicated on the chart in the row headed "Number of Errors." This is the only heading that needs to receive attention while the chart is being filled out.

To fill out the chart when two people are working together, proceed as follows : ${ }^{2}$

1. In scoring, all errors on the test were indicated by crosses and all correct marks by checks. In filling out the chart only crosses are entered. However, both crosses and checks should be called by the reader in order to enable the tabulator to do his work most easily. Every time a cross is read, it is to be entered on the chart; every time a check is read, a space is to be skipped equivalent to one punctuation or capitalization mark used.

I These are the numbers of the rules as given above (pages 5-6).

${ }^{2}$ If only one person fills out the chart, follow the same procedure suggested for two people, except that the same person reads and tabulates. 
2. Arrange all the test papers in the class in alphabetical order; then number them in order - $1,2,3$, etc.

3. The reader then takes the test of pupil No. 1 and calls off from the test "Cross" or "Check" in the order of appearance on the pupil's test.

4. As the reader calls, the tabulator moves across the chart horizontally from box to box with each "Cross" or "Check" called by the reader, except that when the column heading for "Number of Errors" is more than one, the person tabulating must enter the same number of crosses (or skip for checks) as the number at the top of the column. By comparing the number of sentences tabulated with the number read from time to time, a convenient check-up on the accuracy of the work can be made.

After the Diagnostic Chart is completed the teacher should transfer this information to the Class Record, which shows the total number of errors made by each pupil with each rule and gives the total possible errors for each rule. To fill out the Class Record, proceed as follows :

1. On the Diagnostic Chart consider the first 26 numbers on the left-hand side, which were used to represent the numbers of the individual pupils, to represent also the numbers of the rules.

2. The four asterisks in row No. 1 show the columns in which the errors in rule 1 were tabulated. The four asterisks in row No. 2 show the columns in which the errors in rule 2 were tabulated, etc. By means of this device the number of errors made in each rule by each pupil can be determined. These numbers should be recorded on the Class Record.

3. When that form is completely filled out, the columns and rows should be totaled to show at the bottom the total number of errors made by each pupil on all the rules, and at the right the total number of errors made in each rule by all the pupils.

The teacher is now ready to plan her remedial program on the basis of individual needs as shown by the Diagnostic Chart and the Class Record. The teacher may safely assume that no class time need be taken to drill children on a rule which is used incorrectly only 25 per cent of the time as measured by the test. These errors may be given special attention in the written work of the individual pupil, if necessary. However, pupils who show percentages of errors above 25 per cent, as measured by the test, should be given special drill in the punctuation or capitalization marks. If the rule or its application is new to the pupils or most of them make errors in the same rule, then its usage may be taught to the entire class. If only a few need practice in the application of the rule, individual self-teaching practice exercises on the rule in which the pupil shows deficiencies should be given. This enables the teacher to teach pupils individually and at the same time make certain that they will know a given amount of punctuation and capitalization in the end. ${ }^{1}$

In treating the test scores as measures of achievement the teacher may compare the class average, as well as individual scores of pupils, with the norms. A more fruitful interpretation of the scores can be obtained by

\footnotetext{
1 Suggestions for definite teaching in such a manner, together with experimental evidence of its value, may be found in the author's dissertation on "Practice Exercises in Teaching Punctuation and Capitalization," Teachers College Contributions to Education, No. 372. Teachers College, Columbia University ; 1930.
} 
changing them to percentile ranks. For this purpose the Universal Percentile Graph ${ }^{1}$ can be used conveniently. With the form for the graph are given instructions for its construction and interpretation.

\section{Norms}

Norms are of value chiefly as a basis for comparison of individual scores or class averages with the average achievement as determined from various school systems. Norms are of little value in diagnosing pupils' mastery of the rules of capitalization and punctuation.

For diagnostic purposes the teacher should determine what the pupil has achieved in terms of what it was possible for him to do-his percentage of error - or in terms of what he was supposed to have learned. To measure progress, the achievement at the eñd af a given period on one form of the test should be compared with achievement at the beginning of that period on the other form of the test.

The following table is based on almost 5000 cases in Grades 5 to 12 inclusive, drawn from schools in areas varying from typically rural to large cities. The smallest number of cases for any one grade is over 200. Both forms of the test were given in November to almost all the pupils. Norms for tenths of a grade are interpolated between the scores for November. Norms below Grade $5^{3}$ and above $12^{3}$ are extrapolated values. The table applies to both Forms $A$ and $B$.

\begin{tabular}{|c|c|c|c|c|c|}
\hline GRADE & SCORE & Grade & SCORE & $G_{\mathrm{RADE}}$ & SCORE \\
\hline $12^{10}$ & 131 & $9^{10}$ & 104 & $6^{10}$ & 61 \\
\hline $12^{9}$ & 130 & $9^{9}$ & 103 & $6^{9}$ & 60 \\
\hline $12^{8}$ & 130 & $9^{8}$ & 102 & $6^{8}$ & 58 \\
\hline $12^{7}$ & 129 & $9^{7}$ & 100 & $6^{7}$ & 56 \\
\hline $12^{6}$ & 128 & $9^{6}$ & 99 & $6^{6}$ & 55 \\
\hline $12^{5}$ & 128 & $9^{5}$ & 97 & $6^{5}$ & 53 \\
\hline $12^{4}$ & 127 & $\mathbf{9}^{4}$ & 96 & $6^{4}$ & 52 \\
\hline $12^{3}$ & 126 & $9^{3}$ & 95 & $6^{3}$ & 50 \\
\hline $12^{2}$ & 125 & $\mathbf{9}^{2}$ & 94 & $6^{2}$ & 48 \\
\hline $12^{1}$ & 124 & $9^{1}$ & 92 & $6^{1}$ & 47 \\
\hline $11^{10}$ & 124 & $8^{10}$ & 91 & $5^{10}$ & 45 \\
\hline $11^{9}$ & 123 & $8^{9}$ & 89 & $5^{9}$ & 44 \\
\hline $11^{8}$ & 122 & $8^{8}$ & 88 & $5^{8}$ & 41 \\
\hline $11^{7}$ & 121 & $8^{7}$ & 86 & $5^{7}$ & 40 \\
\hline $11^{6}$ & 120 & $8^{6}$ & 85 & $5^{6}$ & 39 \\
\hline $11^{5}$ & 120 & $8^{5}$ & 83 & $5^{5}$ & 37 \\
\hline $11^{4}$ & 119 & $8^{4}$ & 82 & $5^{4}$ & 36 \\
\hline $11^{3}$ & 118 & $8^{3}$ & 80 & $5^{3}$ & 34 \\
\hline $11^{2}$ & 117 & $8^{2}$ & 79 & $5^{2}$ & 33 \\
\hline $11^{1}$ & 116 & $8^{1}$ & 77 & $5^{1}$ & 31 \\
\hline $10^{10}$ & 115 & $7^{10}$ & 76 & $4^{10}$ & 30 \\
\hline $10^{9}$ & 114 & $7^{9}$ & 74 & $4^{9}$ & 28 \\
\hline $10^{8}$ & 113 & $7^{8}$ & 73 & $4^{8}$ & 27 \\
\hline $10^{7}$ & 112 & $7^{7}$ & 72 & $4^{7}$ & 26 \\
\hline $10^{6}$ & 111 & $7^{6}$ & 70 & $4^{6}$ & 24 \\
\hline $10^{5}$ & 110 & $7^{5}$ & 69 & $\mathbf{4}^{5}$ & 23 \\
\hline $10^{4}$ & 109 & $7^{4}$ & 67 & $\mathbf{4}^{4}$ & 21 \\
\hline $10^{3}$ & 108 & $7^{3}$ & 66 & $4^{3}$ & 20 \\
\hline $10^{2}$ & 107 & $7^{2}$ & 64 & $4^{2}$ & 19 \\
\hline $10^{1}$ & 105 & $7^{1}$ & 63 & $4^{1}$ & 17 \\
\hline
\end{tabular}

1 By A. S. Otis. Published by World Book Company, Yonkers-on-Hudson, New York. 
The table is read as follows: A pupil who obtains a score of 131 points does as well on the test as the average pupil finishing Grade 12. A pupil whose score on the test is $\mathbf{8 3}$ does as well on the test as the average pupil in the middle of Grade 8.

It is often desirable to express a pupil's achievement in terms of his grade. This may be done by expressing his score as a percentile rank; that is, the percentage of pupils of his grade whose scores are exceeded by his score. Thus, if a pupil's score is higher than the scores of 62 per cent of the pupils of his grade, we say that his grade percentile is 62. This very meaningful method of interpreting test scores can be done in terms of the school distribution of scores by the procedure explained in the Universal Percentile Graph. ${ }^{1}$

The following table gives percentile ranks for November based on the scores for almost 5000 pupils from different parts of the country. For values obtained at other times of the year than November, it is necessary to interpolate between the grade columns in this table. The table is read as follows: A fifth-grade pupil obtaining a score of 57 points on the test in November has a grade percentile rank of 80 . A pupil in the sixth grade whose score on the test in November is 54 has a percentile rank of 57 ; etc.

The table applies to both Forms $A$ and $B$.

\begin{tabular}{|c|c|c|c|c|c|c|c|c|}
\hline \multirow{2}{*}{$\begin{array}{l}\text { PerCentTLE } \\
\text { RANK }\end{array}$} & \multicolumn{8}{|c|}{ GRADE } \\
\hline & 5 & 6 & 7 & 8 & 9 & 10 & 11 & 12 \\
\hline 98 & 90 & 101 & 114 & 128 & 134 & 142 & 144 & 144 \\
\hline 95 & 77 & 91 & 105 & 119 & 127 & 136 & 139 & 142 \\
\hline 90 & 68 & 83 & 97 & 112 & 121 & 131 & 136 & 139 \\
\hline 85 & 62 & 77 & 91 & 106 & 116 & 127 & 133 & 137 \\
\hline 80 & 57 & 72 & 86 & 102 & 112 & 123 & 130 & 135 \\
\hline 75 & 52 & 67 & $8 \mathscr{Z}$ & 97 & 109 & 120 & 128 & 134 \\
\hline 70 & 48 & 63 & 78 & 93 & 107 & 118 & 126 & 132 \\
\hline 65 & 44 & 59 & 74 & 90 & 104 & 116 & 124 & 131 \\
\hline 60 & 40 & 56 & 71 & 86 & 101 & 114 & 122 & 129 \\
\hline 55 & 37 & 53 & 68 & 83 & 98 & 112 & 120 & 128 \\
\hline 50 & 34 & 50 & 66 & 80 & 95 & 108 & 118 & 126 \\
\hline 4.5 & 31 & 47 & 63 & 77 & 92 & 105 & 115 & 124 \\
\hline 40 & 28 & 45 & 60 & 73 & 88 & 102 & 112 & 121 \\
\hline 35 & 26 & 43 & 57 & 68 & 83 & 98 & 108 & 117 \\
\hline 30 & 23 & 39 & 53 & 64 & 79 & 94 & 105 & 113 \\
\hline 25 & 21 & 36 & 49 & 60 & 75 & 90 & 100 & 109 \\
\hline 20 & 18 & 32 & 46 & 55 & 70 & 85 & 95 & 104 \\
\hline 15 & 14 & 28 & 41 & 50 & 64 & 78 & 89 & 98 \\
\hline 10 & 11 & $\mathscr{2 2}$ & 34 & 44 & 57 & 72 & 82 & 90 \\
\hline 5 & 7 & 16 & 25 & 36 & 47 & 60 & 70 & 80 \\
\hline $\boldsymbol{z}$ & 3 & 10 & 17 & 27 & 37 & 48 & 60 & 68 \\
\hline
\end{tabular}

1 World Book Company. 


\title{
LEONARD DIAGNOSTIC TEST \\ IN PUNCTUATION AND CAPITALIZATION
}

\author{
By J. Paul Leonard, Ph.D. \\ Professor of Education, College of William and Mary
}

TEST: FORM A

Do not open this booklet, or turn it over until you are told to do so. Fill these blanks, giving your name, age, etc. Write plainly.

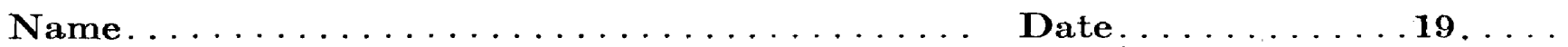

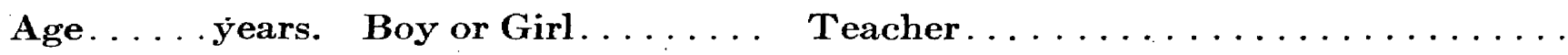

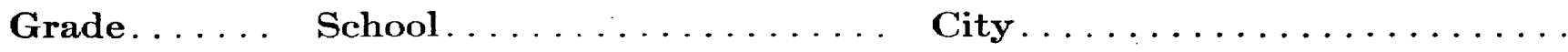

General Directions. Here are several sentences printed without some necessary commas, capital letters, apostrophes, periods, question marks, quotation marks, colons, and semicolons.

Read each sentence very carefully; then insert the necessary punctuation and capitalization where you think they belong.

Do not change any punctuation or capitalization used in the following exercises. Each mark used is correct; you are merely to supply those that have been omitted. Each sentence is complete; there are no part sentences, and no sentences are run together. Read the entire sentence first to get its meaning.

Do not hurry. You will be given plenty of time to complete the test. When you have finished the test, look over your paper; then sit quietly until you are asked to give your paper to the teacher.

Ask no questions after the test has begun.

Total number of errors $(\times) \ldots \ldots \ldots$

$\frac{\text { Total number correct }(\sqrt{ }) \ldots \ldots \ldots}{\text { Total should be }}$

Percentage of errors $($ Number of errors $\div 153) \ldots \ldots$

Published by World Book Company, Yonkers-on-Hụdson, New York, and Chicago, Illinois Copyright 1930 by World Book Company. Copyright in Great Britain All rights reserved. LDTPC: $\mathrm{A}^{-1}$ 
1. You may proceed as follows hold the flask fill it with acid boil it gently and note its change in color.

2. Thomas hardy-a great english novelist died in 1928.

3. Charles Dickens wrote a tale of two cities.

4. New York City January 26 1930, appeared at the top of the letter.

5. the flower fell on the soldiers grave.

6. He jumped to his feet and cried, we will not stand for this outrage!

7. Charles you have done excellent work.

8. my brother does many queer things such as giving money to every beggar he meets.

9. Peter the cat we had in the country knew the supper hour he was never late for supper, and he didnt have a wrist watch either.

10. My address this summer will be 37 Laclede Avenue Cleveland Ohio.

11. The senator asked, when shall we declare war

12. I am writing a paper called Children's love of poetry.

13. the following five girls belong to the basketball team Mary Louise Frances Ellena and Elizabeth.

14. The dentist's appointment card read: Mrs George Davis 27 Orange Avenue February 181930.

15. another voice answered; and then the first voice which was silvers took up the. story

16. Away went the children laughing in glee.

17. He left the woods and walked along the Albany Post Road where he could make better progress.

18. Fellows said Wilson, dont you know what $I$ would do if $i$ owned half of that dog

19. You will probably be interested in seeing Mr. Barrie's fantasy called peter pan.

(Go right on to page 3.) 
20. On September 101930 Mary Ryan's address was 9 East Batson Street Los Angeles California.

21. Captain kidd said charles, was the best pirate that ever lived

22. Although $I$ am afraid yet $i$ am no coward

23. A famous man once said, "make the best of everything think the best of everybody."

24. Bring the following things to class pen pencil and paper.

25. "Mr. Jones I'm sorry, but it is necessary to trade you to another team," said the manager.

26. Rayon silk which is made by a chemical process is being widely used instead of real silk spun by silkworms.

27. There came to my house a stranger fleeing from justice.

28. Columbia University confers the $\mathbf{A} B$ and $\mathbf{A} \mathbf{M}$ degrees.

29. The articles that indicate rank, membership, and attendance in our club are for sale only to members that is to say, our pin, our badge, and our ring may not be bought by anyone outside of the club.

30. My schedule includes many studies that $i$ like such as art, music, and dancing.

31. It isnt true that $I$ am the best friend your brother has.

32. Louis Untermeyer has compiled a book of poetry called this singing world, which you would probably be interested in reading.

33. "Mayor Jones" said the speaker "who is an authority on french Literature has made many friends in this community because he has been willing to talk frequently on the subject."

34. What would happen Father if $I$ should miss the train

35. Read the following directions think before you write punctuate as you write never use a punctuation mark unless you are sure of its correct use.

36. Although they agreed to leave early Bill was not ready on time.

37. Mr Smith our principal was formerly a spanish teacher.

(Go right on to page 4.) 
38. The foreigner who was the cook at our summer camp came from the tenement section on the East Side.

39. The Democratic Convention of 1928 met in Houston a city in Texas.

40. The Grand Canyon which is one of the National Parks is visited each year by thousands of tourists.

41. Many relics such as fire flints, warming pans, and muskets are preserved in museums.

42. Nicknames are often used for boys' names, such as, for Theodore, Ted for James, Jim.

43. "George" said the coach "you will not need to report for basketball practice this afternoon for $I$ want you to rest for the game tonight."

44. It is difficult to become accustomed to the new modern furniture such as that which is made perfectly square and is raised only a few inches from the floor.

45. Most great men those who have been the leaders of society have been men of vision and ideals.

46. He turned to his friend and said, "you have been a fine pal to me."

47. Im more interested in golf than in Browns club for on the golf course one can discuss mens business. affairs.

48. Dr Smith will you please report on your visit to the Orient?

49. If I were a sailor I would have relics from China Japan Turkey and India and all my friends would know of my wanderings, my collections, and my various experiences.

50. I must return to school this afternoon but before $i$ go $I$ must see my doctor.

51. Who said that becky our persian cat was killed yesterday

52. Our organization is for the promotion of social life, good humor, and repartee it is in no sense a club for study, politics, or business. 


\section{LEONARD DIAGNOSTIC TEST \\ IN PUNCTUATION AND CAPITALIZATION}

\section{KEY : FORM A}

\section{Directions}

If the scores are to be evaluated in terms of the norms, only the punctuation given in the key should be allowed. Otherwise the teacher may also allow as correct any punctuation, other than that given in the key, that has been taught to the class. For more complete directions for scoring see the Manual of Directions (pages 3 and 4).

Where more than one method of punctuation and capitalization may be followed, the less preferred forms are given in parentheses. For ease in scoring, all capitalization and punctuation are indicated in boldface type.

The key indicates for each sentence only the places where there should be punctuation or capitalization. Thus, in the first sentence the key should be read as follows: The pupil should place a colon after "follows," a comma after "flask," a comma after "acid," and a comma after "gently."

When the same word occurs twice in a sentence and is also used in the key, the word which precedes the one in the key is given in parentheses in the key in order to avoid confusion. See sentence 15, " (first) voice."

Each mark (both punctuation and capitalization) used correctly is given 1 point credit. For instance, in sentence 1 the maximum score is 4 points, 1 for the semicolon and 1 for each comma. In sentence 18 there is illustrated the rule for quotation marks around both parts of broken quotations. In this sentence it requires four quotation marks to complete the rule. One point is given for each of the four quotation marks that is put in the proper place. The maximum number of points for each sentence is given in parentheses after the correct punctuation for the sentence.

Place the key beside the sentences and compare the marks in the key with those inserted by the pupil. When the pupil's test agrees with the key, place a check $(\checkmark)$ above the mark. When the pupil's mark disagrees with the key, or when the pupil has omitted a mark, place a cross $(x)$ above it. At the foot of each page indicate the number of right and wrong marks, on the lines provided. (For this purpose count omitted items as wrong.)

Disregard all punctuation added by the pupil that is not indicated in the key, even though it is incorrect. (See Manual of Directions, page 4.)

Published by World Book Company

Yonkers-on-Hudson, New York, and Chicago, Illinois Copyright 1930 by World Book Company Copyright in Great Britain

All rights reserved

PRINTED IN U.S.A
Leonard Diagnostic Test : A : Key

(Page 2)

1. follows: (or - ) flask, acid, gently, (4) (or follows: (or -) flask; acid; gently;) (hold may be capitalized)

2. Hardy, English novelist,

3. "A Tale of Two Cities"

4. City, 26,

5. The soldier's

6. "We outrage"

7. Charles,

8. My things, meets.

9. Peter, country, hour;
didn't

10. Avenue, Cleveland,

11. "When war?"

12. "Children's Love Poetry"

13. The team: (or -) Mary, Louise, Frances, Ellena,

14. Mrs. Davis, Avenue, 18,

15. Another (first) voice, Silver's, story.

16. children,

17. Road,

18. "Fellows," "don't I dog?"

19. "Peter Pan" 
20. 10, 1930, $\begin{aligned} & \text { (Page 3) } \\ & \text { Street, Angeles, (4) }\end{aligned}$

20. 10, 1930, $\begin{aligned} & \text { (Page 3) } \\ & \text { Street, Angeles, (4) }\end{aligned}$

21. "Captain Kidd," "was lived." ( 7 )

22. afraid, I coward.

23. Make everything;

24. class: (or -) pen, pencil,

(3)

25. Jones,

26. silk, process,

27. house,

28. A.B. A.M.

29. members;

44. furniture,

20. 10, 1930, $\begin{aligned} & \text { (Page 3) } \\ & \text { Street, Angeles, (4) }\end{aligned}$

20. 10, 1930, $\begin{aligned} & \text { (Page 3) } \\ & \text { Street, Angeles, (4) }\end{aligned}$

39. Houston,

( 1

40. Canyon, Parks,

41. relics,

( 1

42. Ted;

43. George, coach, afternoon,

( 3 )

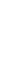

30. I like,

31. isn't

32. "This Singing World"

45. men, (or -$)$ society, (or -$)$ ( $:$

46. You

47. I'm Brown's club, men's (4)

48. Dr. Smith,

33. Jones, speaker, French Literature, community,

34. happen, Father, 'train?

35. directions: (or -) write; write; (3) (or directions: (or - ) write, write, ) (think may be capitalized)

36. early,

37. Mr. Smith, principal, Spanish
49. China, Japan, Turkey, India; (4)

50. afternoon, I

51. Becky, Persian cat, yesterday? ( 5 ) 52. repartee; 
LEONARD DIAGNOSTIC TEST

\section{IN PUNCTUATION AND CAPITALIZATION}

DIAGNOSTIC CHART

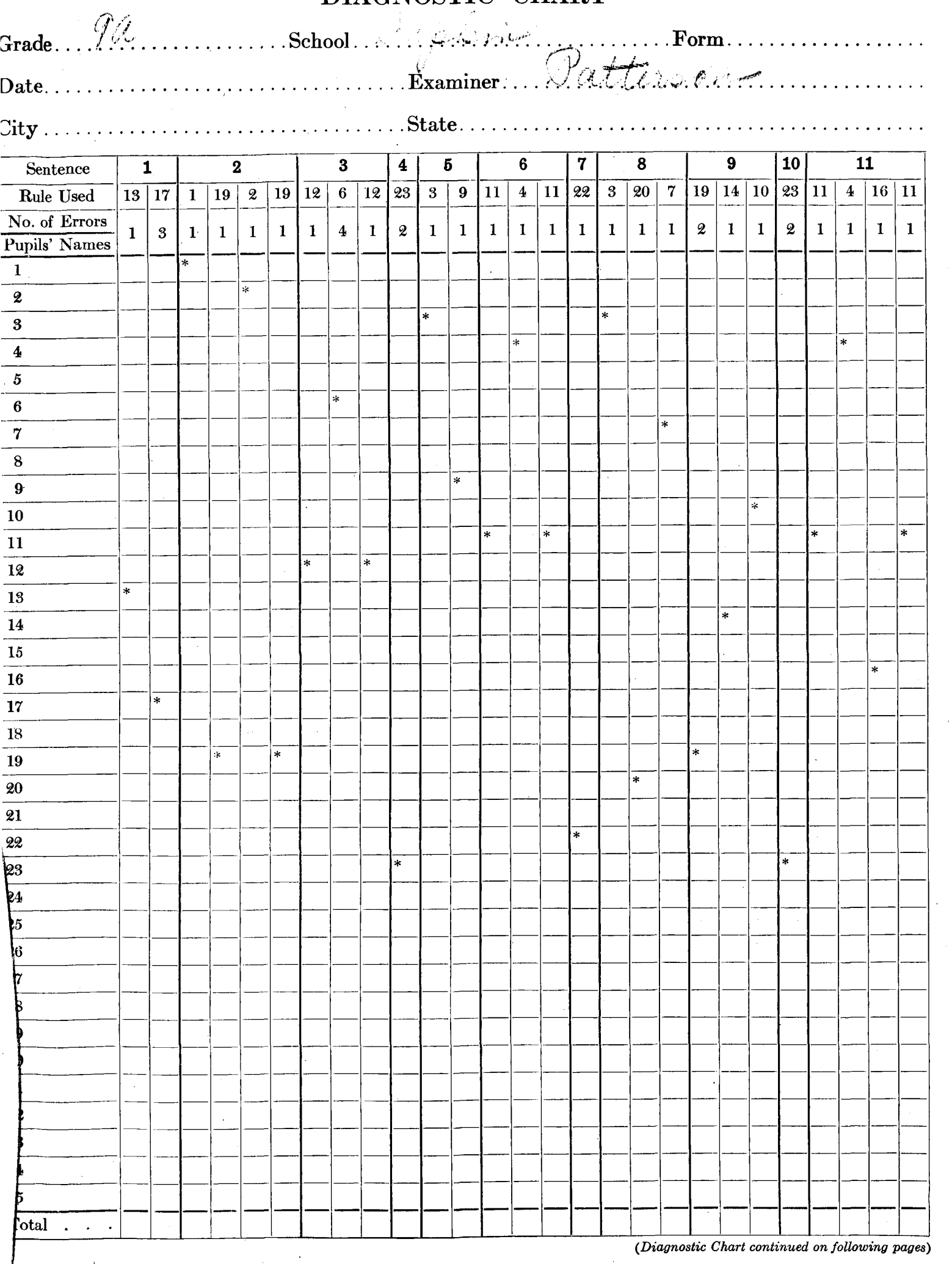

\section{DIAGNOSTIC CHART - Continued}

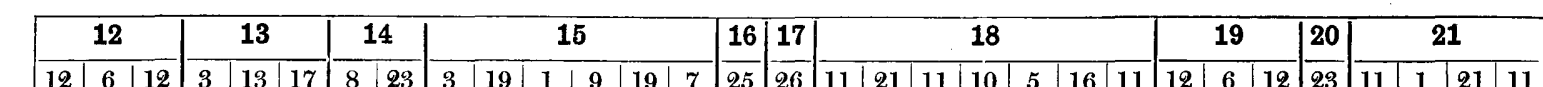

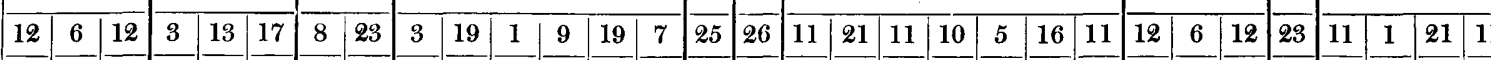

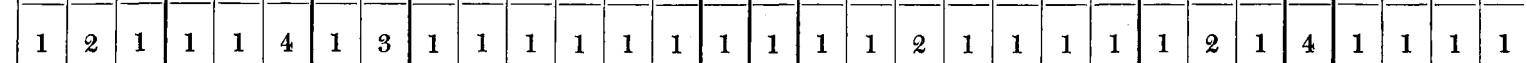

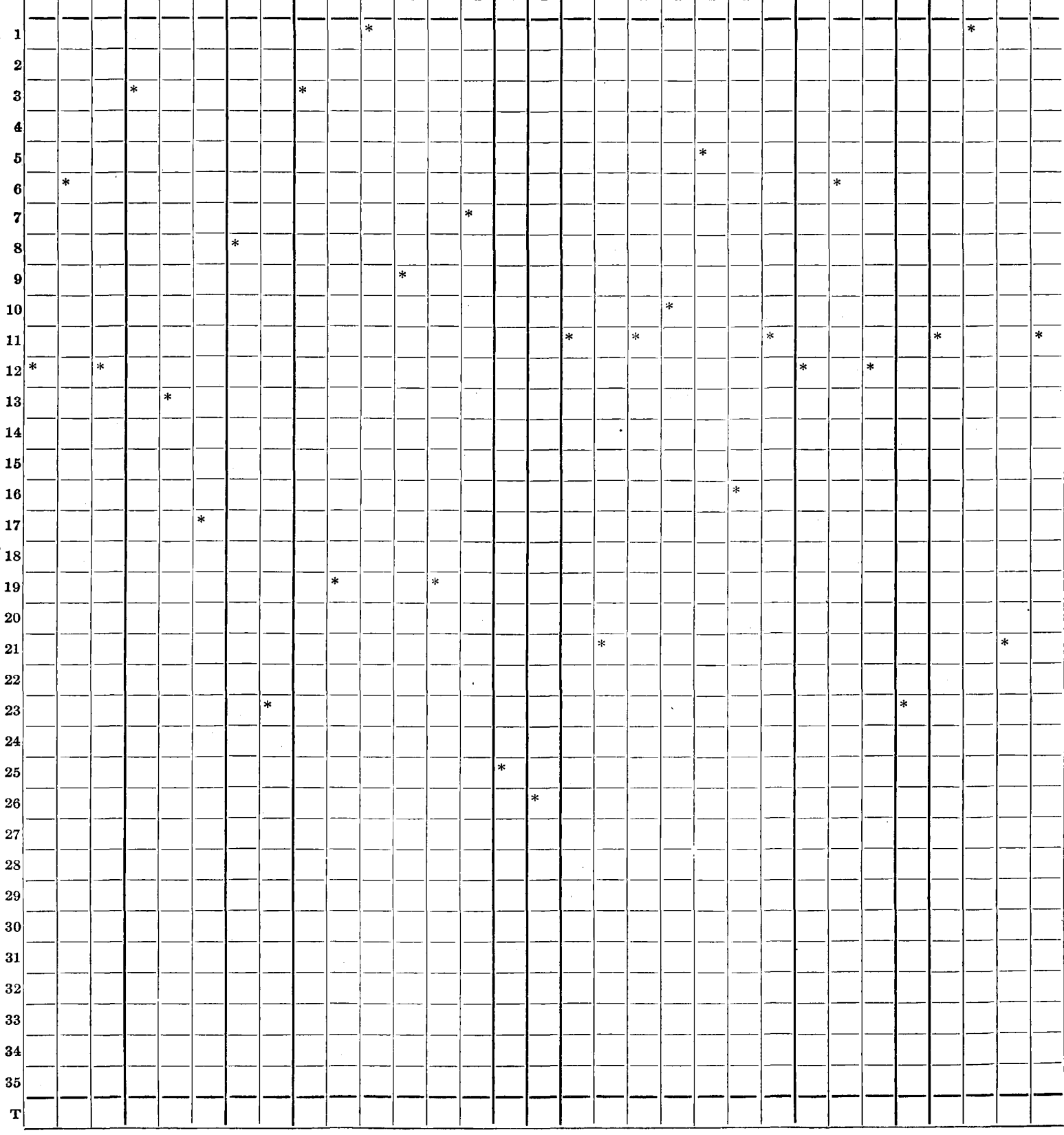
[ 2] 
DIAGNOSTIC CHART - Continued

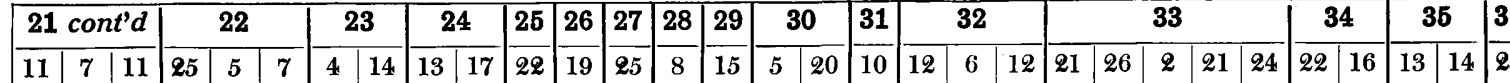
\begin{tabular}{lllllllllllllllllllllllllllllllllllll}
\hline 1 & 1 & 1 & 1 & 1 & 1 & 1 & 1 & 1 & 2 & 1 & 2 & 1 & 4 & 1 & 1 & 1 & 1 & 1 & 3 & 1 & 1 & 1 & 1 & 1 & 1 & 2 & 1 & 1 & 2 & 1
\end{tabular} (*) [3.]
DIAGNOSTIC CHART - Continued

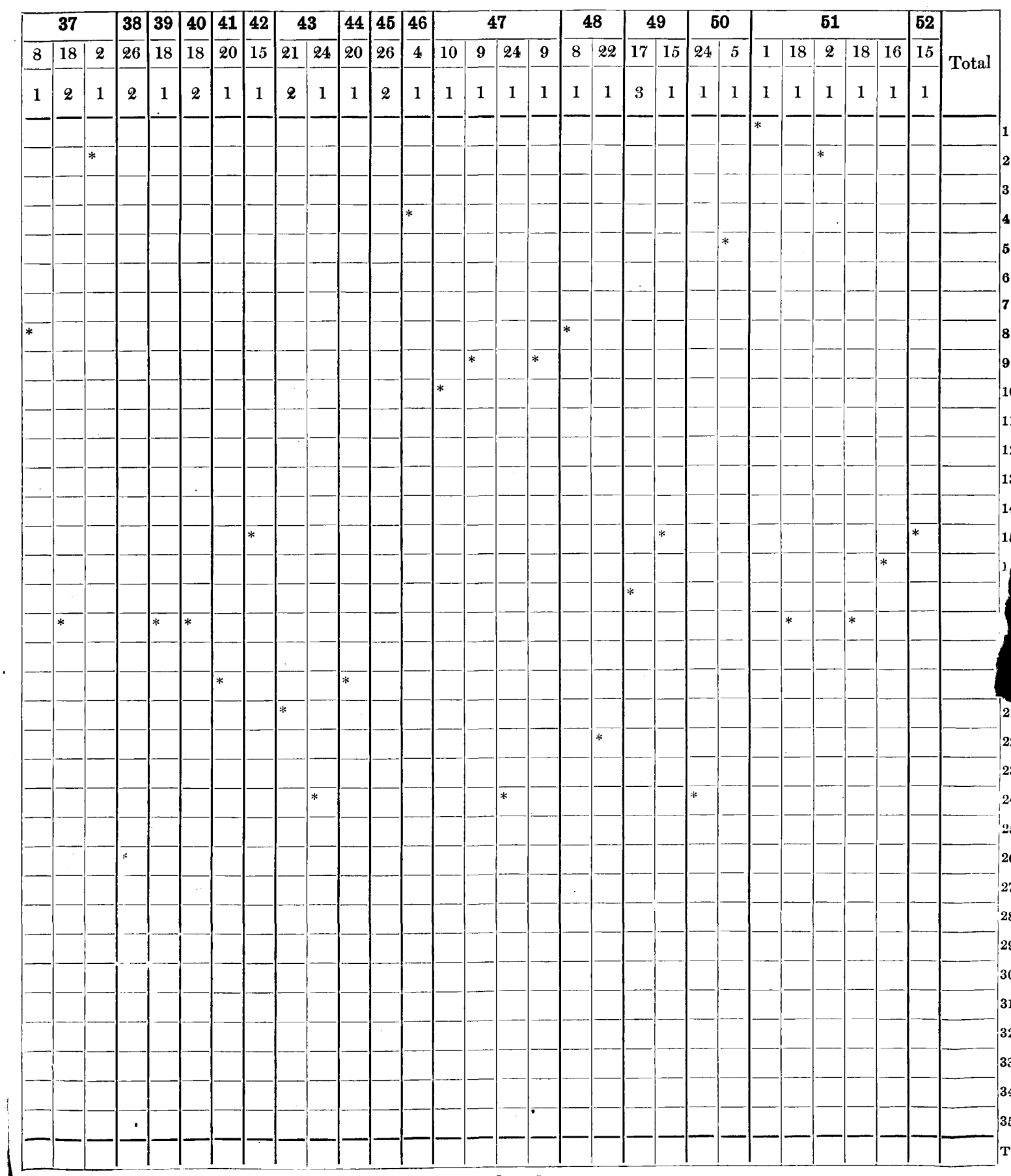


LEONARD DIAGNOSTIC TEST IN PUNCTUATION AND CAPITALIZATION

CLASS RECORD

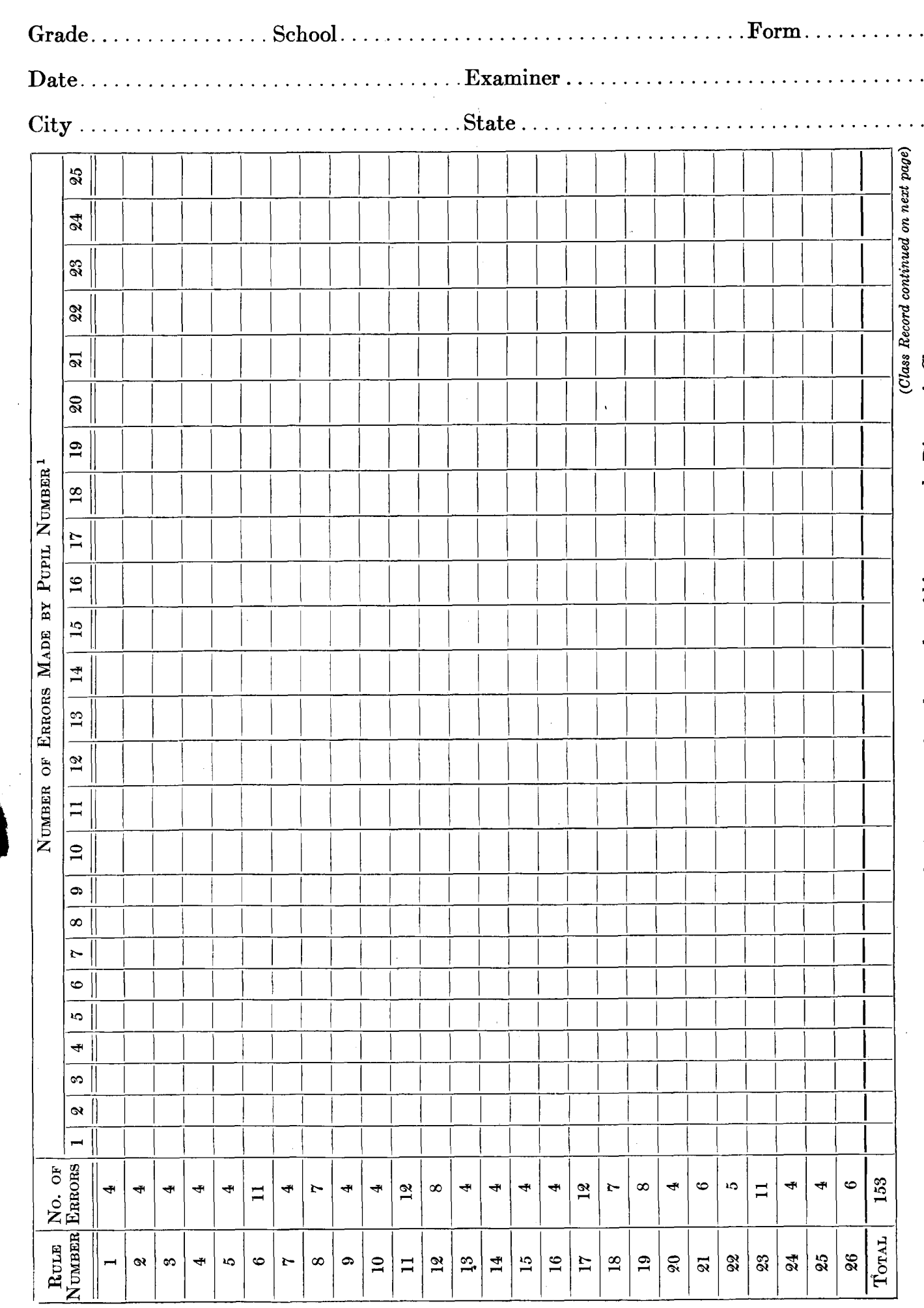

CLASS RECORD - Continued

Leonard Diagnostic Tes
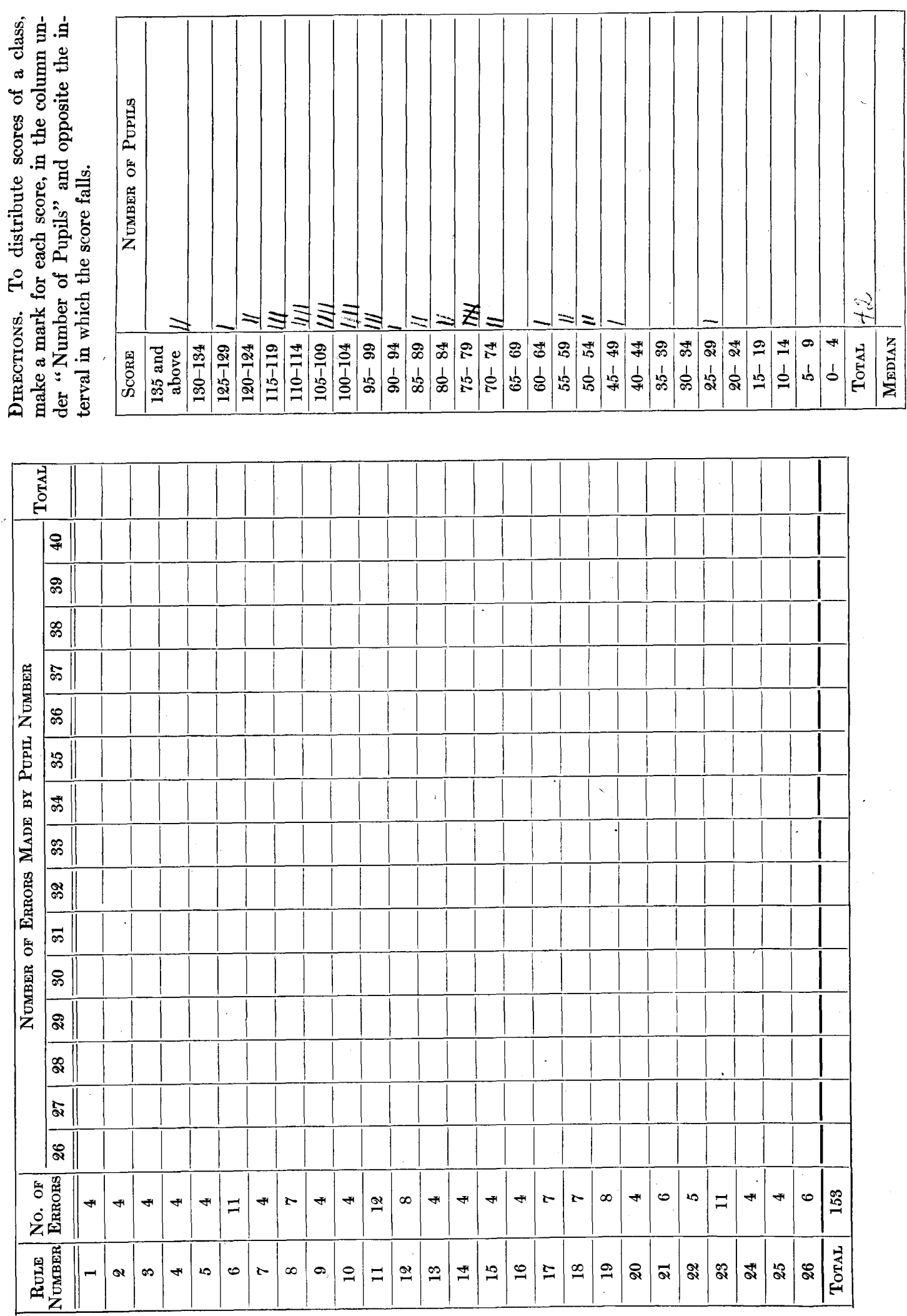


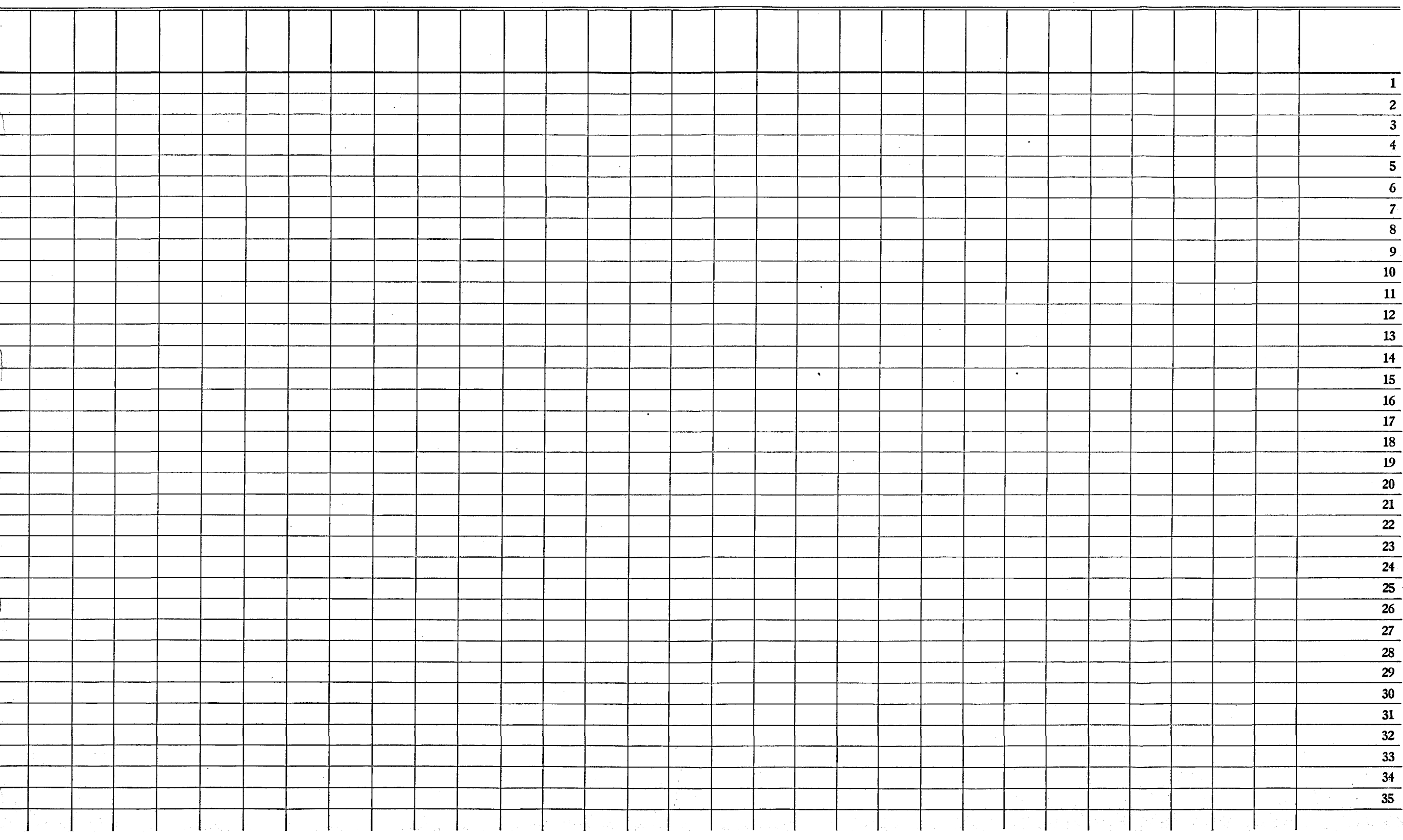

